Kabuzan, 1963 - Kabuzan V.M. Narodonaselenie Rossii v XVIII - pervoy polovine XIX veka [Population of Russia in the XVIII - first half of the XIX centuries]. M., 1963. 230 s. [in Russian].

Kamanin, 1890 - Kamanin Ivan. Statisticheskie dannyie o evreyah v Yugo-Zapadnom krae vo vtoroy polovine proshlogo veka (1765-1791 g.) [Censuses of the Jewish population in the Southwestern Territory in 1765-1791]// Arhiv Yugo-Zapadnoy Rossii, izdavaemyiy Vremennoyu komissiey dlya razbora drevnih aktov. Ch. 5. T. II. Vyip. I. K., 1890. S. 1-234. [in Russian].

Melnyk, 2015 - Melnyk I. Yevrei v etnosotsialnomu skladi naselennia Umanshchyny kintsia XVIII - pochatku XX st. [Jews in the ethno-social composition of the population of Uman region at the end of the XVIII - early XX century] // Naukovi zapysky Ternopilskoho natsionalnoho pedahohichnoho universytetu imeni Volodymyra Hnatiuka. Seriia: Istoriia. Ternopil, 2015. Vyp. 1. Ch. 3. S. 153-156. [in Ukrainian].

Melnyk, 2018a - Melnyk I. Yevreiske naselennia Umanskoho povitu naprykintsi XVIII - pochatku XX st. [Jewish population of Uman district in the late XVIII - early XX centuries: historical review]: istorychnyi ohliad // Eminak: naukovyi shchokvartalnyk. 2018. № 2. T. 2. S. 97-102. [in Ukrainian].

Melnyk, 2018b - Melnyk I.V. Yevreiske naselennia Umanshchyny naprykintsi XVIII - pochatku XX st. [Jewish population in Uman region at the end of the XVIII - early XX century]: avtoref. dys. ... k. ist. n. : 07.00.01. Istoriia Ukrainy, Chornomorskyi natsionalnyi universytet imeni Petra Mohyly. Mykolaiv, 2018. 18 s. [in Ukrainian].

Naulko, 1991 - Kabuzan V.M., Naulko V.I. Yevrei na Ukraini, v SRSR i v sviti: chyselnist i rozmishchennia [Jews in Ukraine, in the USSR and the world: their number and location] // Ukrainskyi istorychnyi zhurnal. 1991. № 6. S. 56-69. [in Ukrainian].

Yakobchuk, 2005 - Yakobchuk N.O. Prosopohrafichnyi portret Ivana Kamanina (1850-1921) [Prosopographic portrait of Ivan Kamanin (1850-1921)] // Arkhivy Ukrainy. 2015. Vyp. 4. S. 165-174. [in Ukrainian].

УДК 94(477.46)"1923/1925":299.2]:070

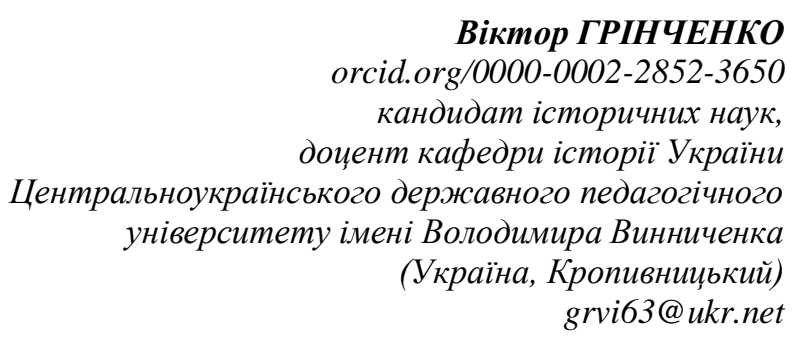

\title{
НЕПРИЙНЯТТЯ РЕЛІГІЙНИХ СВЯТ В РАННІЙ РАДЯНСЬКИЙ ПЕРІОД У ВІДОБРАЖЕННІ МІСЦЕВОЇ ПРЕСИ УМАНСЬКОЇ ОКРУГИ
}

У статті розглядається офіиійне ставлення партійних, державних, громадських структур в Уманській окрузі до релігійних свят у 1923-1925 рр. Проаналізовані відповідні матеріали вміщені на сторінках газети «Робітниче-селянська правда» - органу Уманського окружного комітету КП(б)У $і$ окрвиконкому Уманщини.

Зроблено висновок, щзо в Уманській окрузі, як і загалом в радянській Украйні у той період, відносно більш толерантне офіиійне ставлення до релігії поєднувалося із подальшим насадженням нетерпимості до неї. Це досить виразно виявлялося в неприйнятті релігійних свят та всього пов'язаного з ними $і$ вело до руйнації традиційних духовно-культурних цүінностей тих релігійних конфесій, які були представлені у цุьому регіоні.

Ключові слова: релігійні свята, Уманська округа, місиева преса, радянська влада, 1923-1925 роки, антирелігійна політика.

Viktor GRINCHENKO

Candidate of Historical Sciences,

Associate Professor of the Departament of Histori of Ukraine

Volodymyr Vynnychenko Central Ukrainian State Pedagogical University

(Ukraine, Kropyvnytskyi)

grvi63@ukr.net

\section{REJECTION OF RELIGIOUS HOLIDAYS IN THE EARLY SOVIET PERIOD IN THE REPRESENTATION OF THE LOCAL PRESS OF UMAN DISTRICT}

From the first years of Soviet rule in Ukraine, the Bolshevik Party actively fought against religious rites, 
sacraments, worship and holidays. On the eve of religious holidays, there was a significant increase in anti-religious propaganda. An important role in this was played by the official press, in particular, newspaper periodicals of various levels - from all-Ukrainian to regional publications. It published materials that covered the course of the leadership of the USSR and the union state in the field of religious policy, including directives on religious holidays, and reflected the practice of their implementation on the ground. The author of the article aimed to attract and analyze the sources that characterize the official rejection of religious holidays on the example of Uman district in the first half of the 1920 s.

The object of consideration were various publications related to this topic, published in 1923-1925 on the pages of the newspaper "Robitniche-selyanskaya Pravda" - a body of the Uman district committee of the CP(b)U and the district executive committee of Uman. The coverage period is generally characterized by more moderate manifestations of anti-religious propaganda, including on religious holidays, but this meant only a temporary change in Bolshevik tactics.

The materials analyzed in the article give grounds to state the following:

- During this period in Uman region there was a generally negative attitude to religious holidays by party, state institutions and subordinate public structures.

- A more effective method, compared to simply banning such holidays, was to displace them in various ways from daily life of urban and rural population, in particular, through the organization of "scientific propaganda" and the promotion of alternative forms of Soviet holiday rituals.

- There continued the practice of conducting anti-religious events, in particular large-scale antireligious campaigns aimed at forming in the minds of various social groups negative attitudes towards religious holidays and everything related to them. However, they were not entirely successful, as established religious traditions, especially of the rural population of Uman, often dominated. Some actions were aimed at ridiculing the content of religion and its rites, and their participants, mostly young people, did not always show due respect for the religious feelings of believers.

- The ostentatious refusal of working and educational groups of Uman region to celebrate religious holidays was encouraged, their work and studies were fully supported on these days, and appeals of civil and military assemblies to postpone holidays from Sunday to onto another day of the week associated with the official Soviet holiday of the proletarian revolution were spread.

In general, it can be stated that in Uman district at that time there was a tendency on the part of the authorities and public structures under their control to actively reject religious holidays and to displace them from everyday life of society. This ultimately led to the destruction of the traditional spiritual and cultural values of the religious denominations represented in the region.

Key words: religious holidays, Uman district, local press, Soviet authorities, 1923-1925, anti-religious policy

Постановка проблеми. 3 перших років утвердження радянської влади в Україні більшовицька партія вела активну боротьбу проти релігії і церкви. Особливого значення надавалося витісненню релігійного світогляду у масовій народній свідомості, викоріненню будь-яких проявів релігійності у житті суспільства. Важливе місце відводилося антирелігійній пропаганді, яка ставила на меті боротьбу з церковними обрядами, таїнствами, богослужіннями, святами. Перед релігійними святами відбувалося посилення такої пропаганди. Важливу роль в цьому відігравала офіційна преса, зокрема, газетна періодика різного рівня - від всеукраїнських до регіональних видань. Тут публікувалися матеріали, які висвітлювали курс політичного керівництва УСРР та союзної держави у сфері релігійної політики, зокрема директиви щодо ставлення до релігійних свят, і відображалася практика їхнього втілення на місцях.

Аналіз досліджень. В публікаціях сучасних вітчизняних дослідників, в контексті розгляду релігійної ситуації в УСРР у 1920-х роках, йдеться, серед іншого, про витіснення церковних і впровадження радянських свят, проведення антирелігійних святкувань і обрядів на радянський манер, вплив атеїстичної пропаганди у пресі на релігійну ситуацію в республіці. В цьому плані можна відзначити праці Л. Бабенко (Бабенко, 2010), О. Вітринської (Вітринська, 2016), Т. Гаєвської (Гаєвська, 2013), А. Киридон (Киридон, 2017), Ю. Матухно (Матухно, 2017), В. Силантьєва (Силантьєв, 2005), О. Тарапон (Тарапон, 2016), О. Чучаліна (Чучалін, 2019) та ін. Зокрема, А. Киридон зазначає, що в умовах 
формування соціалістичної дійсності відбувалася масштабна трансформація традиційної святково-обрядової культури, а головною функцією радянської обрядовості стало витіснення релігійності (Киридон, 2017: 17). Загалом же, існуючі публікації залишають можливості для продовження розгляду ряду питань, пов'язаних із ставленням до релігійних свят в регіональному контексті. Одним із значимих історичних джерел в цьому плані виступає місцева преса.

Мета статті. Ми маємо на меті висвітлити матеріали, що відобразили офіційне ставлення до релігійних свят, відповідно використавши для цього місцеву пресу Уманської округи першої половини 1920-х рр. Об'єктом аналізу стали публікації, пов'язані з цією тематикою, вміщені у 1923-1925 рр. на сторінках газети «Робітниче-селянська правда» - органу Уманського окружного комітету КП(б)У і окрвиконкому Уманщини (до 13 квітня 1924 р. вона мала статус газети повіткому КП(б)У і повітвиконкому Уманщини). Тексти, вміщені у ній, могли друкуватися як українською, так і російською мовами. Надалі у статті, для уникнення постійних повторів однієї і тієї ж назви, ми будемо просто вживати слово «газета».

Виклад основного матеріалу. Ранній період радянської влади в Україні характерний як радикальним втручанням держави у релігійне життя, так i відносно мирним ії співіснуванням з релігією. В тогочасній політиці наступу держави на релігійні конфесії в Україні можна виділити два етапи. Перший охоплює період 1919 - початку 1920-х років і характерний безкомпромісним натиском на позиції церкви із застосуванням методів «червоного терору» та воєнного часу. Другому періоду - від 1923 і до кінця 1920-х років - притаманні риси декларативної лібералізації державно-церковних відносин, формально відображені у партійних документах (Бабенко, 2010: 224). У залучених нами газетних джерелах прослідковуються певні риси такої лібералізації.

В період, що розглядається у статті, більш ефективним методом, порівняно із простою забороною релігійних свят, вважалося критичне висвітлення їхнього виникнення, доведення 3 наукових позицій неспроможності відображеного в них змісту, привнесення «червоних», «комуністичних», «комсомольських», пародійних новацій до традиційних релігійних ритуалів тощо. Зокрема, 11 січня 1924 р. в «Робітниче-селянській правді» було вміщено «Найближчі завдання по протирелігійній пропаганді», де серед іншого зазначалося, що у дні релігійних свят «треба поставити нові обряди», виявляючи всю беззмістовність старих обрядів, історію релігійних свят, порівнюючи їх 3 «поганськими святами», і створювати «веселі радянські свята» (Найближчі завдання, 1924). Також ставилося завдання організувати «наукову пропаганду шляхом проведення низки лекцій та бесід» (Найближчі завдання, 1924).

У тогочасній офіційній пресі, зокрема в місцевих газетах, які виходили в різних регіонах УСРР, не бракувало матеріалів, пов'язаних з антирелігійною пропагандою. Часто вони групувалися у рубрики з характерними назвами: «На боротьбу з релігійним дурманом», «Сторінка безбожника», «Єдиним фронтом проти релігії та безграмотності» тощо. На сторінках уманської «Робітничеселянської правди» переважно була представлена рубрика «Биймо бога». 
У 1923-1925 роках газета регулярно вміщувала публікації антирелігійного змісту, зокрема ті, що мали відношення до релігійних свят. Деякі з цих статей, авторами яких були популяризовані на загальносоюзному рівні письменники, публіцисти, друкувалися і в інших регіональних газетах. Це, зокрема, статті В. Брусяніна «Кому потрібні релігійні свята?» (Брусянін, 1925); I. Флєровського «Страдающий, умерший и воскресший...» (Флеровский, 1923), «Звідки пішли церковні свята?» (Флєровський, 1925) та ін.

Окремі публікації подібного характеру були підписані місцевими органами політпросвіти, маловідомими чи анонімними авторами (ймовірно, $\mathrm{i}$ місцевими). Серед них статті: «Праздник Пасхи и пасхальные обряды» (Политпросвет, 1923), «Страдающие и воскресающие боги и искупление ими людских грехов» (Новоселицкий, 1923), «Що таке свято різдва? (Св. Ген, 1924), «Проти Перуна й Христа - електрика й радіо» (Байдаченко, 1925), «Святкуймо не божі свята, а свята праці й перемоги» (Попова, 1925), «"Сейдер"» и "Тайная вечеря"» («Сейдер», 1923), «Как обманывают Иегову» (Как обманывают, 1923) та ін.

Можна із достатньою певністю стверджувати, що автором статті «Проти старого різдва» (Турган, 1924) був активний учасник «гуманського літпроцесу» і тодішній працівник редакції «Робітничо-селянської правди» Онопрій Турган, який пізніше став жертвою сталінських репресій (Поліщук, 2009). У цій своїй статті, опублікованій 24 грудня 1924 р., він, зокрема, давав рекомендації, як слід організувати червоне різдво. За його словами, в цей день хата-читальня, або сельбуд повинні бути переповнені селянами, особливо молоддю. В кожній хаті-читальні слід було вивісити лозунг «Ні один до церкви не йди!», прочитати лекцію про релігію та про іiі шкоду для трудящих, почитати цікаву книжку, влаштувати хоровий спів і т. п. Всі присутні на святі повинні були оголосити «страйк старому різдву» (Турган, 1924). У квітні 1925 р. в газетній замітці про літературну студію «Плугу» при Уманському агротехнікумі згадано дві п’єси, одну з яких («Жовтневе різдво») було «поставлено на селі» (Літстудія, 1925).

Концентрованим проявом подібних форм роботи виступали в той час антирелігійні кампанії - «антиріздвяні» та «антипасхальні». Першим досвідом розгортання такої роботи на селі стало проведення «комсомольського Різдва» 1922 р. (Киридон, 2017). А наприкінці березня - на початку квітня 1923 р. вже проводилася «очередная антирелигиозная кампания», до якої також долучилися місто Умань і Уманська округа. На цей раз це вже була «комсомольська Пасха» (Пасхальная кампания, 1923; К Комсомольской Пасхе, 1923).

Пізніше у звіті про неї, зокрема, зазначалося: «В союзах с преобладающим составом рабочих-евреев проводились доклады на тему: «Еврейская пасха», а с преобладающим составом русских: «Пасха и пасхальные обряды»»» (Работа агитпропа, 1923). В Умані 1 та 7 квітня були проведені вечори антирелігійної пропаганди. На одному із них, що відбувся 1 квітня, «рабочие-евреи вынесли постановление о том, чтобы просить Окрисполком передать бывшую хоральную синагогу под рабочий клуб» (Работа агитпропа, 1923). Аналогічні резолюції виносилися на деяких інших зібраннях. В Уманській окрузі кампанія проводилася у селах, де малися комуністичні 
партячейки. Всього відбулося 71 зібрання, на яких були присутні понад 10 тис. чоловік (Работа агитпропа, 1923).

Результати проведеної роботи оцінювались неоднозначно. Констатувалося, що кампанія викликала великий інтерес і підтримку з боку трудящих як міста, так і села. Поряд із цим зазначалося, що ударний характер кампанії не в повній мірі відповідав очікуваним результатам, що багато ячейок, особливо в окрузі, не зрозуміли поставлених завдань, а деякі з комсомольських ячейок «своими революционными действиями во время проведения кампании подрывали всю начатую работу» (Работа агитпропа, 1923).

Ця антирелігійна кампанія грунтовно висвітлювалася у місцевій пресі Уманщини. Наведемо деякі характерні приклади того, як вона проводилася. Так, 24 березня в передовій статті «Робітниче-селянської правди» під назвою «К антирелигиозной пропаганде в пасхальные дни» серед іншого зазначалося: «Сейчас по всей Республике сознательные рабочие и крестьяне, по своей собственной инициативе, ведут поход против религии: закрываются по приговорам сел церкви, а вместо них открываются детдома; рабочие повсеместно выносят постановления об отмене религиозных празднеств и о переносе дня отдыха с воскресенья на какой либо другой день недели. Это говорит за то, что антирелигиозная пропаганда, ведомая партией, нашла широкий отклик в крестьянских и рабочих, даже беспартийных массах. Эту кампанию надо усилить и в пасхальные дни, когда христианские и иудейские попы приступят к традиционной комедии, имеющей целью отравлять воображение широких масс, особенно юношества своим лживым ядом религиозного дурмана...» (К антирелигиозной пропаганде, 1923).

А 29 березня газета писала: «Подготовка к празднованию Комсомольской пасхи вызвала сильное оживление в горорганизации КСМУ... В городе комсомольская пасха ставит своей целью борьбу з еврейскими религиозными традициями, приуроченными к Пасхе» (К Комсомольской пасхе, 1923).

Налаштований на «рішучу антирелігійну пропаганду на пасхальні свята» комнезам села Громи постановив в суботу, коли по церквах буде йти пасхальна служба, «зробити виставу, на яку повинні з'явитись всі члени комнезаму», а тих, хто не з'явиться, буде виключено з організації (Дідусь, 1923). В селі Ксендзівка була заслухана доповідь «Пасха та іiі обряди» i, за словами дописувача, з тих дискусій, які виникли після неї, видно було, що вплив релігії серед населення «досить похитаний» [Фіалко, 1923]. Після проведення в селі Танське мітингу та вистави «Геть бога» «набожні бабки» говорили пошепки, що в Танському «появився антихрист» (Антирелігійна пропаганда, 1923).

В селі Підвисоке було зроблено доповідь про походження пасхи та іiі обрядів і влаштовано виставу «Геть від бога». Запросили також і священника, якому запропонували захищати релігію. Згідно слів дописувача, той сказав: «Науки я не опровергаю, а від захисту релігії зрікаюсь», - і нічого не відповів на поставлене йому питання: чому бог не карає артистів, що грають цю виставу (Макуха, 1923). 8 квітня, в день православної пасхи, відбувся релігійний диспут у селі Нестерівка, учасники якого в кінцевому рахунку прийшли до висновку, що «докази існування бога не мають під собою абсолютно ніякого грунту...» 
(Безбожник, 1923). В селі Княжики місцевий комнезам організував у пасхальну неділю виселення священника із церковної хати та спалення ікон під спів Інтернаціоналу (Боротьба комнезаму, 1923). Члени цього комнезаму «знесли на майдан свої образи і попалили, якраз в той час коли баби та решта несвідомих селян святили паски» (Лабенський, 1924).

У передовій статті «Закрепим победу» 4 квітня газета писала, що на антирелігійному вечорі робітників Умані, який 31 березня відбувся у клубі поліграфістів, «еврейских безбожников было так много, что клуб не мог вместить всех желавших принять участие в пролетарском сейдере» (Закрепим победу, 1923). Наголошувалося, що за прикладом робітників Мінська, Гомеля, Бердичева, Києва, Харкова, Одеси та ін., робітники Умані не обмежились тим, що $з$ великим інтересом прослухали антирелігійну доповідь й демонстративно скуштували заборонені коржики, а «перешли в наступление на религиозном фронте и постановили превратить хоральную синагогу в пролетарский театр», i при цьому «никто не высказался против» (Закрепим победу, 1923). На цьому ж вечорі були представлені деякі «антирелигиозные инсценировки, каррикатурно изображающие обряды пасхи» (Вечер в клубе, 1923).

На інших подібних зібраннях в Умані у рамках цієї кампанії підтримка не завжди була такою одностайною. На зборах членів спілок працівників освіти і мистецтва було одноголосно схвалено передати один із соборів, костел і дві хоральні синагоги Умані під культурно-просвітницькі установи, а Пасху названо «праздником являющимся орудием угнетения для господствующих классов» (Церкви, 1923). Збори медичних працівників майже одноголосно (шість чоловік утримались) прийняли резолюцію, в якій пропонували передати хоральну синагогу під робітничий театр, і заявили, що «праздник Пасхи и вообще праздники всех религий являются наследием проклятого прошлого...» (Медсанработники, 1923). На зібранні транспортників і будівельників докази доповідача про пасху та пасхальні обряди правильними визнало «подавляющее большинство» присутніх (На общем собрании, 1923). На зборах харчовиків за «антирелигиозную резолюцию» голосували лише «около 40 человек», а інші утримались (Только 40 пищевиков, 1923). 7 квітня на вечорі антирелігійної пропаганди в театрі «Комуна» «антирелигиозная резолюция» була прийнята майже одноголосно (лише троє чоловік утримались і один був проти) (Вечер антирелигиозной пропаганды, 1923).

Розгляд досить значної кількості відповідних публікацій у «Робітничеселянській правді» дає підстави вважати, що газета прагнула представити насамперед успіхи в антирелігійній пропаганді, в тому числі й у формуванні серед населення негативного ставлення до релігійних свят, однак поряд з цим вона висвітлювала й існуючі проблеми у цьому питанні.

Наприклад, в одній із газетних заміток описано ситуацію в селі Побійна, де під вечір свята пасхи мала проводитись «антирелігійна пропаганда в хатічитальні», однак на ній не було жодного члена місцевого комнезаму. А тим часом, як зазначав автор замітки, «у той вечір куркулі, глузуючи казали, що за комнезамами не можна було протиснутись у церкву» [Сідоренко, 1923].

У селі Тальянки перед Різдвом на свят-вечір було заплановано провести 
вечір антирелігійної пропаганди, але на нього майже ніхто із селян не з'явився. Прийшли кілька комсомольців, комуністів та вчителів. Не було навіть нікого із комнезаму та сільради. «Значить і для них попівські святощі дорожчі, ніж пролетарські», - робив висновок дописувач (Антирелігійна пропаганда, 1924). Ситуацію спробували виправити на другий день. На цей раз зібралося до ста чоловік молоді - хлопців від 8 до 20 років, а з сільських дівчат не було нікого (Антирелігійна пропаганда, 1924). Подібна ситуація склалася в селі Бабанка, де на різдвяні свята в клубі читалися лекції на антирелігійні теми, які викликали зацікавленість молоді. Однак, за словами автора замітки, там не було «ні одної селянської дівчини», і ним робився висновок, що жіноцтво «ще знаходиться в лапах релігійного дурману» (Робітник, 1924).

Протилежна картина мала місце в селі Заячківка, в якому, виходячи зі слів автора замітки, «наші комнезамці навіть жінок перевернули на свій лад» (Юненко, 1925). При цьому вказувалося, що вони «цілком порвали зв’язок 3 релігійними забобонами», похорони і весілля справляють «без попа», в їхніх хатах «замісць святих богомазів висять портрети революційних діячів», вони не визнають релігійних свят і, зокрема на різдво, працювали (Юненко, 1925).

Ряд газетних публікацій було присвячено висвітленню показної відмови різних колективів Уманщини відзначати релігійні свята та демонстративним пропозиціям про перенесення днів відпочинку з неділі на інший день тижня.

В цьому плані зазначимо, що в ранній період радянської влади календар святкових та неробочих днів не був усталеним, він змінювався в різні роки і в різних регіонах. Більшовики встановили ряд нових загальнодержавних свят, а 3 тих, які існували ще за царського режиму, визнавали лише Новий рік. Поряд із цим існувала певна кількість неробочих днів, які вважалися днями відпочинку. До них належали традиційні, найбільш значимі релігійні свята. Порівняно 3 дореволюційними часами таких днів вже стало явно менше, але відмінити їх зовсім радянська влада не наважилась, і вони, в більшій чи меншій кількості, проіснували до кінця 1920-х років.

В період, який розглядається у статті, зокрема станом на березень 1924 р., табель свят і неробочих днів в Київській губернії (до якої на той час входила Уманська округа) мав наступний вигляд: 1 січня - Новий рік (свято), 6 січня - Водохреща (день спочинку), 22 січня - День 9-го Січня 1905 р. (свято), 11 березня - Роковини смерті Т. Шевченка (свято), 12 березня Скинення царату (свято), 18 березня - День Паризької Комуни (свято), 25 березня - Благовіщення (день спочинку), 27-28 квітня - Паска (день спочинку), 1 травня - День III-го Інтернаціоналу (свято), 5 червня - Вознесіння (день спочинку), 16 червня - Духів день (день спочинку), 6 липня - День прийняття Конституції Союзу РСР (свято), 6 серпня - Преображення (день спочинку), 15 серпня - Успіння (день спочинку), 7 листопада - День Пролетарської Революції (свято), 25-26 грудня - Різдво (день спочинку) (Табель, 1924). Як можна бачити, дні державних свят переведені тут на календар нового стилю, а неробочі дні, пов'язані із православними релігійними святами, подані за старим стилем.

Наприкінці березня 1923 р. в Умані на загальних зборах членів 
партячейки, співробітників і червоноармійців штабу корпусу розглядалося питання про свято Пасхи і релігійні обряди. У прийнятій резолюції було, зокрема, сказано: «Признавая за праздниками только хозяйственный характер, нормирующий труд и заключающийся в чередовании дней отдыха и труда, Мы, вчерашние рабочие и крестьяне, требуем от Соввласти, дабы она днем отдыха для пролетариата считала не воскресенье, а среду - день победоносного восстания русского пролетариата и воскресения его к новой, свободной и светлой жизни» (Рабкор, 1923). Очевидно, що тут малося на увазі 7 листопада 1917 року, яке припало на середу. Подібне рішення було ухвалено також і на засіданні комітету незаможних селян у селі Громи - перенести святкування на будній день, а саме на середу (Дідусь, 1923). У квітні 1924 р. працівники Уманської друкарні за пропозицією свого партосередку вирішили замінити релігійне свято Пасхи святкуванням у другий дня травня та закликали інших робітників наслідувати їхній приклад (Робітниче життя, 1924).

В газеті відображалися також і окремі проблемні ситуації, які виникали у деяких трудових колективах щодо тлумачення дат відзначення релігійних свят та пов'язаних з ними неробочих днів.

Наприклад, 16 травня 1923 р. у замітці «Благочестивые маслобойщики» піддавалися критиці «рабочие-маслобойщики Загороднего района» за те, що вирішили святкувати і в суботу, і в неділю, а замість зайвого вихідного дня працювати в інші дні не вісім, а дев’ять годин. Дописувач наголосив: «Не беда, что кодекс законов о труде этого не разрешает: зато и русский и еврейский бог будут довольны. Очевидно, религиозный дурман, изгнанный из голов других рабочих, переместился в головы Загородних маслобойщиков» (Бляу, 1923).

Коли на загальному зібранні робітників Тальнівської цукроварні 21 грудня 1923 р. було поставлене питання про те, коли святкувати різдво Христове - по старому чи по новому стилю, то «значна більшість» присутніх пропонувала святкувати по старому стилю. Автор замітки зазначав, що це показує, наскільки провінційні робітники ще відстають від своїх міських товаришів, та намагався пояснити, що перехід у святкуванні різдва на новий стиль «релігії не зачіпає», бо це є лише «підрівнення» церковного календаря (Соловйов, 1924).

В одній із газетних заміток піддавалися критиці службовці Оратівського райвиконкому, які в січні 1925 р., на день старого Різдва, не вийшли на роботу. Автор констатував, що не тільки «по темних селах релігійний дурман панує, але навіть в радянських установах», та наголошував, що це непередбачене свято «було улаштовано службовцями тілько в межах свого Райвиконкому» (Бондарчук, 1925). За подібне критикували в газеті і працівників Зубрицького комнезаму. Дописувач зазначав: «Новий рік в Радянській Федерації є святом і навіть обов'язковим для таких організацій, як КНС. Наш КНС в це свято якраз працював, підриваючи цим свій авторитет серед темного населення. А зараз збирається ще й святкувати релігійні свята» (Сиротюк, 1924).

Іноді до роботи в релігійні свята селян змушували об'єктивні обставини. Так селькор із села Дзенгелівка у вересні 1923 р. писав, що «дощі цього літа багатьох селян довели до безвірництва», і вони поспішають змолотити хліб, не зважаючи на релігійні свята (Відгадай, 1923). 
Неприйняття релігійних свят досить активно насаджувалося у навчальних закладах. Наприклад, 25 березня 1923 р. на загальних зборах учнів уманської Пролетарської школи було прийнято постанову взяти участь у святкуванні комсомольської пасхи, з'явитись 1 квітня на демонстрацію, а у дні свят продовжувати заняття. До тих, хто не з'явиться на демонстрацію та на заняття у дні свят, було ухвалено «принять самые суровые меры» аж до «занесения на черную доску» та розгляду у товариському суді (Пролетшкола, 1923).

В одній із заміток окреслювалася проблема численних пропусків учнями занять у сільських школах, в тому числі й через релігійні свята. Так селькор Вольська зазначала: «Треба запам'ятати селянам, щоб діти їх були не менше 8 місяців у школі. Для цього восени треба посилати їх вчасно й не затримувати їх дома під час зимових релігійних свят» (Вольська, 1925). В селі Кам'янече, щоб перешкодити відвідуванню учнями церкви, педагогічна рада школи ухвалила перенести навчальний день на неділю, коли в церкві відбувається служба. За словами автора замітки, цей захід мав позитивні наслідки: більшісь учнів зосталася «під впливом школи» (Деменний, 1923).

Висновки. Залучені та проаналізовані у статті газетні матеріали дають підстави стверджувати наступне:

- У 1923-1925 pp. на Уманщині зберігалося загалом негативне ставлення до релігійних свят 3 боку партійних, державних інституцій та підпорядкованих їм громадських структур.

- Більш ефективним методом, порівняно із простою забороною таких свят, вважалося витіснення їx різними шляхами із повсякденного життя міського та сільського населення, зокрема, через організацію «наукової пропаганди» i популяризацію альтернативних форм радянської святкової обрядовості.

- Продовжувалася практика проведення антирелігійних заходів, зокрема масштабних антирелігійних кампаній, спрямованих на формування у свідомості різних соціальних верств негативного ставлення до релігійних свят $\mathrm{i}$ всього пов'язаного з ними. Однак вони не у всьому були успішними, оскільки усталені релігійні традиції, особливо сільського населення Уманщини, досить часто домінували. Деякі дійства були спрямовані на висміювання змісту релігії та іiі обрядів, а їхні учасники, переважно молодь, не завжди демонстрували належну повагу до релігійних почуттів віруючих.

- Заохочувалася показна відмова трудових і навчальних колективів Уманщини відзначати релігійні свята, всіляко підтримувалася їхня робота i навчання у ці дні; поширювалися заклики цивільних і військових зібрань щодо перенесення днів відпочинку з неділі на інший день тижня, який асоціювався 3 офіційним радянським святом пролетарської революції.

Отже, в Уманській окрузі, як і загалом в радянській Україні у той період, відносно більш толерантне офіційне ставлення до релігії поєднувалося із подальшим насадженням нетерпимості до неї. Це досить виразно виявлялося в неприйнятті релігійних свят та всього пов'язаного з ними і вело до руйнації традиційних духовно-культурних цінностей тих релігійних конфесій, які були представлених у цьому регіоні. 


\section{СПИСОК ВИКОРИСТАНИХ ДЖЕРЕЛ І ЛІТЕРАТУРИ}

«Сейдер», 1923 - «Сейдер» и «Тайная вечеря»// Робітниче-селянська правда. 1923. 22 березня. № 63. С. 2. Підпис: Ф. Н.

Антирелігійна пропаганда, 1923 - Антирелігійна пропаганда в с. Танському // Робітниче-селянська правда. 1923. 11 квітня. № 78. С. 3. Підпис: В. Б.

Антирелігійна пропаганда, 1924 - Антирелігійна пропаганда в с. Тальянках // Робітниче-селянська правда. 1924. 16 січня. № 9. С. 2. Підпис: М.

Бабенко, 2010 - Бабенко Л. Особливості антирелігійної пропаганди 1920-х років та їі альтернативи // Філософські обрії. 2010. № 24. С. 222-235. URL: http://dspace.nbuv.gov.ua/bitstream/handle/123456789/25951/18Babenko.pdf?sequence $=1$

Байдаченко, 1925 - Байдаченко Г. Проти Перуна й Христа - електрика й радіо // Робітниче-селянська правда. 1925. 31 грудня. № 298. С. 3.

Безбожник, 1923 - Релігійна дискусія в с. Нестерівці // Робітниче-селянська правда. 1923. 29 квітня. № 94. С. 2. Підпис: Безбожник.

Бляу, 1923 - Бляу Д. Благочестивые маслобойщики // Робітниче-селянська правда. 1923. 16 травня. № 107. С. 4. Бондарчук, 1925 - Релігійний дурман та бабські забобони // Робітниче-селянська правда. 1925. 5 лютого. № 28. С. 2. Підпис: Бондарчук.

Боротьба комнезаму, 1923 - Боротьба комнезаму с. Княжиків з релігійними забобонами // Робітниче-селянська правда. 1923. 29 квітня. № 94. С. 2. Підпис: Б.

Брусянін, 1925 - Брусянін В. Кому потрібні релігійні свята? // Робітниче-селянська правда. 1925.12 квітня. № 83. C. 1 .

Вечер антирелигиозной пропаганды, 1923 - Вечер антирелигиозной пропаганды в театре «Коммуна» // Робітниче-селянська правда. 1923. 11 квітня. № 78. С. 3. Підпис: Д.

Вечер в клубе, 1923 - Вечер в клубе полиграфистов // Робітниче-селянська правда. 1923. 4 квітня. № 74. С. 2. Підпис: Д.

Відгадай, 1923 - Без бога хліб матимеш, а з богом торбу чіплятимеш // Робітниче-селянська правда. 1923. 15 вересня. № 209. С. 3. Підпис: Селькор Відгадай.

Вітринська, 2016 - Вітринська О. В. Політика радянської влади щодо юдаїзму в Україні в 1921-1929 роках. Дис... канд. іст. наук. Полтава, 2016. 254 с. URL: https://shron1.chtyvo.org.ua/Vitrynska_Olena/Polityka radianskoi_vlady_schodo_iudaizmu_v_Ukraini_v_1921-1929 rokakh.pdf

Вольська, 1925 - Не держіть учнів вдома в релігійні свята // Робітниче-селянська правда. 1925.19 грудня. № 290. С. 3. Підпис: Селькорка Вольська.

Гаєвська, 2013 - Гаєвська Т. Державні радянські свята: історико-культурологічний аспект // Культурологічна думка. 2013. № 6. С. 153-159. URL: http://nbuv.gov.ua/UJRN/Kultdum_2013 $6 \_21$

Деменний, 1923 - Школа с. Кам’янечого бореться з релігійними забобонами // Робітниче-селянська правда. 1923. 14 квітня. № 81. С. 2. Підпис: Деменний.

Дідусь, 1923 - Антирелігійна пропаганда на пасхальні свята в с. Громах // Робітниче-селянська правда. 1923. 4 квітня. № 74. С. 2. Підпис Дідусь.

Єв. Ген, 1924 - Що таке свято різдва? // Робітниче-селянська правда. 1924. 25 грудня. № 225. С. 2. Підпис: Єв. Ген.

Закрепим победу, 1923 - Закрепим победу // Робітниче-селянська правда. 1923. 4 квітня. № 74. С. 1.

К антирелигиозной пропаганде, 1923 - К антирелигиозной пропаганде в пасхальные дни // Робітниче-селянська правда. 1923. 24 березня. № 65. С. 1.

К Комсомольской пасхе, 1923 - К Комсомольской пасхе // Робітниче-селянська правда. 1923. 29 березня. № 69. C. 3 .

Как обманывают, 1923 - Как обманывают Иегову // Робітниче-селянська правда. 1923. 1 квітня. № 72 . С. 2.

Киридон, 2017 - Киридон А. М. Індоктринація радянськості: обрядово-святковий канон як маркер формування атеїзованого суспільства (1920-1930-і рр.) // Уманська старовина. $2017 . \quad$ Випуск 3. С. 5-20. URL: http://www.irbis-nbuv.gov.ua/cgi-

bin/irbis_nbuv/cgiirbis_64.exe?I21DBN=LINK\&P21DBN=UJRN\&Z21ID=\&S21REF=10\&S21CNR=20\&S21STN=1 \&S21FMT=ASP_meta\&C21COM=S\&2_S21P03=FILA=\&2_S21STR=umanst_2017_3_3

Лабенський, 1924 - С. Княжики // Робітниче-селянська правда. 1924. 6 серпня. № 107. С. 3. Підпис: Лабенський.

Літстудія, 1925 - Літстудія «Плугу» при Уманськім Агротехнікумі // Робітниче-селянська правда. 1925. 15 квітня. № 85. С. 2. Підпис: П. К.

Макуха, 1923 - Боротьба з релігійними забобонами в с. Підвисокому // Робітниче-селянська правда. 1923. 29 квітня. № 94. С. 2. Підпис: Макуха.

Матухно, 2017 - Матухно Ю. О. Проблема класифікації радянських свят у перше пореволюційне десятиліття // Наукові праці історичного факультету Запорізького національного університету. 2017. Вип. 48. С. $139-142$. URL: http://www.irbis-nbuv.gov.ua/cgi-

bin/irbis_nbuv/cgiirbis_64.exe?C21COM=2\&I21DBN=UJRN\&P21DBN=UJRN\&IMAGE_FILE_DOWNLOAD=1\&I mage_file_name=PDF/Npifznu_2017_48_27.pdf 
Медсанработники, 1923 - Медработники не отстают // Робітниче-селянська правда. 1923. 6 квітня. № 76. С. 2. На общем собрании, 1923 - На общем собрании транспортников и строителей // Робітниче-селянська правда. 1923. 31 березня. № 71. С. 3.

Найближчі завдання, 1924 - Найближчі завдання районних комісій по протирелігійній пропаганді // Робітничеселянська правда. 1924. 11 січня. № 7. С. 3.

Новоселицкий, 1923 - Новоселицкий Ф. Страдающие и воскресающие боги и искупление ими людских грехов // Робітниче-селянська правда. 1923. 20 березня. № 61. С. 2.

Пасхальная кампания, 1923 - Пасхальная кампания // Робітниче-селянська правда. 1923. 28 березня. № 68. С. 3. Политпросвет, 1923 - Праздник Пасхи и пасхальные обряды // Робітниче-селянська правда. 1923.20 березня. № 61. С. 2. Підпис: Политпросвет Укома КСМ.

Поліщук, 2009 - Поліщук В. Онопрій Турган - журналіст і письменник. URL: https://umanliteratura.ucoz.ua/news/ v_polishhuk_onoprij_turgan_zhurnalist_i_pismennik/2010-12-20-256

Попова, 1925 - Попова О. Святкуймо не божі свята, а свята праці й перемоги // Робітниче-селянська правда. 1925. 12 квітня. № 83. С. 2.

Пролетшкола, 1923 - Пролетшкола против бога // Робітниче-селянська правда. 1923. 28 березня. № 68. С. 2.

Рабкор, 1923 - Будем бороться с религией как и с вооруженным врагом // Робітниче-селянська правда. 1923. 3 квітня. № 73. С. 3. Підпис: Рабкор К.

Работа агитпропа, 1923 - Работа агитпропа в апреле // Робітниче-селянська правда. 1923. 9 травня. № 101 . С. 3. Робітник, 1924 - Освіту жінці на селі // Робітниче-селянська правда. 1924. 8 лютого. № 18. С. 3. Підпис: Робітник.

Робітниче життя, 1924 - Робітниче життя // Робітниче-селянська правда. 1924. 23 квітня. № 48. С. 3.

Силантьєв, 2005 - Силантьєв В. І. Влада і православна церква в Україні (1917-1930 рр.). Автореф. дис... докт. іст. наук. Харків, 2005. 46 с.

Сиротюк, 1924 - Зубрицький КНС не порвав ще з релігією // Робітниче-селянська правда. 1924. 5 січня. № 4. С. 2. Підпис: Сиротюк.

Сідоренко, 1923 - Сідоренко 3. Необхідна чистка комнезаму с. Побійної // Робітниче-селянська правда. 1923. 19 квітня. № 85. С. 2.

Соловйов, 1924 - Соловйов Д. Небажане явище // Робітниче-селянська правда. 1924. 16 січня. № 9. С. 2.

Табель, 1924 - Табель свят і неробочих днів. Обов’язкова постанова Київського губвиконкому № 49 від 19 березня 1924 року // Вістник Київського губвиконкому. 1924. 2 квітня. № 14. С. 2.

Тарапон, 2016 - Тарапон О. Державні свята в Україні 1920-1930-х рр. як засіб формування радянських політичних цінностей // Актуальні питання гуманітарних наук: міжвузівський збірник наукових праць молодих вчених Дрогобицького державного педагогічного університету імені Івана Франка. Дрогобич, 2016. Вип. 15. C. 96-102. URL: http://nbuv.gov.ua/UJRN/apgnd_2016_15_13

Только 40 пищевиков, 1923 - Только 40 пищевиков не одурачены религией // Робітниче-селянська правда. 1923. 31 березня. № 71. С. 3.

Турган, 1924 - Турган О. Проти старого різдва // Робітниче-селянська правда. 1924. 24 грудня. № 224. С. 2. Фіялко, 1923 - Фіялко С. Антирелігійна пропаганда в с. Ксендзівці // Робітниче-селянська правда. 1923. 19 квітня. № 85. С. 2.

Флеровский, 1923 - Флеровский И. Страдающий, умерший и воскресший... // Робітниче-селянська правда. 1923. 6 квітня. № 76. С. 3.

Флєровський, 1925 - Флєровський І. Звідки пішли церковні свята // Робітниче-селянська правда. 1925. 10 квітня. № 81. С. 2.

Церкви, 1923 - Церкви, костелы, синагоги - под клубы и театры // Робітниче-селянська правда. 1923. 6 квітня. № 76. С. 2 .

Чучалін, 2019 - Чучалін О. П. Вплив атеїстичної пропаганди радянської преси на релігійну ситуацію в УСРР у 1920-1930-ті pp. // Гілея: науковий вісник. 2019. Випуск 142(1). С. 182-188. URL: http://www.irbisnbuv.gov.ua/cgi-

bin/irbis_nbuv/cgiirbis_64.exe?I21DBN=LINK\&P21DBN=UJRN\&Z21ID=\&S21REF=10\&S21CNR=20\&S21STN=1 \&S21FMT=ASP_meta\&C21COM=S\&2_S21P03=FILA=\&2_S21STR=gileya_2019_142(1)_ 39

Юненко, 1925 - Юненко С. Наш КНС // Робітниче-селянська правда. 1925. 16 січня. № 9. С. 3.

\section{REFERENCES}

«Seider», 1923 - «Seider» y «Tainaia vecheria» ["Seider" and "The Last Supper"] // Robitnyche-selianska pravda. 1923. 22 bereznia. № 63. S. 2. Pidpys: F. N. [in Ukrainian].

Antyrelihiina propahanda, 1923 - Antyrelihiina propahanda v s. Tanskomu [Anti-religious propaganda in the village of Tanske] // Robitnyche-selianska pravda. 1923. 11 kvitnia. № 78. S. 3 Pidpys: V. B. [in Ukrainian].

Antyrelihiina propahanda, 1924 - Antyrelihiina propahanda v s. Taliankakh [Anti-religious propaganda in the village of Talianki] // Robitnyche-selianska pravda. 1924. 16 sichnia. № 9. S. 2. Pidpys: M. [in Ukrainian].

Babenko, 2010 - Babenko L. Osoblyvosti antyrelihiinoi propahandy 1920-kh rokiv ta yii alternatyvy [Features of antireligious propaganda of the 1920s and its alternatives] // Filosofski obrii. 2010. № 24. S. 222-235. URL: http://dspace.nbuv.gov.ua/bitstream/handle/123456789/25951/18-Babenko.pdf?sequence=1 [in Ukrainian]. 
Baidachenko, 1925 - Baidachenko H. Proty Peruna y Khrysta - elektryka y radio [Against Perun and Christ electricity and radio] // Robitnyche-selianska pravda. 1925. 31 hrudnia. № 298. S. 3 [in Ukrainian].

Bezbozhnyk, 1923 - Relihiina dyskusiia v s. Nesterivtsi [Religious discussion in the village of Nesterivka] // Robitnyche-selianska pravda. 1923. 29 kvitnia. № 94. S. 2. Pidpys: Bezbozhnyk [in Ukrainian].

Bliau, 1923 - Bliau D. Blahochestyvыe masloboishchyky [Pious chippers] // Robitnyche-selianska pravda. 1923. 16 travnia. № 107. S. 4 [in Russian].

Bondarchuk, 1925 - Relihiinyi durman ta babski zabobony [Religious dope and women superstitions] // Robitnycheselianska pravda. 1925. 5 liutoho. № 28. S. 2. Pidpys: Bondarchuk [in Ukrainian].

Borotba komnezamu, 1923 - Borotba komnezamu s. Kniazhykiv z relihiinymy zabobonamy [The struggle of the komnezam of the village of Knyazhyky with religious prejudices] // Robitnyche-selianska pravda. 1923. 29 kvitnia. № 94. S. 2. Pidpys: B. [in Ukrainian].

Brusianin, 1925 - Brusianin V. Komu potribni relihiini sviata? [Who needs religious holidays?] // Robitnyche-selianska pravda. 1925. 12 kvitnia. № 83. S. 1 [in Ukrainian].

Vecher antyrelyhyoznoi propahandы, 1923 - Vecher antyrelyhyoznoi propahandы v teatre «Kommuna» [An evening of anti-religious propaganda at the Kommuna theater] // Robitnyche-selianska pravda. 1923. 11 kvitnia. № 78. S. 3. Pidpys: D. [in Russian].

Vecher v klube, 1923 - Vecher v klube polyhrafystov [Evening at the club of printers] // Robitnyche-selianska pravda. 1923. 4 kvitnia. № 74. S. 2. Pidpys: D. [in Russian].

Vidhadai, 1923 - Bez boha khlib matymesh, a z bohom torbu chipliatymesh [Without God you will have bread, and with God you will cling to a bag] // Robitnyche-selianska pravda. 1923. 15 veresnia. № 209. S. 3. Pidpys: Selkor Vidhadai [in Ukrainian].

Vitrynska, 2016 - Vitrynska O. V. Polityka radianskoi vlady shchodo yudaizmu v Ukraini v 1921-1929 rokakh. [The policy of the Soviet government towards Judaism in Ukraine in 1921-1929] Dys... kand. ist. nauk. Poltava, 2016. 254 s. URL: https://shron1.chtyvo.org.ua/Vitrynska_Olena/Polityka radianskoi_vlady_schodo_iudaizmu_v_Ukraini_v 1921-1929 rokakh.pdf [in Ukrainian].

Volska, 1925 - Ne derzhit uchniv vdoma v relihiini sviata [Do not keep students at home on religious holidays] // Robitnyche-selianska pravda. 1925. 19 hrudnia. № 290. S. 3. Pidpys: Selkorka Volska [in Ukrainian].

Haievska, 2013 - Haievska T. Derzhavni radianski sviata: istoryko-kulturolohichnyi aspekt [State Soviet holidays: historical and cultural aspect] // Kulturolohichna dumka. 2013. № 6. S. 153-159. URL: http://nbuv.gov.ua/UJRN/ Kultdum_2013_6_21 [in Ukrainian].

Demennyi, 1923 - Shkola s. Kamianechoho boretsia z relihiinymy zabobonamy [School in the village of Kameneche struggles religious prejudices] // Robitnyche-selianska pravda. 1923. 14 kvitnia. № 81. S. 2. Pidpys: Demennyi [in Ukrainian].

Didus, 1923 - Antyrelihiina propahanda na paskhalni sviata v s. Hromakh [Anti-religious propaganda on Easter holidays in the village of Gromy] // Robitnyche-selianska pravda. 1923. 4 kvitnia. № 74. S. 2. Pidpys Didus [in Ukrainian].

Yev. Hen, 1924 - Shcho take sviato rizdva? [What is a Christmas holiday?] // Robitnyche-selianska pravda. 1924. 25 hrudnia. № 225. S. 2. Pidpys: Yev. Hen [in Ukrainian].

Zakrepym pobedu, 1923 - Zakrepym pobedu [Let's consolidate the victory] // Robitnyche-selianska pravda. 1923. 4 kvitnia. № 74. S. 1 [in Russian].

K antyrelyhyoznoi propahande, 1923 - K antyrelyhyoznoi propahande v paskhalnue dny [To anti-religious propaganda on Easter days] // Robitnyche-selianska pravda. 1923. 24 bereznia. № 65. S. 1 [in Russian].

K Komsomolskoi paskhe, 1923 - K Komsomolskoi paskhe [For Komsomolskaya Easter] // Robitnyche-selianska pravda. 1923. 29 bereznia. № 69. S. 3 [in Russian].

Kak obmantvaiut, 1923 - Kak obmantvaiut Yehovu [How Jehovah is Deceived] // Robitnyche-selianska pravda. 1923. 1 kvitnia. № 72. S. 2 [in Russian].

Kyrydon, 2017 - Kyrydon A. M. Indoktrynatsiia radianskosti: obriadovo-sviatkovyi kanon yak marker formuvannia ateizovanoho suspilstva (1920-1930-i rr.) [The indoctrination of Sovietness: a ceremonial-festive canon as a marker of the formation of an atheistic society (1920s-1930s)] // Umanska starovyna. 2017. Vypusk 3. S. 5-20. URL: http://www.irbis-nbuv.gov.ua/cgi-

bin/irbis_nbuv/cgiirbis_64.exe?I21DBN=LINK\&P21DBN=UJRN\&Z21ID=\&S21REF=10\&S21CNR=20\&S21STN=1 $\&$ S21FMT $=$ ASP_meta\&C21COM=S\&2_S21P03=FILA=\&2_S21STR=umanst_2017_3_3 [in Ukrainian].

Labenskyi, 1924 - S. Kniazhyky [The village of Knyazhiki] // Robitnyche-selianska pravda. 1924. 6 serpnia. № 107. S. 3. Pidpys: Labenskyi [in Ukrainian].

Litstudiia, 1925 - Litstudiia «Pluhu» pry Umanskim Ahrotekhnikumi [Litstudio "Plow" at Uman Agricultural College] // Robitnyche-selianska pravda. 1925. 15 kvitnia. № 85. S. 2. Pidpys: P. K. [in Ukrainian].

Makukha, 1923 - Borotba z relihiinymy zabobonamy v s. Pidvysokomu [Struggle against religious prejudices in the village of Pidvysoke] // Robitnyche-selianska pravda. 1923. 29 kvitnia. № 94. S. 2. Pidpys: Makukha [in Ukrainian].

Matukhno, 2017 - Matukhno Yu. O. Problema klasyfikatsii radianskykh sviat u pershe porevoliutsiine desiatylittia [The problem of classifying Soviet holidays in the first post-revolutionary decade] // Naukovi pratsi istorychnoho fakultetu Zaporizkoho natsionalnoho universytetu. 2017. Vyp. 48. S. 139-142. URL: http://www.irbis-nbuv.gov.ua/cgibin/irbis nbuv/cgiirbis_64.exe?C21COM=2\&I21DBN=UJRN\&P21DBN=UJRN\&IMAGE_FILE_DOWNLOAD=1\&I mage file name=PDF/Npifznu $2017 \_48$ 27.pdf 
Medsanrabotnyky, 1923 - Medrabotnyky ne otstaiut [Medical workers are not lagging behind] // Robitnyche-selianska pravda. 1923. 6 kvitnia. № 76. S. 2 [in Russian].

Na obshchem sobranyy, 1923 - Na obshchem sobranyy transportnykov y stroytelei [At a general meeting of transport workers and builders] // Robitnyche-selianska pravda. 1923. 31 bereznia. № 71. S. 3 [in Ukrainian].

Naiblyzhchi zavdannia, 1924 - Naiblyzhchi zavdannia raionnykh komisii po protyrelihiinii propahandi [Immediate tasks of district commissions for anti-religious propaganda] // Robitnyche-selianska pravda. 1924. 11 sichnia. № 7. S. 3 [in Ukrainian].

Novoselytskyi, 1923 - Novoselytskyi F. Stradaiushchye y voskresaiushchye bohy y yskuplenye ymy liudskykh hrekhov [Suffering and resurrecting gods and their atonement for human sins] // Robitnyche-selianska pravda. 1923. 20 bereznia. № 61. S. 2 [in Russian].

Paskhalnaia kampanyia, 1923 - Paskhalnaia kampanyia [Easter campaign] // Robitnyche-selianska pravda. 1923. 28 bereznia. № 68. S. 3 [in Russian].

Polytprosvet, 1923 - Prazdnyk Paskhy у paskhalnые obriadы [Easter holiday and Easter ceremonies] // Robitnycheselianska pravda. 1923. 20 bereznia. № 61. S. 2. Pidpys: Polytprosvet Ukoma KSM [in Russian].

Polishchuk, 2009 - Polishchuk V. Onoprii Turhan - zhurnalist i pysmennyk [Onopriy Turgan is a journalist and writer] URL: https://umanliteratura.ucoz.ua/news/v_polishhuk_onoprij_turgan_zhurnalist_i_pismennik/2010-12-20-256 [in Ukrainian].

Popova, 1925 - Popova O. Sviatkuimo ne bozhi sviata, a sviata pratsi y peremohy [Let us celebrate not God's holidays, but the holidays of work and victory] // Robitnyche-selianska pravda. 1925. 12 kvitnia. № 83. S. 2 [in Ukrainian].

Proletshkola, 1923 - Proletshkola protyv boha [Proletarian school against god] // Robitnyche-selianska pravda. 1923. 28 bereznia. № 68. S. 2 [in Russian].

Rabkor, 1923 - Budem borotsia s relyhyei kak y s vooruzhennыm vrahom [We will fight religion like an armed enemy] // Robitnyche-selianska pravda. 1923. 3 kvitnia. № 73. S. 3. Pidpys: Rabkor K. [in Ukrainian].

Rabota ahytpropa, 1923 - Rabota ahytpropa v aprele [Agitprop work in April] // Robitnyche-selianska pravda. 1923. 9 travnia. № 101. S. 3 [in Russian].

Robitnyk, 1924 - Osvitu zhintsi na seli [Education for a woman in the countryside] // Robitnyche-selianska pravda. 1924. 8 liutoho. № 18. S. 3. Pidpys: Robitnyk [in Ukrainian].

Robitnyche zhyttia, 1924 - Robitnyche zhyttia [Working life] // Robitnyche-selianska pravda. 1924. 23 kvitnia. № 48. S. 3 [in Ukrainian].

Sylantiev, 2005 - Sylantiev V. I. Vlada i pravoslavna tserkva v Ukraini (1917-1930 rr.) [Authorities and the Orthodox Church in Ukraine (1917-1930)] Avtoref. dys... dokt. ist. nauk. Kharkiv, 2005. 46 s. [in Ukrainian].

Syrotiuk, 1924 - Zubrytskyi KNS ne porvav shche z relihiieiu [The Zubrytsia CPP has not yet broken with religion] // Robitnyche-selianska pravda. 1924. 5 sichnia. № 4. S. 2. Pidpys: Syrotiuk [in Ukrainian].

Sidorenko, 1923 - Sidorenko Z. Neobkhidna chystka komnezamu s. Pobiinoi [It is necessary to clean the komnezam of the village of Pobiyna] // Robitnyche-selianska pravda. 1923. 19 kvitnia. № 85. S. 2 [in Ukrainian].

Soloviov, 1924 - Soloviov D. Nebazhane yavyshche [An undesirable phenomenon] // Robitnyche-selianska pravda. 1924. 16 sichnia. № 9. S. 2 [in Ukrainian].

Tabel, 1924 - Tabel sviat i nerobochykh dniv. Oboviazkova postanova Kyivskoho hubvykonkomu № 49 vid 19 bereznia 1924 roku [Table of holidays and non-working days. Mandatory Resolution of the Kyiv Provincial Executive Committee № 49 of March 19, 1924] // Vistnyk Kyivskoho hubvykonkomu. 1924. 2 kvitnia. № 14. S. 2 [in Ukrainian].

Tarapon, 2016 - Tarapon O. Derzhavni sviata v Ukraini 1920-1930-kh rr. yak zasib formuvannia radianskykh politychnykh tsinnostei [Public holidays in Ukraine in the 1920s and 1930s as a means of forming Soviet political values] // Aktualni pytannia humanitarnykh nauk: mizhvuzivskyi zbirnyk naukovykh prats molodykh vchenykh Drohobytskoho derzhavnoho pedahohichnoho universytetu imeni Ivana Franka. Drohobych, 2016. Vyp. 15. S. 96-102. URL: http://nbuv.gov.ua/UJRN/apgnd_2016_15_13 [in Ukrainian].

Tolko 40 pyshchevykov, 1923 - Tolko 40 pyshchevykov ne odurachenы relyhyei [Only 40 food workers are not fooled by religion] // Robitnyche-selianska pravda. 1923. 31 bereznia. № 71. S. 3 [in Russian].

Turhan, 1924 - Turhan O. Proty staroho rizdva [Against old Christmas] // Robitnyche-selianska pravda. 1924. 24 hrudnia. № 224. S. 2 [in Ukrainian].

Fiialko, 1923 - Fiialko S. Antyrelihiina propahanda v s. Ksendzivtsi [Anti-religious propaganda in the village of Ksendzivka] // Robitnyche-selianska pravda. 1923. 19 kvitnia. № 85. S. 2 [in Ukrainian].

Flerovskyi, 1923 - Flerovskyi Y. Stradaiushchyi, umershyi y voskresshyi... [Suffering, dead and resurrected...] // Robitnyche-selianska pravda. 1923. 6 kvitnia. № 76. S. 3 [in Russian].

Flierovskyi, 1925 - Flierovskyi I. Zvidky pishly tserkovni sviata [Where did the church holidays come from?] // Robitnyche-selianska pravda. 1925. 10 kvitnia. № 81. S. 2 [in Ukrainian].

Tserkvy, 1923 - Tserkvy, kostelы, synahohy - pod klubы y teatrы [Churches, churches, synagogues - for clubs and theaters] // Robitnyche-selianska pravda. 1923. 6 kvitnia. № 76. S. 2 [in Russian].

Chuchalin, 2019 - Chuchalin O. P. Vplyv ateistychnoi propahandy radianskoi presy na relihiinu sytuatsiiu v USRR u 1920-1930-ti rr. [The influence of atheistic propaganda of the Soviet press on the religious situation in the USSR in the 1920s and 1930s] // Hileia: naukovyi visnyk. 2019. Vypusk 142(1). S. 182-188. URL: http://www.irbisnbuv.gov.ua/cgi- 
bin/irbis_nbuv/cgiirbis_64.exe?I21DBN=LINK\&P21DBN=UJRN\&Z21ID=\&S21REF=10\&S21CNR=20\&S21STN=1 \&S21FMT =ASP_meta\&C21COM=S\&2_S21P03=FILA=\&2_S21STR=gileya_2019_142(1)_39 [in Ukrainian]. Yunenko, 1925 - Yunenko S. Nash KNS [Our CPP] // Robitnyche-selianska pravda. 1925. 16 sichnia. № 9. S. 3 [in Ukrainian].

УДК 94:81’373.21](477.65-21 Зінов’ євськ) «1924»

\author{
Олександр ЧОРНИЙ \\ orcid.org/0000-0001-5169-3554 \\ кандидат історичних наук, \\ доцент кафедри історії України, \\ Центральноукраӥнський державний педагогічний \\ університет імені Володимира Винниченка \\ (Україна, Кропивницький) \\ komandarmus12@gmail.com
}

\title{
1924 : ЄЛИСАВЕТГРАД - ЗІНОВ'СВСЬК. ХРОНІКА ПЕРЕЙМЕНУВАННЯ
}

Радянізація топонімї̈ в СРСР, щ⿻о прокотилася в 1920-х - 1930-х роках, значно вплинула на формування в межах усієі краӥни тисяч нових географічних назв, якими увічнювалися вожді РКП(б) - ВКП(б). Широкомасштабне перейменування у 1920-х - 1930-х роках охопило і радянську Украйну. Укорінену радянську топонімію в УСРР-УРСР вдалося частково ліквідувати лише у 2015-2016 роках під час декомунізації в Украӥні. Серед великих міст на територї радянськоӥ України одним із перших було перейменовано Слисаветград. 7 серпня 1924 року воно отримало назву Зінов'євськ, на честь діяча більщовицької партіі Г. О. Зінов'єва.

У дослідженні вперше на основі архівних документів та матеріалів місиевої газети «Червоний илях» названо ініціаторів перейменування, а також відтворено подробиці «вибору» нового «революиіииного» імені для «пролетарського» міста. Автор довів, щчо поштовхом до зміни назви Слисаветграда стала смерть В. I. Леніна та перейменування на його честь Петрограда в Ленінград, щуо ініціатива щуодо перейменування Слисаветграда належала місцевим партійним функиіонерам, щзо нова назва Зінов'євськ була узгоджена 3 самим Г. О. Зінов'євим задовго до офіиійного перейменування міста постановою ЦВК СРСР, щзо він радо вітав увічнення свого імені та високо оцінював факт набуття містом нової назви, шчо перейменування 1924 року $з$ часом спровокувало повторні перейменування у 1934 та 1939 роках.

Аналіз процедури перейменування та методів переконування містян, щзо нова назва дасть можливість усім «жити по-новому», дозволяє зрозуміти болісність декомунізації та небажання ї̈ реалізації у 1990-х - y середині 2010-х років.

Ключові слова: партія, більшовики, місто, перейменування, Єлисаветград, Зінов'євськ, П. П. Амосов, Г. О. Зінов'єв.

\author{
Oleksandr CHORNYI, \\ Candidate of Sciences in History \\ Associate Professor \\ of the Department of the History of Ukraine \\ Volodymyr Vynnychenko \\ Central Ukrainian State Pedagogical University \\ (Ukraine, Kropivnitsky) \\ komandarmus12@gmail.com
}

\section{4: YELYSAVETGRAD - ZINOVYEVSK. CHRONICLE OF RENAMING}

The Sovietization of toponymy in the USSR, which took place in the 1920-s and 1930-s, significantly influenced the formation of new names of cities, villages, towns, squares, streets and other geographical objects. The result was the emergence of thousands of new geographical names throughout the country, which perpetuated the leaders of the $R C P(b)-V K P(b)$. The large-scale renaming in the 1920-s and 1930-s also covered Soviet Ukraine. The introduction of Soviet toponymy in the USSR became a significant domestic problem after Ukraine gained independence. The Soviet legacy in toponymy partially eliminated only in 2015-2016 during decommunization in Ukraine.

Among the large cities in Soviet Ukraine, Yelysavethrad was one of the first to rename. On August 7, 1924 the city named Zinovievsk in honor of the Bolshevik Party activist Grigoriy Ovsievich Zinoviev (Ovsiy-Gershen Aronovich 
Radomyslsky). This was the second time in the history of the USSR that a geographical object named after a still-living leader.

To understand the logic and actions of the party leadership on Soviet toponymy in the USSR and the union republics, the author in the proposed study reconstructed in detail the events surrounding the preparation and renaming of Yelysavethrad to Zinovievsk. The author first named the initiators of the renaming, and introduced the details of "choice» of a new "revolutionary» name for the "proletarian» city. The research based on archival documents and materials of the newspaper "Red Way», which in the 1920-s was the main media in the city.

The author proved that the impetus for changing the name of Yelysavethrad was the death of V. Lenin and the renaming of Petrograd in his honor in Leningrad. The initiative to rename Yelysavethrad belonged to local party functionaries. The new name Zinovievsk was agreed with G. Zinoviev before the official renaming of the city, a resolution of the CEC of the USSR that Comrade Zinoviev welcomed the perpetuation of his name and praised the fact that the city acquired a new name, that the renaming in 1924 eventually provoked renaming in 1934 and 1939. The researcher cited a number of extensive quotations from relevant documents and materials that help to present the general atmosphere and party rhetoric around the issue of renaming the city.

An analysis of the renaming procedure and methods of convincing citizens that the new name will allow everyone to live in a new way allows us to understand the problems of decommunization and the reluctance to implement it in the 1990-s-mid-2010-s.

Key words: party, Bolsheviks, city, renaming, Yelysavethrad, Zinovievsk, P. Amosov, G. Zinoviev.

\section{Постановка проблеми. 3 утворенням СРСР партія більшовиків} запустила механізм впливу на культурні процеси в країні, результатом яких мала стати тотальна віра радянських людей в краще майбутнє до якого їх поведе правляча партія та іiі вожді. Вождізм серед прихильників РКП(б)ВКП(б) почав формуватися ще під час боротьби за встановлення радянської влади на території колишньої Російської імперії. Формування віри в провідників партії та використання іiі, як засобу впливу на пересічних громадян 3 метою перетворення їх на радянських людей, стало своєрідним трансформованим варіантом моделі віри в «доброго і справедливого царя». На початку 1920 -х років більшовики почали активно використовувати образи своїх лідерів для пропагування переваг радянської влади та ідеї панування світового пролетаріату. Якщо до утворення СРСР у прихильників більшовицької ідеології влада асоціювалася з багатьма лідерами РКП(б)-ВКП(б), то вже з 1922 року на недоторканого авторитета для них почав перетворюватися В. І. Ленін. Довкола його постаті почав формуватися культ, появі якого сприяв сам Ілліч (Шалаева, 2013: 104). Більшовикам культ Леніна потрібен був для повної легітимації їхньої влади на всіх підконтрольних територіях та поміж усіма верствами населення. Правляча партія у такий спосіб намагалася встановити тісний емоційний зв'язок і зі своїми симпатиками, і з тими, хто зі сторони споглядав за політичними процесами в країні. Смерть В. І. Леніна у січні 1924 року неабияк посприяла формуванню подальшого культу довкола його постаті і справ. Кончина більшовицького вождя стала поштовхом до широкомасштабної радянізації топонімії в межах усього СРСР. Як показав час, це стало дієвим кроком і в справі легітимації більшовицької партії по всьому СРСР, і для пропаганди радянської влади, як влади робітників і селян. Наслідки радянізації топонімії в межах радянської України не вдалося повністю подолати, навіть, через 30 років після розпаду СРСР та проведеної в Україні у 2015-2016 роках декомунізації. Для прикладу, в Україні Кіровоградська область й досі іменується на честь діяча більшовицької партії С. М. Кірова, а в назві Дніпропетровської області увічнений Г. І. Петровський - ще один одіозний функціонер ВКП(б)-КП(б)У. 
Досить потужним радянським маркером в УРСР та Україні було місто Кіровоград (з 2016 року - Кропивницький), яке в радянський час офіційно перейменовувалося тричі. У 1924 році історична назва міста - Слисаветград була замінена на Зінов'євськ, 1934 року - на Кірово, а 1939 року - на Кіровоград. Знаковим для розуміння проблеми радянізації топонімії в УСРР в 1920-х роках є приклад перейменування міста Єлисаветграда в Зінов'євськ у 1924 році, якому присвячена пропонована публікація.

Аналіз досліджень щодо окресленої проблеми засвідчує, що вона не була предметом окремої наукової розвідки, оскільки Г. О. Зінов’єв, на честь якого було перейменовано місто, був репресований та розстріляний. Нічого з цього приводу не повідомляє і академічне видання «Історія і міст сіл УРСР. Кіровоградська область» (Історія, 1972: 81-124). Автори нарису про Кіровоград (П. М. Безтака та О.Ф. Нагорний), керуючись методичними порадами редколегії видання, торкаючись історії міста 1920-х - 1930-х років, подали матеріали так, що місто «за клопотанням трудящих» у 1934 році було перейменовано в Кірово (Історія, 1972: 106), а до того ніби то мало назву Єлисаветград.

Не користувалася популярністю окреслена проблема і в середовищі кіровоградських-кропивницьких краєзнавців. Серед останніх увага проблемі перейменування міста у 1924 році й досі приділяється лише як до факту зміни назви міста. Сдина краєзнавча розвідка С. І. Шевченка, яка містить деякі подробиці зміни назви міста у 1924 році, була опублікована в газеті «Молодий комунар» 1988 року (Шевченко, 1988). Автор порушив проблему на фоні реабілітації Г. О. Зінов'єва у липні 1988 року.

Виходячи із зазначеного вище, глибоке, аналітичне дослідження проблеми перейменування Єлисаветграда в Зінов'євськ $є$ актуальним, оскільки дозволяє глибше зрозуміти природу та мету радянізації топонімії в УСРРУРСР, а також відновити малодосліджений епізод з історії міста.

Мета статті полягає в детальній реконструкції подій, пов'язаних 3 перейменування Єлисаветграда в Зінов’ євськ у 1924 році. Реалізація мети стала можливою шляхом комплексного вивчення проблеми в контексті синхронних подій республіканського та союзного значення.

Джерельною базою для підготовки дослідження стали документи з історії окресленої проблеми, що зберігаються в Державному архіві Кіровоградської області та матеріали, що були опубліковані у 1924 році в газеті «Червоний шлях», яка була не лише друкованим «органом Слисаветградського окркому, окрвиконкому КП(б)У й окрпрофбюро», а й головним періодичним виданням міста. Практично всі використанні матеріали введені до наукового обігу вперше.

Виклад основного матеріалу. Смерть В. І. Леніна 21 січня 1921 року відразу ж викликала серед соратників вождя ідею помпезного увічнення його імені. Але більшовики переслідували ще одну мету - ідеологічного впливу на громадян, як засобу формування в найближчому майбутньому монолітного суспільства «радянських людей», готових боротися за перемогу світової пролетарської революції. У цьому контексті знаковою є промова М. І. Калініна, 
виголошена на II з’їзді рад СРСР 26 січня 1924 року, в якій він обгрунтував ідею перейменування Петрограда в Ленінград тим, що «Червоний Петроград $\epsilon$ колискою пролетарської революції», що місто $\epsilon$ «першою цитаделлю радянської влади», що воно має носити ім'я ії творця (Второй, 1924: 54-55). Промова М. І. Калініна та пропозиція Петроградської ради робітничих, солдатських і селянських депутатів була одностайно підтримана делегатами i 26 січня 1924 року (за день до поховання В. І. Леніна) Петроград було перейменовано в Ленінград. Після цього в багатьох містах РРФСР та союзних республік наприкінці січня - на початку лютого 1924 року масово відбулися збори партійних активів на фабриках і заводах, учасники яких тотально «вимагали найскорішого перейменування» ряду міст на честь Леніна. ЦВК СРСР фактично був завалений такими «пропозиціями-вимогами». Практично в усіх зверненнях пропозиції нових назв були однаковими або однотипними - Ленінськ, Ленінське, Ілліч, Ульянов, Ульяновськ. І лише деякі 3 них вирізнялися оригінальністю, на зразок - Ленінодар або Ленінбург (Вержбиньски, 2012: 105).

Не стали осторонь топонімічної ленінізації і «пролетарі» з Слисаветграда. За ініціативи директора заводу «Червона Зірка» П. А. Заривайка робітники підприємства поставили питання про перейменування міста, обравши для нього нову назву - Ленінськ (К переименованию, 1924b: 2). Але реалізація цієї ідеї не набула актуальності, оскільки ЦВК СРСР, зіштовхнувшись з сотнями подібних побажань, змушений був відмовитися від огульної практики перейменувань на честь В. І. Леніна. Уже 5 лютого 1924 року в СРСР було прийнято постанову «Про перейменування міст, вулиць, закладів і т.д. у зв'язку зі смертю В. I. Ульянова-Леніна», якою без попереднього узгодження 3 Президією ЦВК СРСР перейменування на честь вождя категорично заборонялося (Дамбуев, 2015: 291), аби масово не наплодити в СРСР географічних ленінізмів. Це могло створити великі проблеми для транспорту, пошти та засобів зв'язку у межах усієї країни. 1924 року імені вождя були удостоєні лише міста Ульяновськ (до того Симбірськ) та Ленінакан (до того Олександрополь). Але попит на «революційні» назви більшовики все ж почали задовольняти, маркуючи простори СРСР радянськими топонімами, увічнюючи інших більшовицьких лідерів та різномастих борців за світле майбутнє. Фактично в середині - у другій половині 1920 -х років в країні була започаткована політика радянізації топонімії.

Повторно до ідеї перейменування міста в Єлисаветграді повернулися в березні-квітні 1924 року. Серйозно цим питанням зайнявся Слисаветградський окружний комітет КП(б)У та іiі окружний виконавчий комітет. Відповідно очолювані у 1924 році Петром Пилиповичем Амосовим та Григорієм Павловичем Радченком.

Саме П. П. Амосов (перша особа в окружному комітеті КП(б)У) розгорнув широку роботу, щодо перейменування Слисаветграда та повторно обгрунтував необхідність цього. Основним мотивом для зміни назви міста П. П. Амосов вбачав у тому, що воно «іменується ганебною та нереволюційною назвою» (ДАКО. Ф. П-2. Оп. 1. Спр. 94. Арк. 36). За результатом обговорення 
можливого перейменування Єлисаветграда у березні-квітні 1924 року в партійних колах окружного комітету, окружного виконавчого комітету, окружного комітету профспілки та в колективі заводу «Червона Зірка» було визначено ряд можливих i, саме головне, «революційних» назв для міста. Найбільш популярними стали Зінов'євськ, Троцьк, Левград, Ілліч.

3 метою втілення в життя ідеї перейменування міста була створена спеціальна комісія, до якої увійшли П. П. Амосов, Г. П. Радченко, А. В. Дейниченко (голова окружного профспілкового бюро), М. Г. Когут (голова окружного комітету незаможних селян), П. О. Бржезінський (завідувач відділом комунального господарства окрвиконкому), М. О. Сеничкін (окружний військовий комісар), 3. К. Гуревич (секретар окружного комітету комуністичного союзу молоді), І. Л. Ронес (завідувач відділом агітації та пропаганди окружного комітету партії), М. М. Кортунов (завідувач окружного земельного управління), Д. А. Агронов (секретар окрвиконкому) та П. М. Парфьонов (завідувач інформаційним відділом окружного комітету партіі). Головою комісії 3 перейменування був обраний заступник голови окрвиконкому М. К. Іванов (ДАКО. Ф. Р-250. Оп. 3. Спр. 15. Арк. 13-14.).

Комісія вирішила винести питання про перейменування міста на обговорення під час роботи 8-ї окружної партійної конференції, яка мала відбутися 23-26 квітня 1924 року.

23 квітня (в день відкриття конференції) Єлисаветградський окрвиконком розіслав усім головам райвиконкомів обіжник (лист) № 6475 за підписом голови окрвиконкому Г. П. Радченка та секретаря Д. А. Агронова, у якому було поставлено завдання визначитися 3 вибором нової назви для Єлисаветграда (ДАКО. Ф.250. Оп. 3. Спр. 15. Арк. 1 a). Головам райвиконкомів пропонувалося обговорити на розширених засіданнях райвиконкомів, районних комітетів незаможних селян разом із представниками сільрад можливість перейменування Єлисаветграда в Зінов'євськ (на честь Г. О. Зінов'єва) або в Левград (на честь Л. Д. Троцького).

23-24 квітня 1924 року в Єлисаветграді в приміщенні Першого радянського театру працювала 8-а окружна партійна конференція (Открытие, 1924: 2), делегати якої обговорили стан сільського господарства і промисловості в окрузі, питання партійного будівництва в Єлисаветграді та селах округи, оцінили роботу комуністичного союзу молоді та оновили склад окружного комітету КП(б)У (ДАКО. Ф. П-2. ОП. 1. Спр. 94. Арк. 6-34). Питання перейменування міста в основний порядок денний роботи конференції не було включене (Амосов, 1924: 1). Воно розглядалося 24 квітня і було запропоноване для розгляду 3 голосу, коли мали обговорюватися дрібні проблеми в “різному” (ДАКО. Ф. П-2. Оп. 1. Спр. 94. Арк. 15-35).

Щодо перейменування міста виступив голова окружного комітету КП(б)У Петро Пилипович Амосов. Він зазначив, що перейменування Єлисаветграда вже давно заплановане радянськими органами, що місто має отримати “революційну” назву, що трудящі міста “принципово висловилися” за його перейменування. Також доповідач констатував, що в місті серед робітників стосовно нової назви сформувалося дві пропозиції - перейменувати 
Єлисаветград в Зінов'євськ або ж дати місту нову назву Левград. При цьому доповідач наголосив, що назву Зінов'євськ підтримує більшість трудящих, оскільки «товариш Зінов'єв» народився в Слисаветграді, а назва Троцьк не така популярна i не користується підтримкою більшості, оскільки «товариш Троцький» народився у Бобринці. Підсумовуючи сказане, П. П. Амосов наголосив, що «ми висловлюємося за першу пропозицію, за Зінов' євськ» (ДАКО. Ф. П-2. Оп. 1. Спр. 94. Арк. 36)

На противагу П. П. Амосову виступили директор заводу «Червона Зірка» П. А. Заривайко та заступник голови Слисаветградського окрвиконкому М. К. Іванов (той, що очолював комісію з перейменування міста), які дозволили собі не погодитися 3 позицією основного доповідача. П. А. Заривайко запропонував перейменувати Слисаветград в Ілліч. У цьому плані його позиція щодо найменування міста на честь В. І. Леніна залишилася незмінною, оскільки саме він першим серед партійних функціонерів міста та округи висловив ідею замінити назву Слисаветграда на «революційну».

М. К. Іванов теж не погодився з П. П. Амосовим і виступив 3 пропозицією дати місту назву Троцьк. Обидва варіанти - і Левград, і Троцьк передбачали увічнення Л. Д. Троцького, але назва Троцьк виглядала більш «революційно».

Факт виступів П. А. Заривайка та М. К. Іванова ставить під сумнів твердження П. П. Амосова про те, що назву Зінов'євськ підтримувала більшість трудящих. До того ж, П. А. Заривайко висловив не лише свою позицію, а й думку робітників заводу «Червона Зірка», який у 1920-х роках значною мірою був містоутворюючим підприємством у Єлисаветграді. Та й популярність В. І. Леніна і Л. Д. Троцького у 1924 році серед членів ВКП(б)-КП(б)У та тих, хто їм симпатизував, була значно більшою, ніж постать Г. О. Зінов'єва. Не дивлячись на це, делегати ухвалили перейменувати місто в Зінов'євськ (ДАКО. Ф. П-2. Оп. 1. Спр. 94. Арк. 36), «йдучи на зустріч побажанням робітників i селян округи». Принагідно варто наголосити, що думка селян щодо цього ще була невідомою, оскільки реакції на згадуваний лист за № 6475 Єлисаветградського окрвиконкому з райвиконкомів округи ще не надходило.

Виходячи 3 цього, можемо припустити, що бажання перейменувати місто в Зінов'євськ - це бажання очільника окркому П. П. Амосова та його найближчого оточення. Наше припущення грунтується на тому, що П. А. Заривайко виступив на конференції не для красного слівця i не на замовлення. Справа в тім, що він був, як тоді писали, «палким ленінцем» і до того, як перейшов на партійну i господарську роботу встиг послужити комісаром в армії, навіть, брав участь в обороні Царицина (Заривайко, 1987: 209). До того ж Г. О. Зінов'єв, як уродженець міста, його мешканцям був невідомий. Це доводить той факт, що газета «Червоний шлях» після конференції кілька разів зверталася до жителів Єлисаветграда надати в редакцію матеріали про Г. О. Зінов'єва, про його життя та роботу в місті, спогади про нього, аби розмістити в спецвипуску газети, який мав побачити світ «в день перейменування Слисаветграда в Зінов'євськ» (От редакции, 1924а: 1; От редакции, 1924b: 1; От редакции, 1924c: 1; От редакции, 1924d: 1).

Опираючись на ухвалу 8-ї окружної партійної конференції щодо 
перейменування міста, П. П. Амосов отримав карт-бланш стосовно зміни назви Слисаветграда у найближчому майбутньому.

У цій частині пропонованого дослідження варто сказати кілька слів і про самого ідеолога перейменування Єлисаветграда в Зінов’ євськ - «товариша Амосова». У середовищі краєзнавців міста його й досі вважають робітником заводу «Червона Зірка», який «полум'яно» і вдало закликав перейменувати місто під час роботи окружної партійної конференції. Мало того, окремі «знавці» теми по старій радянській традицій й досі називають його «делегат Амосов» (Матівос, 2004: 60-61), ніби в нього не було ні імені, ні по батькові. Тим часом партійна картка на товариша Амосова Петра Пилиповича свідчить, що він був уродженцем Смоленщини, що народився 1897 року, що очолив Єлисаветградський окружний комітет КП(б)У в жовтні 1923 року, що до того брав участь у подіях Лютневої революції та Жовтневого перевороту в Петрограді у 1917 році (ДАКО. Ф. 250. Оп. 1. Спр. 433. Арк. 5), попрацював на партійній роботі в Пензенській та Одеській губерніях, в Петрограді, Одесі, Балті та Миколаєві (ДАКО. Ф. 250. Оп. 1. Спрю 83. Арк. 23). Працюючи на різних партійних посадах, брав участь у викачуванні хліба на півдні України та чистці радянського апарату у складі робітничо-селянських інспекцій. Будучи уповноваженим особливої комісії по продовольству в Балтському повіті Одеської губернії, став причетним до організації голоду на півдні України. Власноручно заповнені анкети теж дозволяють додати характеристики «товаришу Амосову». Для прикладу, в графі «національність» він указав «великорос», а щодо освіти зазначив - «образование нисшее» (ДАКО. Ф. 250. Оп. 1. Спр. 83. Арк. 22-23). Як бачимо, це був доволі тертий калач в партійній організації міста та округи.

Проаналізувавши ситуацію, що склалася на конференції під час обговорення питання про перейменування, П. П. Амосов почав діяти. 28 квітня 1924 року було скликано пленум Слисаветградської міської ради робітничих, солдатських та селянських депутатів, на якому було прийнято постанову про перейменування Єлисаветграда в Зінов'євськ. 3 травня на засіданні Єлисаветградського окрвиконкому було ухвалено аналогічне рішення. 5 травня таку ж постанову було прийнято на пленумі 5-го окружного з'їзду профспілок Єлисаветградщини (ДАКО. Ф. 250. Оп. 3. Спр. 15. Арк. 10а-11).

5 травня Слисаветградський окрвиконком направив листа за № 5376 до Одеського губвиконкому, яким ознайомив губернське партійне керівництво із ситуацією, що склалася довкола перейменування міста та висловив клопотання перейменувати Слисаветград в Зінов’ євськ (ДАКО. Ф. 250. Оп. 3. Спр.15. Арк. 8).

37 травня на адресу комісії з перейменування міста почали надходити рішення щодо вибору нової назви міста з районів. 313 районів, що входили до складу Єлисаветградської округи в 1924 році, ухвали надійшли лише 35 (Новоукраїнського, Компаніївського, Новомиргородського, Великовисківського та Злинського), також свої рішення надіслали Глодоська та Розсоховатська сільські ради (ДАКО. Ф. 250. Оп. 3. Спр. 15. Арк. 2, 4, 6, 16, 18, 20, 21). Усі названі райвиконкоми та сільські ради підтримали назву Зінов'євськ. 
Для дискредитації назви Єлисаветград завідувачу відділу агітації та пропаганди (агітпропу) Єлисаветградського окружного комітету КП(б)У І. Л. Ронесу було доручено розробити відповідні матеріали для широкого використання під час партійних та профспілкових зборів, для читання публічних лекцій на підприємствах та публікації в пресі.

Паралельно 3 цими подіями, П. П. Амосов та М. К. Іванов зустрілися в Харкові 3 Головою Всеукраїнського ЦВК Г. І. Петровським i Народним комісаром юстиції УСРР М. О. Скрипником та узгодили перейменування 3 ними. На переговорах Г. І. Петровський підтримав та схвалив ідею і бажання П. П. Амосова (К переименованию, 1924b: 2).

23-31 травня 1924 року у Москві відбувся XIII з’їзд ВКП(б), делегатом якого від Єлисаветградської округи був П. П. Амосов. Під час роботи з'їзду він особисто зустрівся з Г. О. Зінов'євим та ознайомив його з тим, що робітники i селяни Слисаветградщини «категорично вирішили назвати округу і місто на його честь» (К переименованию, 1924b: 2). За словами того ж П. П. Амосова «товариш Зінов' єв посміхнувся і сказав, що він згоден».

Заручившись підтримкою Г. І. Петровського, М. О. Скрипника і самого Г. О. Зінов'єва, очільник Єлисаветградського окружного комітету партії почав діяти ще активніше. У червні 1924 року газета «Червоний шлях» почала друкувати підготовлені окружним агітпропом, дискредитуючі стару назву, матеріали, зміст яких зводився до того, що місто більше не може носити «ганебну і нереволюційну» назву, що робітники і селяни більше не можуть «терпіти і не хочуть чути на кожному кроці найгіршу назву з усіх найгірших», яка увічнює розпусну царицю Єлисавету, яку після смерті «причислили до лику святих», що перейменування - це спосіб «вичистити огидне минуле» 3 повсякденного вжитку «трудового народу», який впевнено розбудовує своє майбутнє, що назва Зінов'євськ - це честь для міста, оскільки «товариш Зінов’єв - провідник Ленінізму» (Агітпроп, 1924: 2; К переименованию, 1924а: 3). Як бачимо, ці словесні маніпуляції були розраховані на тих, хто вже чітко став на шлях руйнування «старого світу до кінця аби потім на його руїнах збудувати новий».

11 червня 1924 року на засіданні комісії по перейменуванню міста та округи з Слисаветграда в Зінов'євськ було прийнято рішення приурочити перейменування відкриттю 5-го Конгресу Комінтерну та просити ВУЦВК надіслати телеграфом на адресу комісії постанову про перейменування Єлисаветграда в Зінов' євськ до відкриття Конгресу, який, як відомо, працював у 1924 році у Москві з 17 червня по 8 липня (Коммунистический, 1969: 220). Також комісія ухвалила в день перейменування міста випустити спецвипуск газети «Червоний шлях», присвячений «товаришу Зінов’єву», до дня перейменування окружному комітету спеціальною директивою зобов'язати всіх очільників райвиконкомів, промислових підприємств та кооперативних організацій в обов'язковому порядку виготовити нові вивіски, печатки та штампи. Окрім того, очільникам райвиконкомів довести до відома, що в усіх “заштатних містах і містечках" під час розпланування вулиць «виділити одну» для найменування на честь «товариша Зінов'єва». Також було визначено 
провести святкування перейменування не лише в місті, а й по всій окрузі, в тому числі і по селах (ДАКО. Ф. 250. Оп. 3. Спр. 15. Арк. 14).

Того ж дня М.К. Іванов відправив телеграму до ВУЦВК 3 проханням дозволити перейменувати Слисаветград в Зінов'євськ, оскільки перейменування приурочено відкриттю 5-го Конгресу Комінтерну (ДАКО. Ф. 250. Оп. 3. Спр. 15. Арк. 15). Через кілька днів все той же «товариш Іванов» повторно звернувся до Г. І. Петровського 3 проханням «прискоритися 3 відповіддю» щодо перейменування міста до дня відкриття Конгресу (ДАКО. Ф. 250. Оп. 3. Спр. 15. Арк. 22), а також повторно 24 червня звернувся до Одеського губвиконкому $з$ проханням посприяти у вирішенні того ж питання (ДАКО. Ф. 250. Оп. 3. Спр. 15. Арк. 26). Активності П. П. Амосову та членам комітету з перейменування міста додавав ще й той факт, що 6 червня 1924 року в УСРР м. Юзівка було перейменоване в м. Сталін (Постановление, 1924b: 199).

Не дивлячись на таку активність ініціаторів надання місту «революційної» назви, ВУЦВК лише 4 липня о 13:55 надіслав телеграму до окрвиконкому, в якій зазначалося, що «питання по перейменуванню Єлисаветграда в Зінов'євськ буде вирішено найближчим часом» (ДАКО. Ф. 250. Оп. 3. Спр. 15. Арк. 24). 3 огляду на це, окружний комітет КП(б)У відправив до Харкова М. М. Кортунова, очевидно для того, щоб він «прискорив» підготовку постанови про перейменування, оскільки саме він 7 липня 1924 року о 19:40 телеграфом передав для окружного комітету повідомлення, що «особиста згода Петровського $\epsilon$, завтра буде постанова Президії» (ДАКО. Ф. 250. Оп. 3. Спр. 15. Арк. 25).

8 липня 1924 року на засіданні Малої Президії ВУЦВК було затверджено постанову Центральної адміністративно-територіальної комісії про перейменування м. Слисаветграда в м. Зінов'євськ 3 одночасним перейменуванням Слисаветградської округи в Зінов’ євську. Також ВУЦВК порушив питання перед ЦВК СРСР про перейменування станції Слисаветград у станцію Зінов’ євськ (ДАКО. Ф. 250. Оп. 3. Спр. 15. Арк. 27а). Не дивлячись на те, що Постанова ВУЦВК «Про перейменування Єлисаветградської округи в Зінов'євську округу і м. Слисаветграда в м. Зінов' євськ» була ухвалена лише 7 серпня 1924 року (Постановление, 1924a: 447-448), а на рівні СРСР лише 5 вересня, в місті та окрузі розпочалася підготовка до масового святкування 3 нагоди набуття містом «революційної назви».

Уже 10 липня газета «Червоний шлях» вперше задекларувала, що вона виходить у Зінов'євську, а не в Єлисаветі-Слисаветграді (Чорний, 2019: 227-228). Тоді ж видання повідомило, що ВУЦВК «схвалив перейменування міста Єлисаветграда в Зінов'євськ і Єлисаветградської округи в Зінов'євську» (ВУЦИК утвердил, 1924: 1) та представило програму святкування (Празднование переименования, 1924: 1).

12 липня 1924 року в театрі заводу «Червона Зірка» відбулися урочисті збори, на яких з гарячими промовами виступили голова окружного виконавчого комітету КП(б)У Г. П. Радченко, очільник окружного комітету КП(б)У П. П. Амосов та голова комісії з перейменування міста М. К. Іванов. Доповідачі «по-більшовицьки», «по-революційному» говорили про важкі часи робітничого 
класу і селянства краю, про пролетарську революцію та світле майбутнє, про «полум'яного» революціонера й учня товариша Леніна - Григорія Овсійовича Зінов'єва, на честь якого перейменоване місто. Наприкінці зборів усі присутні ухвалили направити вітальну телеграму на ім'я винуватця торжества, а також за пропозицію М. К. Іванова одноголосно обрали Г. О. Зінов'єва «почесним головою окрвиконкому та членом міської ради» (К переименованию, 1924с: 2). Закриваючи збори, присутні поклялися «строго виконувати заповіти вождя т. Леніна та його учня т. Зінов’єва».

Того ж дня в місті вийшов спецвипуск газети «Червоний шлях», але був він присвячений не Г. О. Зінов'єву, а перейменуванню. Видання не змогло зібрати унікальних свідчень про «славного уродженця міста», а тому обмежилося лише розміщенням його фото (Тов. Г. О. Зиновьев, 1924: 2). У газеті за 12 липня були надруковані матеріали, підготовлені окружним агітпропом для уславлення нової назви. Оцінюючи в цілому опубліковане у спецвипуску, маємо констатувати, що матеріал був дуже низької якості, не розрахований на високоінтелектуального читача. Оскільки всі дописи однотипні, ми не будемо давати їм детальної характеристики. Дозволимо лише навести розлогу цитату з однієї статті, зберігаючи мову оригіналу (російську) аби показати рівень партійних функціонерів міста, а також передати дух та атмосферу, в яких проходив процес перейменування та святкування «народження нового імені». Отож, бачення ініціаторів перейменування проблеми було таким: «Ряд советских городов постепенно меняли свои названия. Вместо Екатеринослава теперь - Красноднепровск, вместо Александровска - Запорожье, Екатеринодара - Краснодар, Петрограда Ленинград и т. д. Неумолимой рукой революционного народа вычеркиваются имена царей и цариц, угнетавших и издевавшихся над народами России.

Почему-то наш Елисаветград оставался Елисаветградом. Неужели Елисавета была лучше Екатерины, которую поэт Шевченко назвал в своём произведении просто и образно - сукой. Елизавета нисколько не уступала Екатерине, с той лишь разницей, что была глупее. 15 тысяч платьев и самые разнообразные сборища любовников от сына укринского дьячка Разумовского до простых гвардейцев - вот в чем заключался весь смысл жизни этой царицы.

Было бы грустно и смешно если-бы впредь название города оставалось старым. Наш город дал Зиновьева, вождя мирового революционного движения; Цюрупу - зампредсовнаркома. Из нашего округа вышел Троцкий, вождь Красной армии; родился виднейший пролетарский поэт Демьян Бедный. Наш город и округ имеет имена которыми может гордиться. К чёрту развратницу Елисавету. Елисаветград, как название города вычеркнуто из географических карт СССР.

Старый Елисаветград дворянский и купеческий вместе с юнкерами перестал существовать после Октябрьской революции. Только название города по прежнему как-то безтолково мозолило глаза и, ясно, как к такому наследию не прибавить эпитеты вроде «Елдыбеш», «Елисаветгроб».

Зиновьевск бьёт разруху, восстанавливает промышленность, выходит на широкую дорогу экономического и культурного наследия» (Кремнев, 1924: 2). 
Кілька днів газета «Червоний шлях» публікувала матеріали про те, як «усі трудящі» святкували перейменування. Ось як це описує кореспондент видання А. Арбенін (цитату наводимо мовою оригіналу аби повною мірою передати атмосферу свята): «В субботу 12 июля окончательно похоронено слово «Елисаветград». Народился новый город, город пролетарской вольницы Зиновьевск. Стройными колонами двигается Зиновьевский пролетариат по своему городу. С расцвеченными ало-красными знамёнами, с портретами вождей революции, при оркестрах музыки проходят манифестирующие массы перед зданием партийного комитета. В речах ораторов слышны горячие призывы - строить ещё дружнее новую жизнь. В ответ несётся раскатистое «ура» тысячной массы. Город принял праздничный вид, принарядился. Госучреждения убраны красной материей, в рамках которых - наши вожди. Ночью горят электрические звёзды. У Краснозвёздовцев торжественный пленум горсовета, посвящённый тов. Зиновьеву и Зиновьевску. Во всех клубах торжественные праздничные спектакли. Всюду слышится живое слово о живом вожде. Старый город умер... Над Елисаветградом вбит осиновый кол. Будем достойны носить имя т. Зиновьева, - сказал один из рабочих приветствовавший манифестирующих. «Будем достойны» - ответили все. Так оно и будет! Ибо у пролетария что ни слово, то дело. Пусть живёт т. Зиновьев, Зиновьевск и Зиновьевцы!» (Арбенин, 1924: 2).

Аби довершити святкування та ще більше увічнити Г. О. Зінов'єва, у місті його імені вирішили перейменувати вулицю Михайлівську на вулицю Григорія Зінов'єва. До речі, вулиця свою першоназву носила 3 моменту іiі закладення у середині XVIII століття. Також окружними та міськими партійними органами було вирішено зробити в подальшому дату перейменування міста (12 липня) вихідним днем для трудящих Зінов'євська.

18 липня 1924 року Г. О. Зінов’ єв особисто привітав містян телеграмою, у якій зазначив, що через велику зайнятість не зміг особисто прибути на святкування перейменування та констатував, що вбачає у зміні назви міста «растущую мощь и внимание коммунистической партии и беспредельную любовь со стороны трудящихся масс к ней, готовых на величайшие акты самопожертвования во имя пролетарской революции» (Телеграмма, 1924: 2).

Продовжуючи вимітати «мітлою трудового народу» стару назву з міста, 19 липня 1924 року ВУ ЦВК УСРР порушив клопотання перед ЦВК СРСР про перейменування станції Єлисаветград в станцію Зінов' євськ (По Советскому Союзу, 1924: 2). 22 листопада 1924 року ЦВК СРСР видав постанову про перейменування (Переименование, 1924: 4). На початку жовтня 1924 року Зінов’ євський окружний виконавчий комітет прийняв рішення зберегти дім, в якому в єлисаветградський період життя проживав Г. О. Зінов'єв (Дом, 1924: 4). Будинок було передано у підпорядкування міської організації політпросвіти ймовірно для подальшої музеєфікації. Як бачимо, після перейменування постать живого вождя у Зінов'євську була увічнена за кращими лекалами i традиціями більшовицької пропаганди.

Через рік все та ж газета «Червоний шлях» писала, що містяни будуть 3 гордістю носити ім'я «товариша Зінов'єва», що старе вже ніколи не 
повернеться, що всі трудящі міста - зінов'євці.

23 березня 1926 року Г. О. Зінов’єв був знятий 3 посади голови Ленінградської ради робітничих, селянських та червоноармійських депутатів (Зиновьев, 1990: 96), а 23 липня того ж року виведений з членів Політбюро ЦК ВКП(б) та усунений 3 посади Голови Комінтерну. Це стало наслідком внутрішньопартійної боротьби, у якій Г.О. Зінов’ єв програв Й В. Сталіну (Васецкий, 1989: 120).

Партійна номенклатура Зінов’ євська належним чином відреагувала на початок падіння «кращого учня Леніна i палкого ленінця». Уже в липні 1926 року засоби масової інформації міста жодним словом не згадали про «живого вождя», а партійна верхівка округу і міста започаткувала обговорення можливості перейменування міста в «нову революційну» назву. Як варіант нової назви пропонувалося увічнити Ф. Е. Дзержинського та перейменувати місто в Дзержинськ (Пасічник, 2012: 12). Нову назву місто отримало 1934 року, коли після смерті С. М. Кірова місто Зінов'євськ було перейменоване в Кірово, а 1939 року - в Кіровоград.

Висновки. Реконструкція та аналіз подій щодо зміни назви міста Єлисаветграда в 1924 році засвідчує, що перейменування стало результатом політики радянізації топонімії в СРСР, яка активно стартувала після смерті більшовицького вождя В. І. Леніна. Перейменування Єлисаветграда в Зінов'євськ відбулося завдяки активним діям окружного та міського осередків КП(б)У, які, кулуарно вирішивши якою має бути нова назва міста, переконали «трудящі маси» в тому, що це їхній вибір і що увічнення Г. О. Зінов'єва - це запорука успіху «нового пролетарського» міста у майбутньому. Перейменування Єлисаветграда в Зінов'євськ стало другим випадком в історії УСРР, коли географічний об'єкт було названо на честь ще живого, але не вічного вождя. Падіння Г. О. Зінов’єва спричинило повторні перейменування міста у 1934 та 1939 роках, що безумовно позначилося і на його історії, i на міській топоніміці.

\section{СПИСОК ВИКОРИСТАНИХ ДЖЕРЕЛ І ЛІТЕРАТУРИ}

Агітпроп, 1924 - Агитпроп. К переименованию г. Елисаветграда в Зиновьевск // Червоний шлях. 1924. 21 червня. С. 2.

Амосов, 1924 - Амосов П. Окружная партконференция // Червоний илях. 1924. 23 квітня. С. 1.

Арбенин, 1924 - Арбенин А. Зиновьевск // Червоний илях. 1924. 15 липня. С. 2.

Васецкий, 1989 - Васецкий Н. А. Г. Е. Зиновьев: страницы жизни и политической деятельности // Новая $u$ новейшая история. 1989. № 4. С. 111-139.

Вержбиньски, 2012 - Вержбиньски Я. Топонимические советизмы, связанные с именами Ленина и Сталина // Acta Universitatis Lodziensis. Folia linguistica Rossia. Tom 8 (2012). S. 103-111.

Второй, 1924 - Второй съезд советов Союза Советских Социалистических Республик: стенографический очерк. М., 1924. 236 с.

ВУЦИК утвердил, 1924 - ВУЦИК утвердил переименование города Елисаветграда в Зиновьевск и Елисаветградского округа в Зиновьевский // Червоний илях. 1924. 10 липня. С. 1.

ДАКО - Державний архів Кіровоградської області.

Дамбуев, 2015 - Дамбуев И. А. Советское законодательство о наименовании географических объектов // Мир науки, культуры, обозрения. 2015. № 6. С. 290-293.

Дом, 1924 - Дом, где родился Зиновьев // Червоний илях. 1924. 4 жовтня. С. 4.

Заривайко, 1987 - Заривайко Прокіп Авдійович / Великий Жовтень і Громадянська війна на Україні. Енциклопедичний довідник / Відп. ред. І. Ф. Курас. К., 1987. С. 209.

Зиновьев, 1990. - Зиновьев (Радомысльский) Григорий Евсеевич (Евсей-Гершен Аронович) // Известия 
ЦК КПСС. 1990. № 7. С. 96.

Історія, 1972 - Історія міст і сіл УРСР. Кіровоградська область. К., 1972.816 с.

К переименованию, 1924а - К переименованию г. Елисаветграда // Червоний илях. 1924. 22 червня. С. 3.

К переименованию, 1924b - К переименованию Елисаветграда в Зиновьевск. Как был переименован наш город. Беседа с Секретарем Окружного партийного комитета тов. Амосовым // Червоний шлях. 1924. 12 липня. С. 2.

К переименованию, 1924c - К переименованию Елисаветграда. Торжественное заседание представителей партийных, профсоюзных и советских организаций // Червоний шлях. 1924. 15 липня. С. 2.

Коммунистический, 1969 - Коммунистический Интернационал. Краткий исторический очерк. М., 1969. 600 с.

Кремнев, 1924 - Кремнев М. Прежде и теперь // Червоний шллхх. 1924. 12 липня. С. 2.

Матівос, 2004 - Матівос Ю. М. Місто на Сивому Інгулі: Історико-публіцистичний нарис. Кіровоград, 2004.

296 c.

Открытие, 1924 - Открытие 8-й Окружной партконференции // Червоний илях. 1924. 24 квітня. С. 2.

Пасічник, 2012 - Пасічник Л. М. Від Єлисаветграда до Кіровограда // Вечірня газета. 2012. 28 грудня. С. 12.

Переименование, 1924 - Переименование станции Елисаветград // Червоний илях. 1924. 22 листопада. С. 4.

По Советскому Союзу, 1924 - По Советскому Союзу. О переименовании станции Елисаветград // Червоний шлях. 1924. 19 липня. С. 2.

Постановление, 1924а - Постановление Всеукраинского Центрального Исполнительного Комитета от 7 августа 1924 года "О переименовании Елисаветградского округа в Зиновьевский округ и гор. Елисаветграда в гор. Зиновьевск" // Собрание узаконений и распоряжений Рабоче-Крестьянского Правительства Украины. 1924. № 20. C. 447-448.

Постановление, 1924b - Постановление Президиума ЦИК Союза ССР от 6 июня 1924 г. «О переименовании г. Юзовки, Округа Юзовского и ст. Юзово» // Вестник Центрального Исполнительного Комитета, Совета Народныхх Комиссаров и Совета Труда и Обороны Союза ССР. 1924. № 6. С. 199.

Празднование переименования, 1924 - Празднование переименования Елисаветграда // Червоний шлях. 1924. 10 липня. С. 1.

От редакции, 1924а - От редакции // Червоний илях. 1924. 10 червня. С. 1.

От редакции, 1924b - От редакции // Червоний шлях. 1924. 11 червня. С. 1.

От редакции, 1924c - От редакции // Червоний шлях. 1924. 12 червня. С. 1.

От редакции, 1924d - От редакции // Червоний шлях. 1924. 13 червня. С. 1.

Телеграмма, 1924 - Телеграмма от т. Зиновьева // Червоний шлях. 1924. 19 липня. С. 2.

Тов. Г. О. Зиновьев, 1924 - Тов. Г. О. Зиновьев // Червоний илях. 1924. 12 липня. С. 2.

Шалаева, 2013 - Шалаева Н. Проблемы культа личности В. И. Ленина (историографический анализ) // Власть. 2013. № 5. C. 104-108.

Шевченко, 1988 - Шевченко С. Слисаветград-Зінов’євськ-Кірово // Молодий комунар. 1988. 17 вересня. С. 6-7. Чорний, 2019 - Чорний О. В. Слисавет: походження назви та історія ії вживання (1755-1924) // Наукові записки. Серія: Історичні науки. Випуск 25. Кропивницький, 2019. С. 214-246.

\section{REFERENCES}

Agitprop, 1924 - Agitprop. K pereimenovaniyu g. Yelisavetgrada v Zinov'yevsk [To Renaming the city of Elisavetgrad to Zinovievsk] // Chervonyy shlyakh. 1924. 21 chervnya. S. 2. [in Russian].

Amosov, 1924 - Amosov P. Okruzhnaya partkonferentsiya [The District Party Conference] // Chervonyy shlyakh. 1924. 23 kvitnya. S. 1. [in Russian].

Arbenin A. Zinov'yevsk [Zinov'yevsk] // Chervonyy shlyakh. 1924. 15 lypnya. S. 2. [in Russian].

Vasetskiy, 1989 - Vasetskiy N. A. G. Ye. Zinov'yev: stranitsy zhizni i politicheskoy deyatel'nosti [G. E. Zinoviev: pages of life and political activity] // Novaya i noveyshaya istoriya. 1989. № 4. S. 111-139. [in Russian].

Verzhbin'ski, 2012 - Verzhbin'ski Ya. Toponimicheskiye sovetizmy, svyazannyye s imenami Lenina i Stalina [Toponymic sovietisms connected with the names of Lenin and Stalin] // Acta Universitatis Lodziensis. Folia linguistica Rossia. Tom 8 (2012). S. 103-111. [in Russian].

Vtoroy, 1924 - Vtoroy s"yezd sovetov Soyuza Sovetskikh Sotsialisticheskikh Respublik: stenograficheskiy ocherk [Second Congress of Soviets of the Union of Soviet Socialist Republics: a shorthand sketch]. M., 1924. 236 s. [in Russian].

VUTSIK utverdil, 1924 - VUTSIK utverdil pereimenovaniye goroda Yelisavetgrada $\mathrm{v}$ Zinov'yevsk i Yelisavetgradskogo okruga v Zinov'yevskiy [The All-Ukrainian Central Executive Committee approved the renaming of the city of Elisavetgrad into Zinovievsk and the Elisavetgrad district into Zinovievsk district] // Chervonyy shlyakh. 1924. 10 lypnya. S. 1. [in Russian].

DAKO - Derzhavnyy arkhiv Kirovohrads'koyi oblasti [State archive of Kirovohrad region]. [in Ukrainian].

Dambuyev, 2015 - Dambuyev I. A. Sovetskoye zakonodatel'stvo o naimenovanii geograficheskikh ob"yektov [Soviet legislation on geographical names] // Mir nauki, kul'tury, obozreniya. 2015. № 6. S. 290-293. [in Russian].

Dom, 1924 - Dom, gde rodilsya Zinov'yev [The house where Zinoviev was born] // Chervonyy shlyakh. 1924. 4 zhovtnya. S. 4. [in Russian]. 
Zaryvayko, 1987 - Zaryvayko Prokip Avdiyovych [Zaryvayko Prokip Avdiyovych] / Velykyy Zhovten' i Hromadyans'ka viyna na Ukrayini. Entsyklopedychnyy dovidnyk / Vidp. red. I. F. Kuras. K., 1987. S. 209. [in Ukrainian].

Zinov'yev, 1990 - Zinov'yev (Radomysl'skiy) Grigoriy Yevseyevich (Yevsey-Gershen Aronovich) [Zinov'yev (Radomysl'skiy) Grigoriy Yevseyevich (Yevsey-Gershen Aronovich)] // Izvestiya TsK KPSS. 1990. № 7. S. 96. [in Russian].

Istoriya, 1972 - Istoriya mist i sil URSR. Kirovohrads'ka oblast'. [The History of cities and villages of the USSR. Kirovograd region]. K., 1972. 816 s. [in Ukrainian].

K pereimenovaniyu, 1924a - K pereimenovaniyu g. Yelisavetgrada [To rename Elisavetgrad] // Chervonyy shlyakh. 1924. 22 chervnya. S. 3. [in Russian].

K pereimenovaniyu, 1924b - K pereimenovaniyu Yelisavetgrada v Zinov'yevsk. Kak byl pereimenovan nash gorod. Beseda s Sekretarem Okruzhnogo partiynogo komiteta tov. Amosovym [To rename Elisavetgrad to Zinovievsk. How our city was renamed. Conversation with the Secretary of the District Party Committee comrade Amosov] // Chervonyy shlyakh. 1924. 12 lypnya. S. 2. [in Russian].

$\mathrm{K}$ pereimenovaniyu, 1924c - K pereimenovaniyu Yelisavetgrada. Torzhestvennoye zasedaniye predstaviteley partiynykh, profsoyuznykh i sovetskikh organizatsiy [To rename Elisavetgrad. Solemn meeting of representatives of party, trade union and Soviet organizations] // Chervonyy shlyakh. 1924. 15 lypnya. S. 2. [in Russian].

Kommunisticheskiy, 1969 - Kommunisticheskiy Internatsional. Kratkiy istoricheskiy ocherk [Communist International. A brief historical outline]. M., 1969. 600 s. [in Russian].

Kremnev, 1924 - Kremnev M. Prezhde i teper' [Before and now] // Chervonyy shlyakh. 1924. 12 lypnya. S. 2. [in Russian].

Mativos Yu. M. Misto na Syvomu Inhuli: Istoryko-publitsystychnyy narys [The city on the Gray Ingul: Historical and journalistic essay]. Kirovohrad, 2004. 296 s. [in Ukrainian].

Otkrytiye, 1924 - Otkrytiye 8-y Okruzhnoy partkonferentsii [Opening of the 8th District Party Conference] // Chervonyy shlyakh. 1924. 24 kvitnya. S. 2. [in Russian].

Pasichnyk, 2012 - Pasichnyk L. M. Vid Yelysavethrada do Kirovohrada [From Yelisavetgrad to Kirovograd] // Vechirnya hazeta. 2012. 28 hrudnya. S. 12. [in Ukrainian].

Pereimenovaniye, 1924 - Pereimenovaniye stantsii Yelisavetgrad [Renam of Elisavetgrad station] // Chervonyy shlyakh. 1924. 22 lystopada. S. 4. [in Russian].

Po Sovetskomu, 1924 - Po Sovetskomu Soyuzu. O pereimenovanii stantsii Yelisavetgrad [Across the Soviet Union. About renaming Elisavetgrad station] // Chervonyy shlyakh. 1924. 19 lypnya. S. 2. [in Russian].

Postanovleniye, 1924a - Postanovleniye Vseukrainskogo Tsentral'nogo Ispolnitel'nogo Komiteta ot 7 avgusta 1924 goda «O pereimenovanii Yelisavetgradskogo okruga v Zinov'yevskiy okrug i gor. Yelisavetgrada v gor. Zinov'yevsk» [Resolution of the All-Ukrainian Central Executive Committee of August 7, 1924 «On renaming the Elisavetgrad district into the Zinovievsky district and the mountains. Elisavetgrad in the mountains. Zinovievsk»] // Sobraniye uzakoneniy i rasporyazheniy Raboche-Krest'yanskogo Pravitel'stva Ukrainy. 1924. № 20. S. 447-448. [in Russian].

Postanovleniye, 1924b - Postanovleniye Prezidiuma TsIK Soyuza SSR ot 6 iyunya 1924 g. «O pereimenovanii g. Yuzovki, Okruga Yuzovskogo i st. Yuzovo» [Resolution of the Presidium of the Central Executive Committee of the USSR dated June 6, 1924 «On renaming the town of Yuzovka, Yuzov District and station Yuzovo »] // Vestnik Tsentral'nogo Ispolnitel'nogo Komiteta, Soveta Narodnykh Komissarov i Soveta Truda i Oborony Soyuza SSR. 1924. № 6. S. 199. [in Russian].

Prazdnovaniye pereimenovaniya, 1924 - Prazdnovaniye pereimenovaniya Yelisavetgrada [Celebration of renaming of Elisavetgrad] // Chervonyy shlyakh. 1924. 10 lypnya. S. 1. [in Russian].

Ot redaktsii, 1924a - Ot redaktsii [From the editorial board] // Chervonyy shlyakh. 1924. 10 chervnya. S. 1. [in Russian].

Ot redaktsii, 1924b - Ot redaktsii [From the editorial board] // Chervonyy shlyakh. 1924. 11 chervnya. S. 1. [in Russian].

Ot redaktsii, 1924c - Ot redaktsii [From the editorial board] // Chervonyy shlyakh. 1924. 12 chervnya. S. 1. [in Russian].

Ot redaktsii, 1924d - Ot redaktsii [From the editorial board] // Chervonyy shlyakh. 1924. 13 chervnya. S. 1. [in Russian].

Telegramma, 1924 - Telegramma ot t. Zinov'yeva [The telegram from Comrade Zinoviev] // Chervonyy shlyakh. 1924. 19 lypnya. S. 2. [in Russian].

Tov. G. O. Zinov'yev, 1924 - Tov. G. O. Zinov'yev [Comrade G. O. Zinoviev] // Chervonyy shlyakh. 1924. 12 lypnya. S. 2. [in Russian].

Shalayeva, 2013 - Shalayeva N. Problemy kul'ta lichnosti V. I. Lenina (istoriograficheskiy analiz) [Problems of the personality cult of V. I. Lenin (historiographic analysis)] // Vlast'. 2013. № 5. S. 104-108. [in Russian].

Shevchenko, 1988 - Shevchenko S. Yelysavethrad-Zinov"yevs'k-Kirovo [Yelysavethrad-Zinov"yevs'k-Kirovo] // Molodyy komunar. 1988. 17 veresnya. S. 6-7. [in Ukrainian].

Chornyi, 2019 - Chornyi O. V. Yelysavet: pokhodzhennya nazvy ta istoriya yiyi vzhyvannya (1755-1924) [Yelisavet: The origin of the name and the history of its application (1755-1924)] // Naukovi zapysky. Seriya: Istorychni nauky. Vypusk 25. Kropyvnyts'kyy, 2019. S. 214-246. [in Ukrainian]. 


\author{
олена ДУДНИк, \\ orcid.orq / 0000-0003-1013-1170 \\ кандидат історичних наук, \\ Уманського державного педагогічного \\ університету імені Павла Тичини \\ (Україна, Умань) \\ dudnyk_olena@ukr.net
}

\title{
«ПРОСВІТА» УМАНЩИНИ ЗА ЧАСІВ УКРАЇНСЬКОЇ ЦЕНТРАЛЬНОЇ РАДИ
}

\begin{abstract}
Події Украӥнської революиії 1917-1921 рр. сприяли заснуванню просвітницьких організацій, які своїм основним завданням вбачали надання різної допомоги населенню на ниві культурно-освітніх справ. У статті досліджується прочес утворення товариств «Просвіта» в Уманському повіті Київської губернії. 3 огляду на вагомість реалізованих проектів в статті увага присвячена добі Центральної Ради.

Базуючись на архівних документах та матеріалах періодики, з'ясовано, щзо організаційні заходи $з$ відродження просвітницького руху в Київькій губернії були започатковані відразу після зміни політичного режиму. Головну увагу «Просвіти» краю приділяли праці в українських селах. У публікації встановлено, щзо просвітнищькі організації в повіті почали виникати завдяки народній ініціативі, передусім проявам організаційних зусиль національно налаштованої місцевої інтелігенції та сільської молоді. Встановлено, щзо у більшості сіл Уманського повіту «Просвіти» виступали єдиними структурами, які проводили активну роботу серед населення, їх діяльність фокусувалася у культурнищькій і освітній площчні. Одним із головних завдань, щзо стояли перед просвітянами, було відкриття власних книгозбірень або бібліотек-читалень, придбання літератури $і$ періодичних видань, організачія курсів украӥнознавства, поширення освітніх знань серед населення тобто все те, щзо могло сприяти пробудженню національної свідомості украйнців краю та їх об'єднанню. Фінансова допомога просвітянам краю надавалася органами місцевої влади, самоврядувань, окремими громадянами.
\end{abstract}

Ключові слова: «Просвіта», Уманський повіт, Київьька губернія, культурно-освітня політика, Центральна Рада.

Olena DUDNYK, PhD in History,

Pavlo Tychyna Uman State Pedagogical University (Ukraine, Uman) dudnyk_olena@ukr.net

\section{«PROSVITA» IN THE UMAN COUNTIE DURING THE UKRAINIAN CENTRAL RADA}

The events of the Ukrainian Revolution of 1917-1921 contributed to the establishment of educational organizations, whose main task was to provide various assistance to the population in cultural and educational affairs. The article examines the formation of «Prosvita» societies, their number in the Uman countie of Kyiv province The southern lands of Kyiv region served as a cradle in the formation of the Ukrainian national liberation movement in the historical destiny of Ukraine. The article focuses on the era of the Central Council taking into consideration the importance of the implemented projects. Based on archival documents and periodicals, it was found that organizational measures to revive the educational movement in countiei of Kyiv province had been initiated immediately after the change of political regime. The main attention of "Prosvita" in the region was paid to works in Ukrainian villages. The publication finds that educational organizations in the region began to emerge due to popular initiative, primarily manifestations of organizational efforts of nationally oriented local intelligentsia (teachers, officials) and rural youth. Well-known public figures provided practical assistance in the development of the educational movement. The cultural and educational work of educational societies in the province was especially intensified after the proclamation of the First Universal of the Central Rada and the All-Ukrainian Congress of Societies (June 1917). It was stated that "Prosvitas» were the only structures that carried out active work among the population, their activities were focused on the cultural and educational level in most villages of the Uman countie of the Kyiv province.An important and logical of work of the "Prosvita» of social and educational life of Uman region was the organization of courses in Ukrainian 
studies. the lask of Ukrainian textbooks hampered the ukrainianzation of the scool so members of the «Prosvita» took an aktivte part in creating educational and methodological support for educational institutions/ One of the main tasks facing the educators was to open their book collections or reading libraries, purchase literature and periodicals, organize courses in Ukrainian studies, disseminate educational knowledge among the population, i.e. everything that could help awaken the national consciousness of Ukrainians in the region. Financial assistance to the educators of the region was provided by local authorities and governments, and individual citizens.

Key words: «Prosvita», Uman countie, Kyiv province, cultural and educational policy, Central Rada.

Постановка проблеми. Революційні події 1917-1921 pp. сприяли суттєвим національно-демократичним перетворенням у різних сферах суспільного та культурно-освітнього життя України. Важливою частиною суспільного життя українців в добу Української революції була діяльність культурно-просвітніх самоврядних організацій. Своєрідним центром національно-культурного відродження в добу Української Центральної Ради стала культурно-просвітницька благодійна організація «Просвіта».

Повноцінне духовне відродження народу не можна уявити без вивчення історії окремих регіонів, міст і сіл. Реконструкція національно-демократичних перетворень у революційну добу вимагає активізації регіональних досліджень в українській історії. Тому зростає потреба звернутися до досвіду організації і діяльності просвітянського руху в Київській губернії, зокрема в Уманському повіті. Адже цей досвід має для сучасної України не лише наукове, але й практичне значення. Врахування уроків минулого, засвоєння всього цінного i повчального має важливе значення для сучасного державотворення, утвердження демократичних принципів розвитку суспільства.

Аналіз досліджень. Факти про діяльність «Просвіт», їхню роль у становленні культурно-освітнього сегменту української державності в добу національно-визвольних змагань 1917-1921 pр. знаходимо в працях і спогадах безпосередніх учасників революційних подій (В. Винниченка, Д. Дорошенка та ін.) (Винниченко, 1990; Дорошенко, 2007). Певне значення для аналізу діяльності «Просвіти» в революційний час мають синтетичні роботи В. Верстюка (Верстюк, 2004), Я. Грицака (Грицак, 1996), О. Реєнта (Реєнт, 2003), В. Сарбея (Сарбей, 1999) та ін. Частково дослідженням із вказаної проблематики присвячені праці сучасних вітчизняних дослідників - С. Фарини (Фарина, 1993), О. Германа (Герман, 1995), Л. Кравчука (Кравчук, 1996), Т. Осташко (Осташко, 1997) та ін. Зазначені вчені у своїх роботах відводять вагоме місце ролі просвітницьких осередків у національно-демократичних перетвореннях українського народу, аналізують процес утворення «Просвіт» у різних регіонах держави, розкривають форми і методи культурно-освітньої праці просвітян.

Одним з напрямків подальших досліджень може бути заглиблення аналізу просвітянського руху на первинний, локальний рівень його діяльності. Діяльність товариств «Просвіта» на території Київської губернії після Лютневої революції 1917 р. і досі лишається однією з малодосліджених сторінок історії українського національно-культурного руху.

Мета статті. Метою цієї статті $\epsilon$ аналіз розвитку просвітницького руху в Уманському повіті Київської губернії в період Центральної Ради, який базується на архівних документах та матеріалах періодики. 
Виклад основного матеріалу. Паралельно з розгортанням Української революції набирало сили національно-культурне відродження українського народу. Найбільшого впливу на державотворчі процеси в гуманітарній сфері товариства «Просвіта» досягли в початковий період революції, який уособлювався із структурами і діяльністю Української Центральної Ради. В добу Центральної Ради в містечках та селах Уманського повіту Київської губернії відновлювалися та створювалися осередки «Просвіт», які мали суттєвий вплив на розвиток національної освіти і культури в краю. Так, 8 березня 1917 р. у відозві Товариства українських поступовців «До українського громадянства» був заклик: «Відживляйте і засновуйте «Просвіти» й інші товариства, бо в них осередок культурної праці та початок організації наших сил» (Адамський, 2018: 5).

В Київської губернії осередки «Просвіт» закладаються вже в квітні 1917 р. Головну увагу «Просвіти» приділяли праці в українських селах. Це було дуже важливо в справі відродження національної справи, оскільки в соціальній структурі українського суспільства селянство становило виняткову більшість. Тому стояло завдання залучити широкий загал сільського населення до вирішення проблем національно-визвольної боротьби. На думку В. Лозового, основною організаційною формою залучення селянства до участі в державотворчому процесі мали стати товариства «Просвіта» (Лозовий, 2006: 3).

У квітні 1917 р. розпочала свою діяльність «Просвіта» в селі Ягубець Уманського повіту. Голова товариства Юстим Велічко передусім звернувся до молоді, яка закінчила або ж навчалася у двокласній школі, із розповіддю про завдання «Просвіти». Молодь села згодилася брати участь у діяльності освітньо-просвітницької організації. Записалися до складу «Просвіти» і літні люди. Було зібрано понад 200 книг, які зберігалися у громадській хаті, виписали газети «Нова Рада», «Народна воля», «Вільна Україна» та інші. В роботі товариства взяли участь 173 його члени. Вони збиралися вечорами у громадській хаті, читали газети, дискутували 3 політичних питань. Для неписьменного дорослого населення влаштовано вечірні курси, на яких вчили писати і читати (ДАКО. Ф. 1. Опис 398. Спр. 8. 17 арк. Арк. 3).

Особливо активізувалася культурно-освітня робота просвітницьких товариств після Всеукраїнського з'їзду товариств (червень 1917 р.), який висунув перед місцевими організаціями таке завдання - прискорити створення бібліотек, клубів, читалень, надавати всебічну допомогу в організації українських початкових шкіл для дітей, курсів ліквідації неписьменності для дорослих та підвищення освітнього рівня військовослужбовців. 20 червня на засіданні п'ятої сесії Центральної Ради делегат від Уманщини Олександр Ільченко повідомляв: «Після відчитання Універсалу на вірність ЦУР присягнули полк, народ і духовенство...Свідомість серед народу шириться. Число «Просвіт» росте» (Вісті з Української Центральної Ради, 1917: 2).

Завдяки народній ініціативі просвітницькі організації почали виникати по всій губернії. Періодичні видання того часу є досить інформативним джерелом щодо розгортання просвітянського руху на місцях. Зокрема, газета «Нова рада» оперативно подавала відомості про створення і активну роботу осередків 
«Просвіти» на Уманщині. 3 цього джерела маємо дані про заснування «Просвіти» протягом червня-вересня 1917 р. у таких селах Уманського повіту: Дмитрушки, Молодецьке (Вісті з краю..., 1917), Юрполе, Папужинці, Беринка, Лащева, та Кам'янече, Соколовка («Просвіта»сві, 1917), Покотилове (Читальня, 1917), а також у містечку Тальне (очолив місцевий вчитель I. Галай) (29 червня в м. Тальному, 1917).

В липневому номері газети «Нова рада» повідомлялося: «В селі Павловці Уманського повіту на Київщині в земській школі засновано товариство «Просвіта». За два дні записалося 70 членів, котрі внесли 30 карбованців грошей. На ці гроші виписано «Вільну Україну», накуплено найпотрібніших книжок. До «Просвіти» записалися тільки молоді сили, котрі з великою охотою приступили до праці... Запис членів 3 кожним днем збільшується» (В с. Павловці..., 1917).

У вересні 1917 року в Київській губернії вже діяло 222 осередки, з них: 69 - в Уманському повіті.

Просвітницькою діяльністю у повітах займалися $\mathrm{i}$ інструктори губернського інформаційного бюро. В Київській губернії працювало 54 інструктори, 3 них 10 - в Уманському повіті. Інструктори поширювали літературу серед населення, організовували мітинги та лекції (Інформаційне бюро при Київській Губернській Земській Управі, 1917).

1 жовтня 1917 року в приміщенні політичного клубу м. Умані відбулися установчі збори членів товариства «Просвіта». Учасники зборів заслухали i обговорили доповідь про основні завдання, схвалили статут та обрали раду товариства. До правління товариства увійшли: М. Крамаренко, 3. Краковецький, В. Шпігель, Ю. Дуброва, В. Цєшковський, М. Піснячевський, О. Мущинський. Головою ради обрали Ф. Ловецького, писарем - С. Іваненка, скарбником - К. Малюшевича. Метою своєї діяльності просвітяни Уманщини визначили: заснувати в місті, селах і містечках повіту українські книгозбірні, провести українізацію місцевих шкіл, влаштовувати для населення вистави, музичні і літературні вечори, лекції, дитячі ранки, тобто все те, що могло сприяти пробудженню національної свідомості українців уманського краю та їх об'єднанню. До складу товариства увійшли 64 особи. Уманська «Просвіта» проводила культурно-просвітницьку роботу серед козаків Маньківки і Канева, влаштовуючи їм лекції і вистави (ЦДАВО України. Ф. 166. Опис 1. Спр. 6. Арк. 62). Товариство проявляло турботу щодо поширення освітніх знань серед населення. 3 цією метою організовувалися курси для дорослих, які працювали в приміщенні чоловічої гімназії. До проведення занять залучалися вчителі середніх шкіл міста, які читали лекції та проводили практичні заняття, що охоплювали спектр знань української мови і граматики, української історії, економічної географії України.

В ці ж дні урочисто відкрито товариство «Просвіта» в селі Верхнячка Уманського повіту. Дали згоду працювати у ньому 30 осіб. У перший же день в селі Ладижинка до «Просвіти» записалися 41 особа, зібрано 91 крб. 96 коп. членських внесків. На ці гроші вирішено передплатити газети та придбати 
українські книжки. За домовленістю бібліотека й читальня розмістилися у місцевій земській школі

Активним членом просвітянської родини Уманщини був В. Дурдуківський - відомий педагог, громадський діяч, один із засновників київської «Просвіти». Володимир Федорович народився в с. Пединівці на Уманщині, у сім'ї священика. Після Української революції став директором Першої української гімназії ім. Т. Шевченка у Києві. В. Дурдуківський підтримував зв'язки з Уманщиною, з іiі громадськими діячами. Він надавав практичну допомогу в становленні «Просвіти» в Умані, надсилав навчальну літературу для учнів та вчителів шкіл повіту.

У доповіді про діяльність Інформаційного бюро при Київській губернській земській управі від 3 вересня 1917 р. зазначалося: «...більше продуктивними виявили себе Селянські Спілки вже через те хоча 6 , що вони об‘ єднують в собі культурно-просвітний, політичний та професіональний елементи, та через те. що у них гуртуються кращі сили села. Просвіти зате виявляють свою діяльність більше усього своїм драматичним відділом i виставами, приносять велику допомогу в поширенню національної ідеї. У Просвітах гуртуються здебільшого богаті селяне і між нами збувають люде, котрі ще недавно були у «Союзі руського народу». Ці люди часто гальмують роботу Просвіт. Взагалі, діяльність Просвіт і Спілок найбільш продуктивна буває там, де на чолі їх стоять інтелігентні сили. На Київщині росповсюдяло Бюро протягом серпня 196.636 українських княжок. Цікаво, що тепер зменшився попит на політично-агітаційні брошури, але зате дуже збільшився попит на шкільні підручники, граматики, популярно-наукові та історичні книжечки» (Інформаційне бюро при Київській Губернській Земській Управі, 1917).

Вагомого значення товариства «Просвіта» надавали бібліотечній та видавничій справам. Практично кожен осередок в повітах Київської губернії долучався до організації власних книгозбірень та відкриття при них читалень.

Важливою подією в культурно-просвітницькому житті населення міста Умані було відкриття у травні 1917 р. міської громадської бібліотеки, яка, за повідомленням газети «Наша бібліотека», відразу ж викликала... наплив читачів і поставила перед правлінням бібліотеки ряд суттєвих і невідкладних завдань.

Ще в кінці 1897 р. за ініціативи місцевої інтелігенції в місті було відкрито громадську бібліотеку-читальню. Це була перша і єдина бібліотека в місті. Однак іiі діяльність проходила у надзвичайно несприятливих умовах. Однією із причин малоефективної діяльності було постійне скорочення асигнувань на їі утримання. У квітні 1914 р. громадськість розпочала збір коштів на зведення власного будинку бібліотеки, добилася виділення земельної ділянки під будівництво. Проте губернатор Київської губернії М. Суковкін своїм розпорядженням призупинив іiї будівництво. I тільки в березні 1917 р. міська дума висловилася за повернення майна бібліотеки колишньому товариству. 1 травня 1917 р. було зірвано печатки і відкрито двері колишнього приміщення, а 25 травня відбулося офіційне відкриття міської громадської бібліотеки, яка упродовж 1917 року значно поповнилась книгами. У іï фонд поступили книги 
колишнього жандармського управління, «Товариства грамотності», яке передало понад 100 книг українською мовою. Фонд нараховував біля 400 українських книжок і 300 журналів. Поповнення бібліотеки проходило за рахунок пожертв різними особами та закладами. Було передано 1540 книг, а присяжні повірені передали 1690 книг i брошур. Працівники бібліотеки підготували новий каталог, було організовано відділ української белетристики, науковий та дитячий відділи. На одному із засідань правління бібліотеки було вирішено придбати книги на єврейській мові для задоволення культурних запитів єврейських читачів. Зросла і загальна чисельність постійних читачів, упродовж семи місяців 3 дня відкриття бібліотеки число читачів зросло до 2505 осіб, з яких майже половину (1160) становили учні.

Важливою й логічною формою роботи товариства «Просвіта» щодо українізації суспільного та освітнього життя Уманщини була організація курсів українознавства. Відсутність українських підручників гальмувала українізацію школи, тому члени товариства «Просвіта» брали активну участь у створенні навчально-методичного забезпечення освітніх закладів.

У добу Центральної Ради товариства «Просвіта» залучали органи державної влади й самі проявляли ініціативу в призначенні на посади вчителів. Уманська «Просвіта» прагнула залучити до педагогічної та культурнопросвітницької діяльності якомога більше вчителів, покладаючи на них важливу роль у розвитку системи української національної освіти та виховання. Безперечно, цей процес не завжди був легким. Самі ж українські свідомі вчителі прагнули брати якнайактивнішу участь у діяльності товариства «Просвіта», оскільки це була справді українська громадська організація, яка намагалася педагогічною та культурно-просвітницькою діяльністю поширити освіту й культуру серед широких верств населення уманського краю.

У час змін суспільно-політичного устрою просвітяни, зазвичай, очолювали шевченківський рух в Україні. Товариство «Просвіта», попри політичну ситуацію, намагалося якомога краще організувати дні пам'яті Великого українського поета. «Просвіти» Уманського повіту у справі піднесення національної свідомості українського народу велику увагу приділяли постаті Т. Шевченка.

Влаштовані просвітянами свята відвідувала значна частина як місцевого населення, так і сусідніх населених пунктів. Так, в Уманському повіті у с. Красний-Кут на такому святі читали реферати про Шевченка, декламували вірші, співали пісні, увечері поставили виставу «Нахмарило». Завершувалися свята роздаванням національно-патріотичної літератури, періодичної преси, зображень Т. Шевченка.

Відзначення шевченківських роковин в добу Української революції 1917 1921 pр. вийшло на якісно новий рівень. Уперше за багато років українці отримали можливість гідно відзначити шевченківські дні. Упродовж майже 150 років шевченківські дні відбувалися часто нелегально; в умовах імперської Росії навіть столітній ювілей було офіційно заборонено відзначати.

Ефективній просвітницькій праці не вистачало фінансового ресурсу. У 1917-1918 pр. «Просвіти» могли покладатися здебільшого на моральну 
підтримку держави, оскільки через важкий фінансовий стан, проблеми 3 державотворенням вона не могла надати їм суттєвої грошової допомоги у здійсненні культурно-освітньої роботи. Утримували просвітянські структури за рахунок кооперативних спілок, добровільних пожертв та членських внесків, розміри яких встановлювали самі просвітяни. На шпальтах тогочасних газет можна відшукати приклади такої допомоги. Так, зокрема «Нова рада» інформувала, що громада і службовці місцевої економії села Шукайвода Уманського повіту на сільському сході постановили заснувати «Просвіту» i бібліотеку. Управитель економії Дамаскин пожертував на книгозбірню 50 крб., бухгалтер - 5 крб., селяни - по 1 крб. Той же управитель пообіцяв на потреби «Просвіти» витратити 3 власних прибутків ще 200 крб. і підтримати ініціативу місцевої вчительки Колосовської щодо створення у селі дитячих ясел «Захоронок» (В Шукайводі, 1917).

Сільський схід села Бабанки цього ж повіту прийняв рішення щодо виділення для роботи місцевого просвітянського осередку 100 крб.

Одним із завдань просвітянських осередків була організація театральної справи. При товариствах утворювалися драматичні гуртки, куди входила місцева інтелігенція та ініціативні селяни; саме вони й репрезентували театральну справу в «Просвітах». В селі Соколівка Уманського повіту просвітяни організували драматичний гурток, який ставив вистави «Москальчарівник», «Бувальщина», «Наталка Полтавка». Просвітяни містечка Тальне за демонстрацію вистави «Батраки» виручили 232 крб. Прибуток використали для поповнення книгозбірні для односельців (Культурно-просвітній гурток..., 1917).

На діяльність товариств значною мірою впливали місцеві умови. «Просвіти» влаштовували різні заходи, щоб збільшити свій бюджет і витрачали кошти лише за потреби.

Висновки. Отже, у добу Центральної Ради осередки товариства «Просвіта» в Уманському повіті стали вагомим чинником провадження на місцях культурно-освітньої політики держави. Якісно іншими стали ознаки суспільно-культурного життя в Україні. Виникнення та поширення «Просвіт» в добу Центральної Ради свідчило про прагнення української інтелігенції до поширення знань серед населення, до пізнання своєї історії, до використання своєї мови. Вперше за сторіччя українська культура вийшла 3 підпілля, українська мова залунала на лекціях, зборах, почали виходити українські книги та газети, були засновані національні школи і дитсадки. У цих проявах зростання національної культури і національної самосвідомості значною $є$ й заслуга «Просвіти» Уманського повіту.

\section{СПИСОК ВИКОРИСТАНИХ ДЖЕРЕЛ І ЛІТЕРАТУРИ}

29 червня в м. Тальному, 1917 - 29 червня в м. Тальному...1917. «Просвіта». Нова Рада. (Киї). 2 липня. Адамський, 2018 - Адамський В. Р. «Просвіти» Поділля в добу Української Центральної Ради (березень 1917 квітень 1918 рр.) : Дослідження. Документи. Матеріали. Хмельницький: ФОП Цюпак А. А., 2018. 478 с. В Шукайводі, 1917 - В Шукайводі... 1917 - «Просвіта». Нова Рада. (Киї). 28 квітня.

Верстюк, та ін., 2004 - Верстюк В., Горобець В., Толочко О. Україна і Росія в історичній ретроспективі. Українські проекти в Російській імперії. К., 2004. 504 с. 
Винниченко, 2007 - Винниченко В. Відродження нації. Репринт. відтвор. вид. 1920 р. : у 3 ч. К. : Вид-во політ. л-ри України, 1990. Ч. III. 542 с.

Герман, 1995 - Герман О. М. Діяльність товариства «Просвіта» на Поділлі наприкінці XIX і в першій половині ХХ століття: дис. ... канд. іст. наук: 07.00.01. Чернівці, 1995. 228 с.

Грицак, 1996 - Грицак Я. Нарис історії України. Формування модерної української нації у XIX-XX ст. К. : Генеза, 1996. 358 с.

ДАКО - Державний архів Київської області.

Дорошенко, 2007 - Дорошенко Д. Мої спомини про недавнє минуле (1914-1920 роки) К. : Темпора, 2007. 632 с. Кравчук, 1996 - Кравчук Л. В. Культуро-творча діяльність та просвітницький рух в період Української державності 1917-1920 рр. : автореф. дис. ... канд. іст. наук: 07.00.01. Чернівці, 1996. 23 с.

Культурно-просвітній гурток, 1918 - Культурно-просвітній гурток...1918. «Просвіта». Нова Рада. (Киї). 25 квітня.

Лозовий, 2006 - Лозовий В. С. Поширення просвітницьких осередків в українському селі в період Центральної Ради (1917 р.). // Освіта, наука і культура на Поділлі: зб. наук. пр. / гол. ред. кол.: П. Т. Тронько. Кам’янецьПодільський: Оіюм, 2006. Т. 7: мат. третього круглого столу «Культура, освіта і просвітницький рух на Поділлі у XVIII - на початку XXI ст.». С. 3-11.

Осташко,1997 - Осташко Т. Товариство «Просвіта» - осередки українського національно-освітнього руху за доби Центральної Ради // Центральна Рада і український державотворчий прочес (до 80-річчя створення Центральної Ради): Матеріали наук. конф., 20 березня 1997 р. НАН України, Ін-т історії України. К., 1997. Ч. 2. С. 272-280.

Реєнт, 2003 - Реєнт О. Україна в імперську добу (XIX - початок XX ст.). К., 2003. 338 с.

Сарбей, 1999 - Сарбей В. Національне відродження України. К., 1999. 335 с.

У містечку Покотилове, 1917 - У містечку Покотилове...1917 - Читальня. Нова Рада. (Київ). 26 червня.

У с. Тихому Хуторі,1917 - У с. Тихому Хуторі...1917 - «Просвіта». Нова Рада. (Київ). 1 жовтня.

Фарина, 1993 - Фарина С. Я. Роль «Просвіт» в українському національно-культурному русі на початку ХХ століття.: дис. ... канд. іст. наук: 07.00.01. Кременчук, 1993. 233 с.

ЦДАВО України - Центральний державний архів вищих органів влади та управління України.

\section{REFERENCES}

29 chervnia v m. Talnomu, 1917 - 29 chervnia v m. Talnomu...1917 [June 29 in Talne ...1917]. «Prosvita». Nova Rada. (Kyiv). 2 lypnia. [in Ukrainian].

Adamskyi, 2018 - Adamskyi V. R. «Prosvity» Podillia v dobu Ukrainskoi Tsentralnoi Rady (berezen 1917 - kviten 1918 rr.) [«Enlightenment» Podillya in the days of the Ukrainian Central Council (March 1917 - April 1918)] : Doslidzhennia. Dokumenty. Materialy. Khmelnytskyi: FOP Tsiupak A. A., 2018. 478 s. [in Ukrainian].

V Shukaivodi, 1917 - V Shukaivodi... 1917 [In Shukaivoda ... 1917] - «Prosvita». Nova Rada. (Kyiv).28 kvitnia. [in Ukrainian].

Verstyuk, ta in., 2004 - Verstiuk V., Horobets V., Tolochko O. Ukraina i Rosiia v istorychnii retrospektyvi. Ukrainski proekty v Rosiiskii imperii [Ukraine and Russia in historical retrospective review. The Ukrainian projects in the Russian empire]. K., 2004. 504 s. [in Ukrainian].

Vynnychenko, 2007 - Vynnychenko V. Vidrodzhennia natsii. Reprynt. vidtvor. vyd. 1920 r. [Revival of the nation]: u 3 ch. K. : Vyd-vo polit. l-ry Ukrainy, 1990. Ch. III. 542 s. [in Ukrainian].

Herman, 1995 - Herman O. M. Diialnist tovarystva «Prosvita» na Podilli naprykintsi XIX I v pershii polovyni XX stolittia [Activities of the society «Enlightenment» in Podolia in the late XIX and early XX century]: dys. ... kand. ist. nauk: 07.00.01. Chernivtsi, 1995. 228 s. [in Ukrainian].

Hrytsak, 1996 - Hrytsak Ya. Narys istorii Ukrainy. Formuvannia modernoi ukrainskoi natsii u XIX-XX st. [Essays on the history of Ukraine: the formation of the modern Ukrainian nation of the XIX-XX centuries]. K.: Heneza, 1996. 358 s. [in Ukrainian].

DAKO - Derzhavnyi arkhiv Kyivskoi oblasti

Doroshenko, 2007 - Doroshenko D. Moi spomyny pro nedavnie mynule (1914-1920 roky) [My memories of the recent past (1914-1920)]. K. : Tempora, 2007. 632 s. [in Ukrainian].

Kravchuk, 1996 - Kravchuk L. V. Kulturo-tvorcha diialnist ta prosvitnytskyi rukh v period Ukrainskoi derzhavnosti 1917-1920 rr. [Cultural activity and educational movement in the period of Ukrainian statehood 1917-1920]: avtoref. dys. ... kand. ist. nauk: 07.00.01. Chernivtsi, 1996. 23 s. [in Ukrainian].

Kulturno-prosvitnii hurtok, 1918 - Kulturno-prosvitnii hurtok...1918 [Cultural and educational circle...1918]. «Prosvita». Nova Rada. (Kyiv). 25 kvitnia. [in Ukrainian].

Lozovyi, 2006 - Lozovyi V. S. Poshyrennia prosvitnytskykh oseredkiv v ukrainskomu seli v period Tsentralnoi Rady (1917 r.) [Dissemination of educational centers in the Ukrainian countryside during the Central Rada (1917)]. Osvita, nauka i kultura na Podilli: zb. nauk. pr. / hol. red. kol.: P. T. Tronko. Kam'ianets-Podilskyi: Oiium, 2006. T. 7: mat. tretoho kruhloho stolu «Kultura, osvita i prosvitnytskyi rukh na Podilli u KhVIII - na pochatku KhKhI st.». S. 3-11. [in Ukrainian]. 
Ostashko,1997 - Ostashko T. Tovarystvo «Prosvita» - oseredky ukrainskoho natsionalno-osvitnoho rukhu za doby Tsentralnoi Rady [Society «Enlightenment» is a center of the Ukrainian national educational movement during the Central Rada] // Tsentralna Rada i ukrainskyi derzhavotvorchyi protses (do 80-richchia stvorennia Tsentralnoi Rady): Materialy nauk. konf., 20 bereznia 1997 r. NAN Ukrainy, In-t istorii Ukrainy. K., 1997. Ch. 2. S. 272-280. [in Ukrainian].

Reient, 2003 - Reient O. Ukraina v impersku dobu (XIX - pochatok XX st.) [Ukraine in the imperial era (XIX - early XX centuries)]. K., 2003. 338 s. [in Ukrainian].

Sarbei, 1999 - Sarbei V. Natsionalne vidrodzhennia Ukrainy [National revival of Ukraine]. K., 1999. 335 s. [in Ukrainian].

U mistechku Pokotylove, 1917 - U mistechku Pokotylove...1917 [In the town of Pokotylove... 1917] - Chytalnia. Nova Rada. (Kyiv). 26 chervnia. [in Ukrainian].

U s. Tykhomu Khutori, 1917 - U s. Tykhomu Khutori...1917 [In the village of Tykhy Khutir] - «Prosvita». Nova Rada. (Kyiv). 1 zhovtnia. [in Ukrainian].

Faryna, 1993 - Faryna S. Ya. Rol «Prosvit»v ukrainskomu natsionalno-kulturnomu rusi na pochatku KhKh stolittia [The role of «Enlightenment» in the Ukrainian national and cultural movement in the early XIX century].: dys. ... kand. ist. nauk: 07.00.01. Kremenchuk, 1993. 233 s. [in Ukrainian].

TsDAVO Ukrainy - Tsentralnyi derzhavnyi arkhiv vyshchykh orhaniv vlady ta upravlinnia Ukrainy.

УДК 94(477.46)"1921/1923":939.52

Ігор ОПАЦЬКИЙ,

orcid.org/0000-0002-6786-3295

кандидат історичних наук, викладач кафедри історіі України

Уманського державного педагогічного університету імені Павла Тичини

(Україна, Умань)

igor.opatskiy@gmail.com

\section{ГОЛОД 1921-1923 РР. НА УМАНЩИНІ (ЗА МАТЕРІАЛАМИ АРХІВУ РОДИНИ КУРІННИХ)}

У статті проаналізовано еgо-документи родини Курінних (передусім щуоденник Петра Федоровича Курінного та особисте листування йог осина Петра Петровича Курінного). Наголошено на основних причинах голоду 1921-1923 рр., його масштаби на території історичної Уманщчини. Результатом наукової розвідки є систематизація відомостей з архіву родини Курінних про голод, основні заходи більшовицької влади зі збору податків, вилучення продовольства у населення, здійснення репресивних заходів у боротьбі з селянським повстанським рухом.

Ключові слова: Уманщчина, голод 1921-1923 рр., Петро Курінний, білошовицький режим, воєнний комунізм.

Ihor OPATSKYI,

Candidate of Historical Sciences, lecturer of history of Ukraine Department Pavlo Tychyna Uman State Pedagogical University

(Uman, Ukraine)

igor.opatskiy@gmail.com

\section{THE FAMINE OF 1921-1923 IN THE UMAN REGION (BASED ON THE MATERIAL FROM THE KURINNYIS FAMILY ARCHIVE)}

The article analyses the ego-documents of the Kurinnyis family (in the first place, Petro F. Kurinnyi's diary and the personal correspondence of his son Petro P. Kurinnyi). The main reasons for the famine of 1921-1923 and its scale on the territory of the historical Uman region are noted. The result of scientific research is the systematization of 
information from the Kurinnyis family archive about the famine, the main measures of the Bolshevik government to collect taxes, the food confiscation from the population and the implementation of repressive measures in order to fight against the peasant insurrectionary movement. The main thesis of the article is a study of the reflection of the theme of the famine of 1921-1923 in the Uman region in the ego-documents of the Kurinnyis family.

The diary entries of Petro F. Kurinnyi (1852 - 1931) for 1921-1922 are analysed, which reflect the main events that led to the famine. In addition to unfavourable weather conditions, the author highlights such measures of the Soviet government that destabilized the situation with the provision of food for the population: exorbitant taxes, contributions, repression of wealthy peasants. These records confirm the opinion that the causes of the famine of 1921-1923 were unfavourable weather conditions and actions of the Soviet government.

The article draws attention to the soaring inflation prior to the monetary reform was introduced. It was recorded that prices in the Uman region grew several times weekly, and the population refused to accept Soviet money. Trading was conducted under a barter system. The most important commodity was grain, which often served as money. In the Uman region, many refugees from starving southern provinces sold various goods in order to buy some food. A large number of exhausted and starving people died in railway cars and at stations where they froze to death without getting any wheat.

Bolsheviks' human resource management is analysed. In particular, it is noted that the Committee of Poor Peasants consisted mainly of people without education and with a dubious background. They implemented the Bolshevik policy in the countryside and conducted the requisition of food. The article reflects how the diet of the Kurinnyis family changed. In particular, it was noted that a previously wealthy family was on the verge of starvation and often did not have the opportunity to purchase food. It is noted that the famine of 1921-1923 had the greatest distribution in the south of Ukraine. However, the Uman region, located near the border with the southern provinces, also suffered from the problem of hunger. Unfavourable weather conditions, unbearable taxes, the requisition of food, the imposition of contributions upon settlements, inflation and other measures of the Soviet government led to the spread of the famine in the Uman region.

Thus, the article traces the reasons for the famine of 1921-1923 based on the analysis of the ego-documents of the Kurinnyis family in the Uman region. Its scale has been determined. The process of exclusion of church values is shown. The spring sowing campaign of 1922 yielded disappointing results. Intensive confiscation of wheat led to the underfulfilment of a sowing-plan. The animal husbandry crisis also reached its climax. The livestock population dropped significantly. That allows us to conclude that the famine of 1921-1923 in the Uman region was caused by the excessive confiscation of wheat and its transfer outside the republic.

Key words: Uman region, famine of 1921-1923, Petro Kurinny, Beloshovytsia regime, military communism.

Постановка проблеми. Голод 1921-1923 pp. офіційно визнавався радянською владою, однак інформацію про нього було спотворено ідеологічною системою. Факт голоду не замовчувався від міжнародної спільноти, однак у 1921 р. голод на Півдні України затінявся інформацією про голод на Поволжі, куди спрямовувалася міжнародна гуманітарна допомога та зерно з голодуючої України. Лише 31922 р. українці почали отримувати продовольчі пайки від гуманітарних місій. Голод 1920-х рр. висвітлювалася радянською історіографією у спрощеному вигляді. Окрім природних чинників та воєнної розрухи мав і соціальні причини, зумовлені економічною політикою більшовицької влади, однак в СРСР ці причини замовчувалися. 3 відновленням незалежності України про політичні та воєнні причини голоду почали з'являтися дослідження вчених, однак у суспільній свідомості катастрофа 19211923 рр. затінялася трагедією Голодомору-геноциду 1932-1933 рр. Традиційно, цьогоріч в Україні відбулися офіційні заходи з вшанування пам'яті жертв Голодоморів, зокрема 100-річчя від початку масового голоду на Півдні України у 1921 р. Вшанування 100-річчя від початку голоду актуалізус звернення до цієї теми та висвітлення раніше невідомих $\dddot{1 і}$ аспектів. Одним з таких аспектів $\epsilon$ подіï 1921-1923 рр. на території історичної Уманщини. Ця територія була неподалік кордону з голодуючими південними регіонами та достатньо добре відчувала масштаби голоду в сусідніх регіонах. До того ж, грабіжницька та насильницька політика більшовицького уряду зумовила катастрофічне становище жителів Уманщини також. 
Аналіз досліджень. В радянській Україні з'являлися історичні дослідження, у яких факт голоду 1921-1923 pр. не замовчувався, однак всіляко спотворювався. У 1923 р. в праці М. Гуревича «Голод и сельское хозяйство Украины» подано інформацію про голод на території України (Гуревич, 1923). Після цієї праці тема голоду знайшла відображення в дослідженнях А. Хоменка (Хоменко, 1927), В. Балієва, Г. Діденка (Діденко, 1962), Ю. Полякова (Поляков, 1975) та інших авторів. У період «перебудови» історики, публіцисти, літератори, громадські діячі звертали особливу увагу на дослідження радянських голодоморів, перш за все Голодомору 1932-1933 рр. З'явилися нові публікації про голод 1921-1923 рр. О. Мовчана (Мовчан, 1988), Є. Хенкіна (Хенкін, 1988) та ін., однак у цих працях не проаналізовано діяльність та прорахунки партійних і державних органів щодо недопущення та подолання голоду. 3 відновленням незалежності України історики отримали можливість вільно досліджувати раніше табуйовані теми радянського минулого, розпочалися процеси переходу від марксистсько-ленінських догм на нові методологічні засади. Значну роботу 3 вивчення голоду здійснює С. Кульчицький (Кульчицький, 1993), з-під чийого пера виходили i продовжують виходити цінні наукові дослідження голоду в Україні. У працях О. Мовчан (Мовчан, 2002) висвітлюються питання допомоги голодуючим та різні аспекти голоду.

Тема голоду 1921-1923 pp. розкрита в дисертаційних дослідженнях Б. Драмарецького, В. Силантьєва, В. Кириленка (Кириленко, 2015). Значний внесок у вивчення регіонального виміру голоду зробили історики-краєзнавці, в першу чергу південних регіонів України. Для написання своїх праць вони використовують масив документів 3 місцевих архівів, вивчають допомогу закордонних організацій голодуючим, аналізують регіональну за загальнодержавну пресу. У 1921-1923 рр. голод, щоправда в менших масштабах, був відчутний і у сусідніх з південними регіонами губерніях. Однак регіональний аспект означеного голоду на Уманщині не став предметом окремого дослідження.

Мета статті полягає у дослідженні відображення теми голоду 19211923 рр. на Уманщині у еgо-документах родини Курінних.

Виклад основного матеріалу. Важливим джерелом 3 вивчення історії Уманщини кінця XIX - перших десятиліть XX ст. є щоденник відомого громадського діяча, адвоката Петра Федоровича Курінного (1852 - 1931). На сторінках щоденника П. Ф. Курінний детально фіксував події, що відбувалися у його житті та навколо нього. Часто передав зміст розмов зі своїми знайомими, колегами та друзями, настрої суспільства 3 найактуальніших питань життя міста та країни. Йог осин, відомий український вчений, археолог, фундатор музейної справи Петро Петрович Курінний (1894-1972) до 1924 р. проживав в Умані, займався педагогічною та громадською діяльністю. Окрім цього П. П. Курінний листувався з відомими київськими вченими та музейниками у справі організації та діяльності уманського музею. У науковому архіві Інституту археології НАН України, в особистому архівному Петра Петровича Курінного зберігається значний масив еgо-документів його та його батька. У 
листуванні з рідними, знайомими, колегами відображено основні проблеми та побут мешканців України у 1920-1930-ті рр., зокрема і в голодні 19211923 роки.

У листі до Данила Щербаківського (1877 - 1927) П. П. Курінний, окрім вирішення власних справ інформує вченого про важке становище мешканців Уманщини, які у голодний рік опинилися без допомоги держави та задавлені непомірними податками. У листі від 21 серпня 1921 р. П. Курінний пише: «...живу так, аби дотягти до вечора, та вже часом почуваю на собі передумови недалекої «голодухи». Городи, хліба - вигоріли, а решта йде на голодаючих Сходу. Отже справді виходить мовляв по Свангельському - «самі себе й один одного Христу-Богу віддамо». Уявляю як Ви всі живете! Певне якась містерія шкелетів не більше, але й не менше...» (НА ІА НАНУ, ф. 9, спр. 168/к-468. Арк. 1.).

3 особистих документів, збережених у архіві П. П. Курінного чітко простежується, що голод 1921 р. був зумовлений не лише складними погодними умовами, але й деструктивною політикою радянської влади. Зокрема, чернетка заяви до сільської Продподаткової комісії Івангородського передмістя м. Умань, написана у 1922 р. П. П. Курінним свідчить про непомірні податки, що запроваджувалися новою владою. Згідно 3 цим документом, родина Курінних (складалася 35 сімейств (15 осіб) володіла 6 1/2 десятин польової землі. Попри те, що майже вся площа була засіяна (не вдалося засіяти та обробити $1 / 4$ десятин незручного для оброблення лужка), врожай був настільки малим, що зібраного зерна не вистачало ні для здачі продподатку, ні для забезпечення сім'ї хлібом до нового врожаю, ні для збереження посівного матеріалу для наступної посівної кампанії. Причини поганого врожаю П. П. Курінний виокремлював такі:

1. Відсутність у родини власного інвентаря та насіння, через що частина землі була здана спільнику Івану Тичинському та монахам.

2. 3 великої сім'ї лише 6 осіб могли працювати біля землі (батько П. Ф. Курінний та його дружина були занадто старі для праці, зять був призваний до Червоної Армії, діти (5 осіб) занадто малі для праці, сестра Поліна була на останніх місяцях вагітності. 3 тих 6 осіб, які могли працювати біля землі П. П. Курінний та його брат Дмитро Курінний були державними службовцями (працювали в I трудовій школі та уманській Райфілії відповідно) і більшість часу проводили на службі, тому не могли повноцінно обробляти землю.

П. П. Курінний звертався до сільської влади з проханням звільнити сім'ю від сплати продподатку, однак судячи зі ще однієї заяви від 16 березня 1922 р. стає зрозуміло, що задовольнити прохання сім'ї сільська рада відмовилася.

Окрім непомірних податків додавало селянам клопоту ще й те, що кожного року земельний наділ влада могла перенести на інше місце. 23 травня 1922 р. П. П. Курінний звертався до Повітової земельно-технічної комісії із заявою, в якій повідомляв, що з наявних у власності 6 десятин землі родина змогла знайти лише $13 / 4$ десятини в околицях села Паланки, а інша площа була кудись перенесена владою. Петро Петрович вимагав, аби сільська рада вказала 
де знаходиться інша частина земельного наділу, або ж дозволила обробляти увесь земельний наділ в старих межах (НА IA НАНУ, ф. 10, спр. К-54/11, арк. 7). У ще одній заяві від 1922 р. П. П. Курінний повідомляв сільську комісію Івангородського передмістя м. Умані, що із загальної земельної власності їхнього батька (6 десятин землі), які були розподілені між 4 сім'ями великої родини П. Ф. Курінного, знайдена і своєчасно оброблена лише одна ділянка землі (1 3/4 десятин). Попри розшуки серед сусідів та заяви до сількомісії, решту земельних площ не було наділено та відповідно не було засіяно. У зв'язку з цим родина інформувала сільську владу, що відмовляється на посівну кампанію 1922 року від 4 1⁄4 десятин «незнайденої» землі та просить не враховувати їі для оподаткування (НА ІА НАНУ, ф. 10, спр. К-54/11, арк. 6).

Аналізуючи щоденникові записи П. Ф. Курінного стає очевидним , що передумови початку голоду закладалися більшовицькою владою ще на початку посівної кампанії 1921 р. На початку березня 1921 р. загони червоноармійців в селі Подібна заборонили селянам розпочинати роботу в полі до того часу, допоки не отримають з села 70 возів податку. У відчаї селяни говорили, що більшовики заважають займатися господарством, однак вимагають хліба. «Мы так можем дожить до того, что и сами не будем иметь хлеба, - и они (большевики) будут голодны» - майже пророче говорили селяни на початку 1921 року (Торгало, 2014: 234). Сдине, що не збулося з цих слів - більшовики не залишилися без хліба, тому що вимітали його до останньої зернини 3 селянських засік. 26 березня 1921 р. більшовики скликали селян Подібної на збори та взяли 20 заручників до того часу, допоки селяни не виконають план здачі податків - 150 возів продовольства.

Такі заходи нової влади викликали обурення місцевого населення. Додавала невдоволення і кадрова політика більшовицької влади. Представники радянської влади на місцях (як правило комнезами) брали заручників, збирали податки, придумували абсурдні вказівки. Однак членами Комнезамів були зазвичай неосвічені та неавторитетні мешканці громади. Зокрема, Головою Волосного Комнезаму на Уманщині був Яків Печериця - колишній двірник П. Ф. Курінного. У селі Краснопілка ситуація була не кращою: «заправилами», тими, які старе знищували, а нове встановлювали - теж були не кращі люди сільської громади. Очолював радянську владу на селі чоловік, який був засуджений на два роки покарання волі за крадіжку. «Тепер хозяєва не мають голоса, а тільки якісь острожники!», - бідкалися селяни П. Ф. Курінному (Торгало, 2014:248).

Незважаючи на своє пролетарське та селянське походження, представники нової влади поводилися зверхньо. П. Ф. Курінний кінні екіпажі більшовицької влади порівнював 3 панськими, адже при зустрічі 3 ними пішоходи і перевізники були змушені розходитися по боках дороги для того, щоб більшовики проїхали без перешкод (Торгало, 2014: 235). Навіть під час похоронної процесії, коли жителі Івангородського передмістя супроводжували труну з покійником до монастиря, то зустрічний автомобіль більшовиків розігнав процесію. На початку травня 1921 р. в Умань приїхав член ЦК КП(б)У Володимир Затонський, якого місцеве населення називало «Начальником 
Правобережної України». Уманчан вразила розкішність, яка оточувала нового керівника: «вагон раскошный, убранство царское, чинопочитание, "строгость дисцыплины, возможные только при монархизме''...Словом, видно, что высшему начальству хорошо». Особливо контрастно це виглядало на фоні збіднілого населення (Торгало, 2014: 249).

Ще одна 3 проблем цього часу - постійне зростання цін та шалена інфляція. Якщо до війни П. Ф. Курінний купував бублик за $1 / 2$ копійки, то у 1921 р. його вартість складала 100 рублів. Радянські гроші неохоче приймали купці, а «керенські» були недійсними. Винними в цьому більшість населення вважали євреїв, які в основному займалися торгівлею і «то підвищували, то занижували» курс валюти з метою заробітку. У січні 1922 р. вартість чобіт на базарі коливалася від 200 тисяч до 2-х мільйонів рублів, але можливості їх купити у родини Курінних не було. Коштів не вистачало навіть для придбання на базарі найнеобхідніших продуктів харчування. У квітні 1922 р. на сторінках щоденника знову знаходимо відомості про шалену інфляцію на Уманщині. За тиждень вартість фунту сала зросла 3500000 рублів до 2-х мільйонів рублів. Радянські гроші неохоче приймали на місцевих базарах, більшість людей розраховувалися бартером: речі міняли на продукти чи зерно (Торгало, 2014: 301).

Радянська влада встановлювала великі розміри податків та жорстко контролювала процес вилучення продовольства у населення. У квітні $1921 \mathrm{p}$. біля околиць села Коржова П. Ф. Курінний став свідком того, як понад 100 возів з хлібом і стадо худоби супроводжували червоноармійці як «розверстку» 3 якогось села. Постійні реквізиції продовольства та худоби складали враження «беспощадного грабежа (Торгало, 2014: 239). Через кілька днів автор щоденника став свідком подібної картини, коли більшовики гнали багато худоби реквізованої в селі Колодистому. Окрім цього щоденно більшовики перевозили тони збіжжя, вилученого в селян як продрозверстка (Торгало, 2014: 244). У червні 1921 р. на родину П. Ф. Курінного було покладено зобов'язання здати 6 пудів зерна до сільської ради. На Івангородське передмістя Умані покладалася така розверстка: хліба 2104 пуди, картоплі 2275 пуд., худоба - 19 шт. (148 пуд.), свиней - 16 шт. (56 пуд.), овець - 62 шт., яєць - 32000 шт., масла - 35 ф. і щоденно молоко від корів. (Торгало, 2014: 253). Великі розміри податків призвели до того, що вже 3 липня 1921 р. серед уманчан були поширені розмови про те, що в селах люди залишилися без хліба. 15 серпня 1921 р. Комнезам Івангородського передмістя видав розпорядження про додатковий збір 1 пуду зерна 3 кожної десятини землі для допомоги голодуючим (Торгало, 2014: 259). Якщо в господарстві не було зерна, то 3 господарів вимагали свиту, чоботи чи інші дороговартісні речі. Окрім цього Комнезам проводив облік та фіксував скільки в господарстві фруктових дерев, скільки росте картоплі, капусти та іншої городини. В залежності від кількості посадженого встановлювався розмір натурального податку для кожного господарства. 3 фруктового дерева потрібно було сплатити 3 фунти вишень (в господарстві П. Ф. Курінного більшість фруктів червоноармійці обнесли 3 дерев ще до того, як вони дозріли) (Торгало, 2014: 259). У січні 1922 р. селяни 
Івангородського передмістя переймалися тим, як сплатити продподаток. Багато хто сидів без хліба і не мав чим сплатити податок, були ж і такі, що сплачували податок, однак потім самі залишалися без продовольства (Торгало, 2014: 280).

Окрім цього тягарем на селян падали і різноманітні контрибуції, які час від часу накладалися радянською владою. У квітні 1921 р. на селян с. Кочержинці було накладено контрибуцію 3 мільйони рублів на користь керівника сільської земельної комісії, який постраждав від пожежі (Торгало, 2014: 240). 20 березня 1922 р. у щоденнику зафіксовано, що влада розставила по дорогах і на базарі війська, які забирали з возів усі продукти, а особливо зерно у приїжджих. У травні 1922 р. додатковий податок для підтримки голодуючих було накладено на селян Соколівки.

Боротьбу з голодом, в першу чергу у поволзьких губерніях, радянська влада намагалася використати для антирелігійної боротьби. У травні 1922 р. священник з села Собківки розповідав П. Ф. Курінному, що спеціальна Комісія приїздила до церкви забрати на користь голодуючих церковні цінності, але зійшлися сільські жінки і не дали вилучити церковні речі. Комісія поїхала у сусіднє село Громи, де вилучила в церкві майно. 3 Охматівської церкви для підтримки голодуючих забрали чашу та інші цінності (Торгало, 2014: 315).

Ще одним елементом ленінської голодотворної політики в Україні було насадження в суспільстві атмосфери страху, доносів та репресій. Відповідно до рішення Ради праці і оборони про застосування надзвичайних заходів під час вилучення продподатку до сіл дозволялося вводити військові частини, які мали повноваження «негайно вживати найрішучіші заходи примусового характеру» для вилучення продовольства. На сторінках щоденника неодноразово зафіксовано, що місцеве населення намагалося уникнути зустрічі 3 більшовицькими військами. Люди передавали один одному інформацію про шляхи, якими пересувалися війська, аби оминути зустрічі з ними. «Какое скверное время! Все боятся войска, как дикой орды... Давно ли мы смотрели на солдат как на защитников, а теперь каждый 'товарищ' большевик наводит на каждого гражданина уныние, страх и ненависть»... (Торгало, 2014: 250). Ненависть до більшовицького війська була спричинена і неодноразовими грабунками населення. Для прикладу, 7 червня 1921 р. на село Ладижинку здійснив набіг кавалерійський загін більшовиків, які пограбували всіх на базарі, а потім базар розігнали (Торгало, 2014: 251). Через кілька днів подібні звістки лунали $з$ села Псярівка, 3 містечка Дубова та 3 інших населених пунктів Уманщини. У липні 1921 р. на с. Подібна напали кавалеристи 45 дивізії які окрім того, що здійснювали обшуки в населення та вилучали продовольство, кіньми їздили по людських городах то витолочували посаджену городину. Подібна атмосфера панувала всюди. Автор зазначав: «куда не посмотрю всюду большевики и шпионы, даже в поле...А в городе судят три «чрезвычайки» (Торгало, 2014: 240).

У жовтні 1921 р. на сторінках щоденника зафіксовано, що голод відчула родина Петра Федоровича Курінного. У цей час у них не було хліба, борошна, цукру. Замість чаю родина пила теплу воду. Щоб виправити ситуацію та заробити продукти для харчування Петро Федорович влаштувався працювати 
на млині в селі Соколівка, його син П. П. Курінний працював на кількох роботах в Умані (державних і ще додатково розвантажував вагони на вокзалі), то на Великодній стіл у 1922 р. родина зуміла дістати калач, шинку, яйця, сир і ковбасу. Хоча автор зазначив, що багато сімей не змогли накрити такого столу. Під час освячення продуктів біля церкви було багато голодуючих, які просили милостиню (Торгало, 2014: 294). У червні 1922 р. фіксував: «ничего у меня дома: ни завтракать, ни обедать... Кусочек хлеба и одна маленькая редиска». Такою ж ситуація була і в липні: «у нас теперь нет ни молока, ни хлеба, ни сала, ни муки» (Торгало, 2014: 321). Попри нестачу продуктів у населення найбільша ïх концентрація була на залізничному вокзалі. Навесні 1921 р. П. Ф. Курінний зафіксував у щоденнику, що червоноармійці пересилають масу вилученого продовольства у селах Уманщини потягом своїм рідним (Торгало, 2014: 239).

Спілкуючись 3 селянами П. Ф. Курінний фіксував їхні думки на сторінках щоденника. 72-річний житель с. Подібна розповідав Курінному: «розказували батьки, що за поміщика теж робили на панів і пряли мітки, але ж тоді хліба не збирали із селян i не знущались так, як тепер знущаються i ограбляють народ... .і казна требувала роботи (на 3 дні), але ж вона і помагала людям. То називалось '”панщина', а тепер воля» (Торгало, 2014: 266).

Напевно найсильніше голод родина Курінних відчувала взимку 1922 року. Саме в цей час П. Ф. Курінний часто записував на сторінках щоденника подібні думки: «Я вижу, что у меня дома настоящий голод... Вола сьел бы такой аппетит, есть хочется, а нечего... Безнадежность положения заставляет думать, что так жить трудно и невыносимо... Лучше умереть, но где же и как умирать, когда нет смерти? Страдать надо и жить надо, и тут старость ни при чем» (Торгало, 2014: 277).

На сторінках щоденника П. Ф. Курінний розмірковував про економічну політику більшовицької влади, яка спричинила важке становище населення Уманщини. Декларовані гасла зрівняння всіх у правах на практиці зводилися до того, що робітники, залишилися роботи і чекали подання, а інтелігенція, заради порятунки від голоду була змушена працювати на чорнових роботах. 3 колишніх працівників сформувався клас грабіжників, а 3 інтелігенції недосвідчені працівники фізичної праці. В результаті всі були відірвані від своєї звичної праці (Торгало, 2014: 277). В суспільстві панувала атмосфера недовіри до радянських газет і радянського уряду. Причиною цієї недовіри автор щоденника вважав те, що радянська влада не виконала жодної своєї обіцянки. Зокрема у народу все забрали, а натомість нічого йому не давали; в країні була цілковита розруха і не було надії на покращення життя; від голоду, хвороб і несправедливості постійно вмирали люди; безвинно і несправедливо було розстріляно «неисчислимое множество» громадян, багатьох утримували в тюрмах і підземеллях; влада брала хабарі і нечесно вела громадські та державні справи; був відсутній правовий суд. В податках і повинностях проявлялися свавілля, грабунки та знущання на людьми. Просвіта народу зупинена, школи закривалися, православна церква переслідувалася, робота підприємств не відновлена. Бентежило П. Курінного і те, що не було виборності влади, а нав'язані народу кандидати утримували владу через різноманітні репресивні 
заходи та фальсифікації під час виборів (Торгало, 2014: 301). Висловлені думки Петра Курінного свідчать про глибоке розуміння ним соціально-економічної та політичної ситуації в країні, причин голоду та змісту антинародної політики ленінської влади.

В місті відбувався збір допомоги для голодуючих. У січні 1922 р. на залізничній станції «Умань» повісився комуніст, який був відповідальний за збір коштів для підтримки голодуючих. Причиною самогубства було те, що він розтратив і крав гроші, а коли нестачі не вдалося замовчати - повісився. (Торгало, 2014: 278). 3 лютого 2022 р. на сторінках щоденника зафіксовано інформацію про голодуючих, які прибували до Уманщини 3 Поволжя, Катеринославської та інших голодуючих губерній. В деяких селах Уманщини вони грабували і вбивали людей. Багато випадків голодних смертей було зафіксовано на залізничній станції та у вагонах потягів. Там замерзали i вмирали обезсилені люди, які прибували до Умані з надією врятуватися від голодної смерті (Торгало, 2014: 285). У квітні 1922 р. П. Ф. Курінний був свідком того, як на місцевому кладовищі в одну могилу ховали десять дітей 3 дитячого будинку, які вмерли від голоду.

В голодні роки припинили свою роботу багато шкіл у селах Уманщини. Причиною цього було те, що селяни не мали можливості утримувати школу. «Нас ограбили, хліб забрали непомірними, страшними продналогами. У нас немає чого їсти, одягтись нема в що, де ж нам і звідки ми будемо держати школу? Нехай діти сидять дома, менше буде комуністів», - говорили П. Ф. Курінному жителі Соколівки (Торгало, 2014: 288).

Таким чином, проаналізувавши родинний архів Курінних можемо дійти висновку, що у еgо-документах Курінних зафіксовано відомості про перебіг голоду 1921-1923 рр. в Україні, зокрема на території Уманщини. 3 мемуарів та листів Курінних увиразнюється картина, що першопричиною голоду 19211923 pp. була посуха, ускладнена господарською розрухою села. Ця першопричина ускладнювалася політикою більшовицької влади, яка встановлювала надмірні розміри податків, накладала контрибуції та здійснювала відвертий грабіж селянства. Уманщина відчула голод 19211923 рр. не так катастрофічно, як південні губернії України, однак була задавлена великими податками. Досить часто селяни не мали чим сплатити податки, або ж після їх сплати залишалися без запасів продовольства.

\section{СПИСОК ВИКОРИСТАНИХ ДЖЕРЕЛ І ЛІТЕРАТУРИ}

Гуревич, 1923 - Гуревич М. Б. Голод и Сельское Хозяйство Украины. Очерк / Матвей Борисович Гуревич. Харьков: Первая Государственная Типография им. тов. Петровского Г.И., 1923. 47 с.

Диденко, 1962 - Диденко Г. Д. Рабочий класс Украины в годы восстановления народного хозяйства (19211925) / Григорий Демьянович Диденко. К.: Изд-во АН УССР, 1962. 375 с.

Кириленко, 2015 - Кириленко В. П. Голод 1921-1923 років у Південній Україні. Дис. ... канд. іст. наук. Міністерство освіти і науки України; Миколаївський національний університет ім. В. О. Сухомлинського. Миколаїв, 2015. 230 с.

Кульчицький, 1993 - Кульчицький С. В. Невідомі сторінки голоду 1921-1923 рр. в Україні / С. В. Кульчицький, О. М. Мовчан. К.: Ін-т історії України, 1993. 70 с.

Мовчан, 2002 - Мовчан О. М. Терор голодом в Україні в 1921-1923 роках / О. М. Мовчан // Проблеми історії України: факти, судження, пошуки. Київ: Інститут історії України НАН України, 2002. №7. С. 66-78. 
Мовчан, 1988 - Мовчан О. Н. Трудящиеся УССР в борьбе с продовольственным кризисом при переходе к нэпу / Ольга Николаевна Мовчан. К.: Наукова думка, 1988. 124 с.

НА ІА НАНУ - Науковий архів Інституту археології НАН України

Поляков, 1975 - Поляков Ю. А. 1921-й: победа над голодом / Юрий Александрович Поляков. М.: Политиздат, 1975. $112 \mathrm{c}$.

Торгало, 2014 - Умань і уманчани очима П. Ф. Курінного / Уклад. Ю. В. Торгало / Умань: Видавець «Сочінський», 2014. 428 с.

Хенкин, 1988 - Хенкин Е. М. Очерки истории борьбы Советского государства с голодом (1921-1922)/ Евель Моисеевич Хенкин. Красноярск: Изд-во Красноярского ун-та, 1988. 171 с.

Хоменко, 1927 - Хоменко А. П. Населення України (1897-1927 рр.) / Арсеній Петрович Хоменко. Харків: Державне видавництво України, 1927. 79 с.

\section{REFERENCES}

Gurevich, 1923 - Gurevich M. B. Golod i Selskoe Khoziaistvo Ukrainy. Ocherk [Famine and agriculture of Ukraine. Essay] / Matvei Borisovich Gurevich. Kharkov: Pervaia Gosudarstvennaia Tipografiia im. tov. Petrovskogo G. I., 1923. 47 s. [in Russian]

Didenko, 1962 - Didenko G. D. Rabochii klass Ukrainy v gody vosstanovleniia narodnogo khoziaistva (1921-1925) [Working class of Ukraine in the years of restoration of the national economy (1921-1925)] / Grigorii Demianovich Didenko. K.: Izd-vo AN USSR, 1962. 375 s. [in Russian]

Kyrylenko, 2015 - Kyrylenko V. P. Holod 1921-1923 rokiv u Pivdennii Ukraini [The famine of 1921-1923 in Southern Ukraine]. Dys. ... kand. ist. nauk. Ministerstvo osvity i nauky Ukrainy; Mykolaivskyi natsionalnyi universytet im. V. O. Sukhomlynskoho. Mykolaiv, 2015. 230 s. [in Ukrainian].

Kulchytskyi, 1993 - Kulchytskyi S. V. Nevidomi storinky holodu 1921-1923 rr. v Ukraini [Unknown pages of the famine of 1921-1923 in Ukraine] / S. V. Kulchytskyi, O. M. Movchan. K.: In-t istorii Ukrainy, 1993. 70 s. [in Ukrainian].

Movchan, 2002 - Movchan O. M. Teror holodom v Ukraini v 1921-1923 rokakh [The famine terror in Ukraine in 1921-1923] / O. M. Movchan // Problemy istorii Ukrainy: fakty, sudzhennia, poshuky. Kyiv: Instytut istorii Ukrainy NAN Ukrainy, 2002. №7. C. 66-78. [in Ukrainian].

Movchan, 1988 - Movchan O. N. Trudiashchiesia USSR v borbe s prodovolstvennym krizisom pri perekhode $\mathrm{k}$ nepu [Workers of the USSR in the fight against the food crisis in the transition to the nep] / Olga Nikolaevna Movchan. K.: Naukova dumka, 1988. 124 s. [in Russian]

NA IA NANU - Naukovyi arkhiv Instytutu arkheolohii NAN Ukrainy [Scientific archive of the Institute of Archeology of the National Academy of Sciences of Ukraine] [in Ukrainian].

Poliakov, 1975 - Poliakov Iu. A. 1921-i: pobeda nad golodom [1921: victory over hunger] / Iurii Aleksandrovich Poliakov. M.: Politizdat, 1975. 112 s. [in Russian]

Torhalo, 2014 - Uman i umanchany ochyma P. F. Kurinnoho [Uman and Uman residents through the eyes of P. F. Kurinnyi] / Uklad. Yu. V. Torhalo / Uman: Vydavets «Sochinskyi», 2014. 428 s. [in Ukrainian].

Khenkin, 1988 - Khenkin E. M. Ocherki istorii borby Sovetskogo gosudarstva s golodom (1921-1922) [Essays on the history of the struggle of the Soviet state against hunger (1921-1922)] / Evel Moiseevich Khenkin. Krasnoiarsk: Izd-vo Krasnoiarskogo un-ta, 1988. 171 s. [in Russian]

Khomenko, 1927 - Khomenko A. P. Naselennia Ukrainy (1897-1927 rr.) [Population of Ukraine 1897-1927] / Arsenii Petrovych Khomenko. Kharkiv: Derzhavne vydavnytstvo Ukrainy, 1927. 79 s. [in Ukrainian] 


\title{
ІСТОРІОГРАФІЯ, ДЖЕРЕЛОЗНАВСТВО ТА СПЕЦАЛЬНІ ІСТОРИЧНІ ДИСЦИПЛІНИ
}

УДК 323.17 (477)

\author{
Алла КИРИДОН \\ orcid.org/0000-0003-4375-5350 \\ доктор історичних наук, професор, \\ директор Державної наукової установи \\ «Енциклопедичне видавництво» \\ (м. Київ, Україна) \\ akyrydon@ukr.net
}

\section{ПАМ'ЯТТСВА ПАРАДИГМА ІДЕНТИЧНОСТІ: ЕКСПЛІКАЦІЯ СИСТЕМОТВОРЧИХ СЕГМЕНТІВ КОМЕМОРАТИВНИХ ПРАКТИК}

\begin{abstract}
Національна ідентичність, з одного боку, є однією з фундаментальних ідентичностей, тобто, вона може служити оріснтиром для людини навіть тоді, коли інші (професійні, родинні, класові) швидко змінюються внаслідок трансформації суспільства. 3 іншого боку, зміни суспільства, його соиіальних інститутів (як агентів впливу) змінюють зміст і форми національної ідентичності членів суспільства. Відтак усталення тієї чи іншої моделі ідентичності здійснюється в певному сочіальному контексті, який задає не тільки спектр альтернатив, але й набір різних комеморативних практик. У статті обгрунтовується взаємообумовленість смислоконституювання пам'яттєвого та ідентичнісного дискурсів, із урахуванням того, щчо пам'яттєвий дискурс, з одного боку, віддзеркалює характерні риси національної ідентичності, а з іншого формує своєрідну смислову основу останньої, моделює ї̈, впливаючи на зміни з різним ступенем інтенсивності. Доведено, щчо національна ідентичність формується за допомогою колективної пам'яті та комеморативних практик.
\end{abstract} практики.

Ключові слова: пам'ять, ідентичність, начіональна ідентичність, комеморачія, кмеморативні

Alla KYRDON,

Doctor of Historical Sciences, Professor, Director of the State Scientific Institution

«Encyclopedic Publishing House»

(Ukraine, Kyiv)

akyrydon@ukr.net

\section{MEMORIAL PARADIGM OF IDENTITY: EXPLANATION OF SYSTEM- FORMING SEGMENTS OF COMMEMORATIVE PRACTICES}

The article substantiates the interdependence of the meaning constitution of memory and identity discourses. Memorable discourse, on the one hand, reflects the characteristic features of national identity, and on the other -forms a peculiar semantic basis of the latter, modeling it, influencing changes with varying degrees of intensity. It is proven that national identity is formed through collective memory and commemorative practices.

The changes of socio-political contexts and axiological dominants inevitably determine the formation of corresponding social behavior matrices, the formation / transformation of the politics of memory with suitable parameters of the construction / reinterpretation of an image of the past. Therefore, the character of the formation of Ukrainian national identity is complicated, conflict-generating by its nature, painful by its emotional content, controversial. The expression of correlation of memory discourse with national identity in the conditions of unformed common value space requires taking into account time dynamics, pragmatic contextual interrelation between the past, present and future. Research relevance of mentioned problems stimulated the investigation of the interdependence of commemorations, identity and the clarification of a conceptual paradigm of the issue under consideration.

National identity is one of the fundamental identities. At the same time, changes in society and its social institutions (as agents of influence) change the content and forms of national identity of members of society. Therefore, 
the establishment of one or another model of identity is carried out in a particular social context that defines not only a range of alternatives but also a set of different commemorative practices.

Commemoration is based on collective memory and is a form of preservation and at the same time identity formation. Commemoration means a set of public collective practices aimed at shaping values and patterns of behavior through the ritualized holding and reproduction (repetition) of the current culture of meaningful representations of the past that are meaningful to the group. It is a common symbolic tribute to memory, a way to enhance and transmit memory of the past. The semantic range inherent in the interpretative framework of the phenomenon of commemoration is wide. We can talk about the formation of a kind of cognitive scenario of a homogeneous construct of the past, which is created within a certain large social group, has a clear focused message, is rooted in material and visual signs (memorial sites, monuments, plaques, etc.) and is fixed performative practices (worship ceremonies, anniversary celebrations, calendar, inventing traditions, etc.). In the broad sense of the word commemoration is all that connects a person with his past. In a narrow sense, the word commemoration is the perpetuation of the memory of events: the construction of monuments, the organization of museums, the definition of significant dates, holidays, mass events, renaming of streets, creating new traditions and more. Commemorations bring to light collective memory, ethical and political endeavors, dominant ideologies and more. Commemoration centers around three interrelated aspects:

- material,

- symbolic

- functional.

Keywords: memory, identity, national identity, commemoration, memorial practices.

Постановка проблеми. Зміни суспільно-політичних контекстів та аксіологічних домінант неминуче детермінують формування відповідних матриць соціальної поведінки, вироблення / трансформацію політики пам'яті 3 відповідними параметрами конструювання / реінтерпретації образу минулого. Відтак конституювання національної ідентичності в Україні має складний, конфліктогенний за природою, болючий за емоційним наповненням, суперечливий за змістом характер. Увиразнення кореляції пам'яттєвого дискурсу 3 національною ідентичністю в умовах несформованого спільного ціннісного простору потребує врахування часової динаміки й прагматичної контекстуальної зчепленості минулого, теперішнього й майбутнього. Актуальність окреслених проблем стимулювала осмислення взаємозалежності комеморацій та ідентичності та уточнення концептуальної парадигми проблеми.

Мета статті. Концептуалізація теоретико-методологічного підгрунтя для увиразнення взаємозалежності пам'яттєвої складової та національної ідентичності. Для цього вдамося до експлікації взаємопов'язаних понять, які детермінують одне одного, певним чином співвіднесені або синхронізовані в царині національно-культурної ідентичності та пам'яттєвих смислів (національна ідентичність, комеморації, політика пам'яті тощо).

Гіпотеза дослідження вилоновується на взаємообумовленості смислоконституювання пам'яттєвого та ідентичнісного дискурсів, із урахуванням того, що пам'яттєвий дискурс, 3 одного боку, віддзеркалює характерні риси національної ідентичності, а з іншого - формує своєрідну смислову основу останньої, моделює їі, впливаючи на зміни з різним ступенем інтенсивності (національна ідентичність формується за допомогою колективної пам'яті та комеморативних практик). Форми соціокультурної самоідентифікації не залишаються однаковими, а історично змінюються. Національна ідентичність, з одного боку, є однією з фундаментальних ідентичностей, тобто, вона може служити орієнтиром для людини навіть тоді, коли інші (професійні, родинні, класові) швидко змінюються внаслідок трансформації суспільства. 3 
іншого боку, зміни суспільства, його соціальних інститутів (як агентів впливу) змінюють зміст і форми національної ідентичності членів суспільства (Гузьман, Саппа, 2016: 66). Відтак усталення тієї чи іншої моделі ідентичності здійснюється в певному соціальному контексті, який задає не тільки спектр альтернатив, але й набір різних комеморативних практик.

3 огляду на те, що гіпотеза є способом пізнавальної діяльності й побудови ймовірного знання, коли «формулюється одна 3 можливих відповідей на питання, що виникло під час дослідження» (Філософський словник, 2002: 121), ми свідомі відкритості й багатоаспектності сюжетів порушеної проблеми.

Аналіз досліджень. Окремі аспекти національної ідентичності та пам'яттєвого дискурсу увиразнилися в наукових рефлексіях зарубіжних дослідників (М. Альбвакс, Б. Андерсон, А. Ассман, 3. Бауман, Р. Брубейкер, А. Васільєв， С. Гантінгтон，О. Гнатюк， Е. Гобсбаум， Е. Гелнер， М. Гібернау, Л. Грінфелд, О.Г. Ексле, Елі Дж.(Geoff Eley), А. Еткінд, Ю. Зарецький Ф. Йейтс, К. Касторіадіс, Р. Козеллек, П. Коннертон, Н. Копосов, Д. Лангевіше, Ле Гофф Ж., М. Маколі, О. Малінова, А. Мегілл, П. Нора, А. Полєтаєв, Е. Ренан, Т. Ренджер, Л. Рєпіна, П. Рікер, Є. Романовська, М. Румянцева, Й. Рюзен, І. Савельєва, Е. Сміт, А. Смоляр, Ж. Тощенко, П. Хаттон, Б. Шацька, В. Шнірельман, П. Штомпка, Б. Як та ін.). Серед українських дослідників проблематику комеморації та національної ідентичності розглядали I. Васірук, Ю. Зерній, Г. Касьянов, А Киридон, М. Козловець, А. Коник, Н. Кривда, О. Крупка, Л. Нагорна, В. Пержун, Ю. Сорока, М. Степико, Н. Тарасова, О. Удод та ін.

Виклад основного матеріалу. Досліднищька стратегія полягала в потребі вивчення атрибутивних ознак, сутнісних характеристик та механізмів комеморативних практик, задіяних у конструюванні процесів національної ідентифікації; увиразнення інтерпретаційного потенціалу комеморативного інструментарію, який впливає на досяжність національної ідентичності й колективної пам'яті чи навпаки, створення прецеденту конфлікту пам'яті нової зі старою, війн між пам'яттю різних етнічних і вікових верств суспільства тощо (Тарасова, 2017: 142).

Відтак концептуальна схема заявленого дискурсу передбачає експозицію кількох проблемних полів і відповідні наукові рефлексії щодо системотворчих взаємоконституйованих сегментів: ідентичність / національна ідентичність, комеморації, комеморативні практики, пам'ять, колективна / соціальна пам'ять, політика пам'яті, пам'ять і забуття тощо.

Теоретична рамка підходу вибудовувалася на ідеях соціальних рамок пам'яті М. Альбвакса (Хальбвакс, 2007), пам'яті й забуття в уявлених спільнотах Б. Андерсона (Андерсон, 2001), простору спогаду А. Ассман (Ассман, 2012), формуванні пам’яті суспільств П. Коннертона (Коннертон, 2004), оприявнення минулого Р. Козеллека (Козеллек, 2005; Козеллек, 2006), місць пам'яті П. Нора (Нора, 1998; Нора та ін., 1999; Нора, 2005; Nora, 1994), обумовленості пам'ятання й забування П. Рікера (Рикёр, 2004), концепції комеморативної політики в національній ідентифікації Р. Брубейкера (Брюбейкер, 2012; Брюбейкер, 2006), ідеї про схеми спадкоємності в контексті 
теорії соціально-темпорального розуміння суспільства К. Касторіадіса (Касториадис, 2003) та ін. Базовим є положення Е. Дюркгейма: суспільство потребує певної міри не тільки інтелектуального і емоційного конформізму своїх членів, а й конформізму меморіального (Дюркгейм, 1998: 174-231). Іншими словами, члени групи в ході ритуалізованої діяльності повинні дотримуватись визначеної об'єднуючої комеморативної програми, сфокусованої на консолідації групи / суспільства.

Аналітична модель угрунтована на розумінні того, що смислова багатозначність культурно-історичних мнемонічних об'єктів потенційно містить можливість множинних інтерпретацій унаслідок наявних ознак часової й просторової змінюваності змісту, зумовленості його соціальними й культурними взаємодіями, певними інтерпретаційними ангажементами (Брюбейкер, 2012: 290-291). Стан та характеристики спільноти задають відповідні рамки комеморацій.

Покрокова реалізація досягнення задекларованої мети передусім потребує окреслення сутнісних характеристик понять.

Національна ідентичність. Поняття «національна ідентичність» означає широкий комплекс індивідуалізованих і неіндивідуалізованих міжособистісних зв'язків та історичних уявлень, який становить основу самоідентифікації окремих осіб та груп людей з певною нацією як самобутною спільнотою, що має свою історичну територію, мову, історичну пам'ять, культуру, міфи, традиції, об'єкти поклоніння, національну ідею (Нагорна, 2005). Поняття національної ідентичності належить до розряду соціально-політичних, які зорієнтовані на вироблення еталонів етносоціальної, політичної поведінки. Національна ідентичність спирається на культурні й громадсько-політичні традиції, інтереси, перспективи політичного розвитку, спільні політичні інститути, права та обов'язки, економічний і соціальний простір, спільність громадянства. Цілісність національної ідентичності сприяє збереженню консенсусу з фундаментальних питань розвитку держави (Гузьман, Саппа, 2016: 66).

Відомий англійський дослідник національної проблематики Е. Сміт у праці «Національна ідентичність» виокремлює п'ять головних елементів національної ідентичності: перший - історична територія, або рідний край; другий - спільні міфи та історична пам'ять; третій - спільна масова, громадська культура; четвертий - єдині юридичні права та обов'язки для всіх членів; п'ятий - спільна економіка 3 можливістю пересуватися у межах національної території. Наведені вище позиції дають підстави стверджувати, що національна ідентичність $\epsilon$ ширшим явищем, аніж певний акт самоусвідомлення. Вона передбачає ототожнення індивіда зі спільнотою самим способом його існування. Відтак, національна ідентичність є передусім онтологічним феноменом (Сміт, 1994: 23).

Національна ідентичність утворюється і обумовлюється низкою компонентів (територіальним, етнічним, культурним, релігійним, політичним, правовим, економічним). Усі компоненти $\epsilon$ взаємопов'язаними та взаємозалежними, хоча кожна історична доба виявляє домінантну роль якогось 
iз них або комбінації компонентів, які залежать не тільки від певних історичних обставин, але й від способу творення нації. Кожне історичне суспільство розвивається на власних підставах і у властивих для нього темпоритмах, які не збігаються з засадами і ритмами інших спільнот.

Загальнонаціональна ідентичність - ототожнення себе людиною з певною спільнотою, іiі символами, цінностями, історією, територією, культурою, державними та правовими інституціями, політичними й економічними інтересами - $\epsilon$ консолідуючою засадою будь-якого суспільства, у тому числі й України. Причому йдеться про прийняття цієї ідентичності не лише на суто раціональному рівні, а й на емоційному, семантико-міфологічному (Нечитайло, 2014: 338; Степико, 2011: 171-172; Україна, 2007: 19).

Дослідники Л. Нагорна (Нагорна, 2011), О. Пташник-Сердюк (ПташникСердюк, 2012), М. Степико (Степико, 2011) підкреслюють необхідність розмежовувати поняття ідентичності як певного стану й ідентифікації як процесу, що веде до цього стану. Ідентичність $\epsilon$ соціальною за своїм походженням, формується у взаємодії з іншими людьми й у діяльності на основі ідентифікації з цінностями, що наявні в суспільстві; іiі зміни зумовлені насамперед соціальними змінами. Зміст ідентичності утворюється двома важливими аспектами: особистісним i соціальним, які відображають усвідомлення людиною власної автономності, унікальності, разом із відчуттям належності до соціальної групи. Ідентичність - це динамічна структура, яка розвивається упродовж всього людського життя, причому цей розвиток $\epsilon$ нелінійним та нерівномірним, він проходить через подолання криз ідентичності, може йти як у прогресивному, так і у регресивному напрямі.

Ідентифікація $є$ низкою кроків на шляху до формування ідентичності; йдеться про процес набуття особистістю ознак ідентичності. Відповідно, ідентифікація розглядається як процес, включений в цілісну життєдіяльність суб'єкта, нерозривно пов'язаний 3 когнітивною, емоційною, ціннісносмисловою та поведінковою сферами особистості, зумовлений іiі потребами, мотивами, цілями i установками, опосередкований мовою, нормативнозвичаєвими, знаково-символічними, ідейно-образними та ціннісно-смисловими системами культури (Воропаєва, 2011).

Б. Андерсон вказував на сконструйованість націй - «уявлені спільноти»: нації уявлялися за допомогою конкретних культурних практик, міфів, символів, які сприяють консолідації спільноти (Андерсон, 2001). При цьому, як зауважував Ю. Лотман, символ може виступати механізмом колективної пам'яті (Лотман, 1992). Символічний спосіб фіксації знання лежить в основі будь-якого семіотичного коду. Очевидно, що кожна нація та будь-яка національна держава мають визначити для себе (свідомо чи несвідомо), за допомогою яких символів вони б хотіли презентувати себе на індивідуальному чи колективному рівні. Усі успішні нації володіють набором стрижневих символічних елементів, що $є$ для їх громадян своєрідними «критеріями істини» (Степико, 2011: 172).

Становлення національної ідентичності $\epsilon$ результатом взаємодії ідентифікаційних чинників - етнічного, мовно-культурного, релігійного, 
регіонального, геополітичного, державно-політичного тощо. Одним зі складників формування та оприсутнення національної ідентичності $€$ пам'яттєвий дискурс.

Колективна пам'ять на суспільному рівні сприяє груповій ідентичності трояким чином.

1. По-перше, як усвідомлення спільного минулого, тобто спільного тривання в часі, що породжує емоційний відгук серед членів спільноти, якою б вона не була.

2. По-друге, як переказ вартостей і зразків поведінки.

3. По-третє, в колективній пам'яті постаті та події минулих часів перетворюються на сукупність символів, які творять особливу, притаманну групі «мову». Завдяки цим символам колективна пам'ять переказує ідентифікаційні знаки, які допомагають відрізняти своїх від чужих (Шацька, 2011: 30-31).

Отже, колективна пам'ять безпосередньо пов'язана 3 ідентичністю 3 огляду на те, що вона є вираженням «колективного досвіду, що об'єднує групу, роз'яснює їй сенс ії минулого, причини нинішнього спільного буття і визначає надії на майбутнє» (Васильев, 2009: 60). При цьому колективна пам'ять $€$ універсальним транслятором смислів, цінностей і символів від покоління до покоління, що об'єднуює в єдине цілісне утворення, яке зветься нацією (Смолина, 2015: 120). Отже, колективна пам'ять забезпечує тяглість поколінь, що оприявнюється в колективній ідентичності, яка навантажена цінностями, змістом, відносинами.

У зв'язку з останнім в контексті осягнення комеморативних практик у формуванні / конструюванні ідентичності, необхідно відзначити i такий феномен, як «соціальне забуття» (втрату тих чи інших відомостей про минуле, образів минулого в культурі). Соціальне забуття може носити як природний характер, так і стати наслідком особливої політики забуття - свого роду тіні політики увічнення, яка супроводжує їй за принципом навпаки і складається в цілеспрямованому «викреслення» тих чи інших явищ 3 колективної пам'яті даної культури. Соціальне забуття цілком природне явище, хоча часом отримує однозначно позитивну (допомагає уникнути перевантаження), або навпаки, однозначно негативну (прагнення приховати правду) оцінку в працях соціологів та істориків.

Польська соціологиня Б. Шацька пише про способи «переінакшення» пам'яті спільнотами:

1) оминання (Вибіркове замовчування деяких неприємних фактів);

2) фальшування (Доповненням до заперечення чогось, що сталося, $\epsilon$ твердження, буцім трапилося те, чого ніколи не було);

3) перебільшення та прикрашання (Цілковите фабрикування фальшивої групової пам'яті - дуже складна річ, і трапляється рідко. Натомість, відносно легким і частим є роздування певних фрагментів історичної правди до розмірів великого, важливого для групи міту і представлення дрібних осягень як вікопомних тріумфів);

4) пов'язування versus відривання, або ж маніпулювання зв'язками 
(Кожна подія має зазвичай багато причин. Концентруючи увагу на одних із них i замовчуюючи інші, можна не заперечувати фактів, проте упереджено їх інтерпретувати);

5) звинувачення ворогів (Підкреслювання та вирізнення справжніх i надуманих провин і безчесності ворогів і неприятелів (інших, чужих) задля мінімізації власних провин, які представляють реакцію на поведінку ворога. Граничною формою цього переінакшення є приписування ворогові власного безчестя);

6) перекладання вини на обставини (Якщо для мінімізації власних провин не вдасться перекласти провину на ворогів чи на свої жертви, можна звинуватити ще обставини);

7) конструювання контексту (Історичні події перебувають у заплутаній мережі пов'язаних між собою зумовлень, причин та наслідків Колективна пам'ять редукує їх і зводить до простих пояснень. Вона вибірково вирізняє той чи інший збіг обставин і розміщує події в такому контексті, щоб їх образ сприяв позитивному образові групи) (Шацька, 2011: 30-31).

На думку британського дослідника лібералізму й націоналізму К. Майноута, мета національної ідентифікації полягає в комеморативному поверненні у свідомість національної спільноти пам'яті минулого, що завжди виступає у функції смислового виправдання сьогодення: «Спонукальна сила націоналістичної теорії полягає в тому, щоб відкрити минуле, яке підтримає поривання сьогодення» (Майноут, 2000: 255-256). Будь-яке суспільство, дбаючи про свою цілісність, виробляє систему соціальних кодів (програм) поведінки, що пропонуються його членам. Так, після розпаду СРСР всі колишні союзні республіки постали перед необхідністю формування смислових рамок нових ідентичностей на основі існуючих символічних ресурсів.

3-поміж інструментів конструювання колективної ідентичності увиразнюються комеморації.

Комеморація угрунтовується на колективній пам'яті та є однією з форм збереження й водночас формування ідентичності. Термін «комеморація» впроваджений в обіг французькими істориками, які обгрунтовували його в контексті важливості вивчення матеріального компонента колективної пам'яті. Концепція комеморації поширилася в 80-ті роки XX століття зарубіжними соціологами як категорії раціоналізації способів установлення зв'язку 3 минулим інструментарієм суспільно значимих видів діяльності. Під комеморацією розуміють сукупність публічних колективних практик, спрямованих на формування цінностей і моделей поведінки через ритуально оформлене утримання і відтворення (повторення) в актуальній культурі значущих для групи, символічно виражених уявлень про минуле. Йдеться про спільне символічне вшанування пам'яті, спосіб, за допомогою якого зміцнюється i передається пам'ять про минуле. Комеморація допомагає усвідомленню каузальності проведення комеморативних політик і результатів протікання процесів національної ідентифікації (Тарасова, 2017: 140).

Широким $\epsilon$ смисловий діапазон, притаманний для інтерпретативних рамок феномена комемораціі: від інструменту підтримки колективної 
солідарності та трансляції культурної пам'яті до конкретно-діяльнісних форм втілення цієї пам'яті. Можна говорити про формування своєрідного когнітивного сценарію щодо однорідного конструкта минулого, який створюється в рамках певної великої соціальної групи, має чіткий фокусований посил, вкорінюється в матеріальних і візуальних знаках (меморіальні місця,і пам'ятники, пам'ятні дошки тощо) i закріплюється через перформативні практики (церемонії вшановування, відзначення річниць, календар, винайдення традицій тощо). Комеморація $\epsilon$ сукупністю суспільних актів «згадування» $\mathrm{i}$ (пере)осмислення історичних подій, інституцій, персон в сучасному контексті (Малинова, 2017: 10). Проблема вшанування пам'яті пов'язана зі сприйманням суспільством свого минулого, закарбовуванням у суспільній свідомості певних епізодів минулого. У комемораціях оприявнюються колективна пам'ять, етичні й політичні починання, панівні ідеології тощо.

У вузькому сенсі слова комеморації - це увічнення пам'яті про події: спорудження пам'ятників, організація музеїв, визначення знаменних дат, свят, масові заходи, перейменування вулиць, творення нових традицій тощо. Це можуть бути і різні артефакти, і ідеї, і тексти - те, що позиціонується як меморіальна діяльність. Рекомеморація - цілеспрямований процес забуття імен, дат, фактів історії тощо. У широкому сенсі слова комеморації - це все, що пов'язує людину 3 iii минулим. За функціональної схожості пам'яті й комеморацій, між ними є відмінності, увиразнені А. Мегіллом: якщо пам'ять $\epsilon$ «побічним продуктом минулого досвіду», то комеморація виникає в сьогоденні 3 бажання конкретної спільноти констатувати почуття своєї єдності й спільності, зміцнюючи зв'язки всередині спільноти через спільно поділюване його членами ставлення до минулих подій чи їх репрезентації. Якщо пам ять по суті - це взаємодія між повторенням і запам'ятовуванням, то комеморація і $є$ цим свідомим повторенням (Мегилл, 2007: 116).

Назагал комеморації центруються в трьох взаємопов'язаних аспектах:

- матеріальному,

- символічному

-

Значущими ознаками комемораціі є іï колективний характер, публічність (репрезентує інтереси групи) i інституційність (цілеспрямована організованість). Характерною рисою $\epsilon$ апелювання не стільки до раціонального, знаннєвого, скільки до емоційно-чуттєвих начал людської особистості. Відтак важливою рисою комеморації є емоційна заангажованість іiі учасників до меморіального дійства. Комеморативна комунікація здійснюється не стільки в просторі даних і фактів, скільки в просторі образів, символів і архитепічних уявлень. Комемораціі слугують засобом не тільки трансляції, але й форматування колективної пам'яті. В актах поклоніння пам'ять стає комеморацією.

Різні відносини та інтереси трансформуються в меморіальні форми завдяки ініціативі певних осіб. Меморіальні об'єкти не створюються самі по собі - їх породжують і створюють ті, хто хотів би запровадити в суспільну свідомість певні події і людей, про яких всі інші радше схильні забути. Таке 
уявлення про появу меморіальних об'єктів передбачає, що в процесі їх спорудження конкуруючі «ідейні натхненники» шукають громадські майданчики і громадську підтримку для своєї інтерпретації минулого. Саме такі інтерпретації втілюються в символічній структурі меморіальних об'єктів (Вагнер-Пацифи, Шварц, 2011: 160). Перш ніж та чи інша подія підлягатиме увічненню, перш ніж будь-яка група осіб буде визнана учасниками цієї події, повинні 3'явитися окремі репрезентанти (особи, групи людей та ін.), які означують / маркують і саму подію, i його учасників пам'ятним явищем і здатні переконати в цьому інших. Водночас комеморація - це процес відбору того, що належить згадувати, а що піддавати забуттю. «Пригадується» те, що здається важливим із позицій сьогодення. «Забувається» те, що видається «деталями» або «випадковостями». Логіка «згадування» і «забуття» враховує не тільки «правду» історичних фактів, а й пов'язані з ними емоції. Залежно від контексту «згадувана» подія може розглядатися як привід для урочистостей i / або колективної скорботи. При цьому установки мнемонічних акторів на цей рахунок можуть не збігатися (Малинова, 2018: 13).

Феномен комемораціі (як свідомого увічнення) уявляється сукупністю соціокультурних мнемічних практик, що породжують комеморативні знаки / символи. Вибір комеморативних методів і засобів узалежнений від стану розвитку соціуму та політики пам'яті з відповідним усталенням символікомнемонічних кодів доби (вшанування героїв, відзначення / забуття подій, увиразнення топографічних об'єктів тощо). Комемораційні методи $\epsilon$ обов'язковим інструментарієм до застосування на етапі «збудження», прагнення стати нацією.

У процесах національної ідентифікації засобом духовного перетворення «старої» свідомості на «нову», ототожнення 3 героїчним минулим стають комеморативні практики. Комеморативні практики це:

- спосіб репрезентації минулого,

- особливий вид соціокультурної діяльності, в основі якої лежить акт увічнення як спроба збереження образу себе, своїх ближніх, своєї культури в теперішньому і в майбутньому;

- один із найпоширеніших засобів конструювання колективної / соціальної пам'яті та ідентичності.

Постання системисмислових $\mathrm{i}$ ціннісних домінант комеморативних практик центрується довкола взаємозалежної синергетики означування, осмислювання та осенсовування розвитку соціуму, політики пам'яті конкретного періоду та засад формування національної ідентичності. Вибір комеморативних практик завжди залежать від соціокультурних (зокрема політичних) імперативів, а також від конкретної зацікавленості суб'єктів історичної пам'яті, створюючи прецеденти перегляду іï ціннісного наповнення (Стасевська, 2018: 123-135). Комеморативні практики стимулюють особисте національне самовизначення, вони заміщують відчуття національної меншовартості відчуттям національної самодостатності (Тарасова, 2017: 140143).

Комеморації реалізуються у відповідно маркованому й структурованому 
культурному просторі. Показовим є вироблення в суспільстві меморіальної культури (культури увічнення, комеморативної культури), яка відповідає за процес формування образів в культурі сьогодення для подальшої трансляції в майбутнє. П. Нора розглядає сучасну меморіальну культуру як сукупність місць пам'яті, в яких сконцентрована комеморація. На думку вченого, колективна пам'ять будь-якої соціальної групи концентрується в певних місцях - місцях пам'яті (фр. lieu de mémoire). Поняття «місце пам'яті» використовується П. Нора на позначення символічних об'єктів, 3 якими певна група людей пов'язує свої спогади та цінності й де «пам'ять кристалізується і знаходить свій притулок» (Нора, 2005). До місць пам'яті віднесено найрізноманітніші культурно-історичні явища й феномени: географічні та архітектурні об'єкти, будівлі, предмети, літературні твори, книги, рукописи, кінофільми, пісні, історичні події, окремі люди й цілі покоління (Нора, 1998).

Іноді терміни меморіальна культура і комеморативна культура (культура комемораціi) постають синонімічно (за усталеністю в англомовній науковій традиції). Принагідно зауважимо побутування загальнішого терміну «культура пам'яті» (охоплює також явища, не пов'язані 3 безпосередніми акціями свідомого увічнення; окрім того, до культури пам'яті входить і соціальне забуття).

Відтак, комеморації є свідомим соціальним актом передачі морально, естетично, світоглядно або технологічно значимої інформації чи іiі актуалізації шляхом увічнення певних подій та осіб, тобто введення образів минулого в пласт сучасної культури. При цьому актуалізація пам'яті про історичні події та постаті, - це завжди політичний процес (Малинова, 2018), який унаочнюється посередництвом політики пам'яті.

Політика пам'яті - це селективна сукупність офіційних репрезентацій різних рівнів смислових образів / меседжів, пов'язаних 3 минулим, 3 метою створення / консолідації, іміджевої характеристики групи/нації та окреслення простору «свій-чужий» («чужий / інший»). Отже, політика пам'яті конструює / задає модель та ціннісно-нормативні засади ідентифікації.

Політика пам'яті, як механізм трансляції й актуалізації національних смислів, формує своєрідні соціально-культурні матриці для визначення національної ідентичності, норми консолідації та ідентифікації, норми відповідності соціальним цінностям та культурним зразкам задля визрівання цілісної національної ідентичності, яка об'єднувала б більшість громадян України. Саме на цьому грунтується їхня особлива політико-ідеологічна значимість та маніпулятивний потенціал. При цьому варто зважити на твердження М. Гібернау: «Люди, які заявляють, що поділяють якусь конкретну національну ідентичність, 3 різною силою покликаються на віру в спільну культуру, історію, спорідненість, мову, релігію, територію і долю». Відбувається своєрідне переструктурування минулого: політично домінуючі групи маніпулюють образами минулого і навіюють масам певну концепцію історії, що легітимує їхню політичну мету й панування, нові традиції й ритуали довільно конструюються у відповідності до поточних політичних реалій та потреб (Гібернау, 2012). Суперечливість, а часом і взаємозаперечення 
соціально-культурних матриць для визначення національної, етнічної, релігійної, групової ідентичності стають полем маніпуляцій і спекуляцій (Коник, 2009). Звідси політика пам'яті засадничо не передбачає свободи, вибудовуючи своєрідний замкнений смисловий універсум, обмежена наслідуванням певним «священним» взірцям у межах встановленого нею коду.

Політика пам'яті виявляє здатність конденсувати/трансформувати інформацію, актуалізуючи та розширюючи одні аспекти та тимчасово чи повністю витісняючи/нівелюючи інші. Тобто - виконує функцію комуніканта між суспільством і державою, тим самим стає чимось на зразок колективної культурної пам'яті. Культуротворче навантаження останньої також впливає на ідентифікаційні процеси. Конструювання/форматування національної ідентичності відбувається посередництвом активізації колективної пам'яті та колективних уявлень. Будь-який соціум, володіючи певною сумою знань про минуле, зацікавлений у структуризації й кодифікації відповідного теоретичного й емпіричного знання. Не меншою мірою його турбують проблеми запам'ятовування, пригадування, забування як відображення здатності до цивілізованого співжиття. Адже, згідно з твердженням Н. Лумана, ідентичності конденсують і засвідчують соціальну пам'ять системи: «Вони визначають, що можна піддати забуттю, а що згадати, тобто встановлюють, що 3 минулого залишається в сьогоденні; i тим самим вони водночас керують простором осциляції майбутньому, тобто формами, в яких очікування...справджуються або призводить до розчарування».

Зміни суспільно-політичної дійсності неминуче призводять до вироблення/трансформації політики пам'яті 3 відповідними параметрами конструювання образу минулого. 3 огляду на постійну «зміну минулого в сучасних дискурсах» (М. Фуко), можна стверджувати: те, що пам'ятають про минуле, залежить від способу його репрезентації, від спроможності соціальних груп витворити образ минулого (при цьому акцентується та актуалізується здебільшого героїчне минуле, як «скрепи нації»).

Політика пам'яті на суспільному рівні сприяє груповій / національній ідентичності принаймні трояким чином.

По-перше, формування моделей пам'яттєвого дискурсу й трансляція вартостей спільноти. Політика пам'яті $\epsilon$ тим символічним ресурсом, який використовується для виховання патріотизму, національно-громадянської ідентичності й толерантності

По-друге, сфокусованість на усвідомленні спільного минулого (тобто спільного тривання в часі) має породжувати емоційний відгук серед членів спільноти. Серед заходів - влаштування розмаїтих ювілеїв, святкування річниць пам'ятних дат, найрізноманітніших інституцій, організацій тощо.

По-третє, інструменталізація політики пам'яті формує символічний універсум, який окреслює своєрідні символічні кордони спільноти за допомогою маркерів, що «випромінюють» смисли, норми й емоції. Завдяки цим символам колективна пам'ять переказує ідентифікаційні знаки, які допомагають відрізняти своїх від чужих.

Комеморативна діяльність - особливий вид соціокультурної діяльності, в 
основі якої лежить акт увічнення як спроба збереження образу себе, своїх ближніх, своєї культури в сьогоденні і в майбутньому Культура увічнення включає в себе соціокультурні практики, спрямовані на свідоме формування й транслювання в майбутнє певної інформації як про свою епоху, так і про іiі ставлення до попередньої історії. Комеморації слугують своєрідним індикатором взаємин влади (офіційна політика пам'яті) і мас (колективною пам'яттю соціальних груп масовою або груповою свідомістю. Умови та чинники динаміки комеморацій узалежнені від фонової суспільно-політичної ситуації й відповідної політики пам'яті доби, культурно-інтелектуального фону епохи, освітньої політики періоду, зовнішньополітичного контексту тощо.

Важливим структуротворчим компонентом комеморацій, як $\mathrm{i}$ національної ідентичності, є коди та символи. Символіка виконує специфічну (засновану не на раціональному, а на емоційному грунті) комунікативну функцію, спрямовану на інтегрування й консолідацію спільноти, а відтак вилоновування національної ідентичності. Значення символу полягає в тому, що він слугує орієнтиром, «програмою», «інструкцією» для поведінки та взаємовідносин учасників символічних актів (Зиновьев, 2008: 11). Вибудуваний символічний ландшафт соціуму слугує не просто фоном; він $є$ способом i місцем онтологічного укорінення людської істоти, іï самоідентифіації щодо царини смислів і тезаурусу смислів культури. За видовою характеристикою російський дослідник А. Коноваленко пропонує таку класифікацію (Коноваленко, 2005: 36).

символ-ідея (здебільшого це все те, що зазвичай виражає ідеологію: політичні програми, платформи, статути, лозунги, девізи, репліки політичних лідерів тощо); до цього ж виду належать загальні ідеї, що символізують національну ідентичність (наприклад, особливий шлях держави; національний характер тощо);

символ-дія (мітинги, партійні збори, з'їзди, спортивні заходи, народні гуляння і свята - ці символи виконують об'єднуючу функцію; дія набуває статусу символічного, якщо вона несе в собі ознаки ритуалу, як, наприклад, церемонія інавгурації президента);

- c символ-об 'єкт (прапори, емблеми, символічні пам'ятки тощо);

- символ-персона (історичні діячі, науковці, письменники, правителі; також це можуть бути національні герої чи спортсмени, переможці великих змагань; у політичному контексті це, в першу чергу, засновники течій, ідеологій, партій, харизматичні політичні діячі та ін.);

символ-звук (гімн, слогани, музичні твори (зокрема народні пісні), які безпомилково впізнаються громадянами, викликають здебільшого позитивні емоції й асоціюються переважно зі значущими (історичними) подіями).

У перехідні періоди спостерігається «хаос символів» різних вимірів суспільного буття. При цьому комеморативні практики слугують не лише консолідаційним чинником. Перебуваючи в ситуації перманентного дефіциту ідей та символів, сучасна соціальна реальність знаходить підживлення саме в колективній пам'яті. «Робота пам'яті» - своєрідна соціокультурна компенсація, яка допомагає соціуму й індивіду виробляти власне усвідомлене ставлення до 
минувшини, культурних i моральних традицій народу i водночас уникати травмуючого впливу повсякденності. Пам'ять стала також засобом мобілізації політичної влади в формуванні та закріпленні цінностей, національних символів, знань про минуле (Савельева, Полетаев, 2004: 20).

В умовах сучасних трансформаційних зламів українського суспільства спостерігаються розриви зв'язків, переосмислення ціннісних ідентитетів, складність адаптування до культурних змін, плюралізація потрактувань подій минулого, тощо. У «розділених суспільствах» (divided societies), як зауважує сучасний американський дослідник М. Росс, символічна форма виразу смислу одночасно працює як бар'єр або можливість щодо здійснення людиною вибору, усвідомлення власної ідентичності на всіх їі рівнях - від етнічної до культурної i політичної, уможливлює судження, i одночасно є критерієм ступеню напруги у певному суспільстві (Ross, 2009: 4). У цьому контексті акт комеморації, що визначається політикою пам'яті, може увиразнитися i як консолідуючий, i як дезінтегруючий чинник. Відтак варто враховувати сталу амбівалентність, характерну для колективної пам'яті українців: співіснування на рівні колективних уявлень кількох відмінних проекцій трактування української історії. Перша проекція сформована переважно у націоцентричній історичній парадигмі, друга - під впливом імперсько-радянських історичних доктрин та сформованих на їх основі міфів. Контраверсійність, а часом і несумісність ціннісно-смислових оцінок історичних подій i постатей, надмірна політизованість цього сегмента суспільної свідомості є джерелом соціальної напруги, чинником дезінтеграції національної спільноти (Воропаєва, 2011: 15).

Висновки. Отже, національна ідентичність має соціокультурні складові, які $\epsilon$ не менш важливими, ніж політичні та соціально-економічні. Зокрема йдеться про колективні уявлення про минуле. Образ минулого є колективним конструктом, параметри якого форматуються владними відносинами в соціумі. Поява спільноти забезпечується спільним минулим, культурним спадком, суб'єктивним переживанням єдності на основі спільних цілей або ж певних (зокрема й зовнішніх) ознак. Її тривкість та моральна значимість забезпечується спільними спогадами та культурними символами, які поступово перетворюються на символи колективної ідентичності. Знаково, що суспільні та культурні пріоритети, а також моделі національної ідентичності проектуються 3 огляду на тривале перебування українського соціуму в історично-часовій «зоні розриву» й критичній точці дискретності соціокультурного простору.

Колективні ідентичності, зокрема національна ідентичність, не $\epsilon$ іманентно притаманними феноменами: вони формуються й видозмінюються під впливом різноманітних політичних, економічних і соціокультурних чинників, супроводжуються корекцією ціннісних i світоглядних настанов, розвитком знакових і смислових систем, зрушеннями на осі координат «свій-чужийспіввітчизник» тощо; увиразненням характериних структурних кодів як асоціативних полів надтекстової орієнтації. Комеморації є формою об'єктивації культурної пам'яті - відновленням пам'яті в іiі речових репрезентаціях (М. Фуко), одним з інструментів реалізації політики пам’яті та конструювання ідентичності. 
Ідентифікація колективна / національна увиразнюється через єдність мотивації, суголосності морально-етичних принципів та норм, співпереживання, усвідомлення спільних кодів пам'яті тощо. Обумовлена політико-соціальним й культурним контекстом, національна ідентичність оприявнюється через ідентифікацію, яка, в свою чергу, залежить від свідомого вибору спільноти та окремої особи і керується суб'єктивними ідентитетами (усвідомлення спільного минулого, історичної долі, національна свідомість і національний характер, спільні цінності, притаманні спільноті тощо).

\section{СПИСОК ВИКОРИСТАНИХ ДЖЕРЕЛ І ЛІТЕРАТУРИ}

Андерсон, 2001 - Андерсон Б. Воображаемые сообщества. Размышления об истоках и распространении национализма. М. : Канон-пресс, 2001. 288 с.

Ассман, 2012 - Ассман А. Простори спогаду. Форми та трансформації культурної пам'яті / пер. 3 нім. К. Дмитренко, Л. Доронічева, О. Юдін. К.: Ніка-Центр, 2012. 440 с. (Серія «Зміна парадигми». Вип. 15).

Ассман, 2014 - Ассман А. Длинная тень прошлого. Мемориальная культура и историческая политика / пер. с нем. Б. Хлебникова. М.: Новое литературное обозрение, 2014. 323 с.

Брубейкер, 2012 - Брубейкер Р. Этничность без групп. М.: Издательский дом Высшей школы экономики, 2012. $408 \mathrm{c.}$

Брюбейкер, 2006 - Брюбейкер Р. Переобрамлений націоналізм. Статус нації та національне питання в новій Європі; пер. з англ. Львів : Кальварія, 2006. 280 с.

Вагнер-Пацифи, Шварц, 2011 - Вагнер-Пацифи Р., Шварц Б. Мемориал ветеранов Вьетнама: памяти трудного пришлого // Политическая конщептология. 2011. № 2. С. 155-192.

Васильев, 2009 - Васильев А.Г. Мемориализация и забвение как механизмы производства культурного единства и разнообразия // Фундаментальные проблемы культурологи. T. VI. Культурное наследие: от прошлого к будущему / отв. ред. Д.Л. Спивак М., Спб.: Новый хронограф, Эйдос, 2009. С. 56-68.

Воропаєва, 2011 - Воропаєва Т.С. Формування національної і європейської ідентичності громадян України: теоретико-емпіричні аспекти (1993-2010 роки). // Наукові студії із соиіальної та політичної психології. 2011. Вип. 26. С. 333-343. URL: http://nbuv.gov.ua/UJRN/Nsspp_2011_26_40

Гібернау, 2012 - Гібернау М. Ідентичність націй / пер. з англ. П. Таращука; ред. Л. Марченко. К.: Темпора, 2012. $303 \mathrm{c}$.

Гузьман, Саппа, 2016 - Гузьман О.А., Саппа Г-М.М. Національна ідентичність як соціокультурний феномен // Virtus: Scientific Journal / Editor-in-Chief M.A. Zhurba. 2016. Juni (№ 8). P. 64-68.

Дюркгейм, 1998 - Дюркгейм Э. Элементарные формы религиозной жизни // Мистика. Религия. Наука. Классики мирового религиоведения: антология / пер. с англ., нем., фр., сост. и общ. ред. А. Н. Красникова. М.: Канон+, 1998. С. 174-231.

Зарецкий, 2008 - Зарецкий Ю. История, память, национальная идентичность // Неприкосновенный запас. 2008. № 3(59). URL: http://magazines.russ.ru/nz/2008/3/za4-pr.html\#_ftnref28

Зиновьев, 2008 - Зиновьев А. Символы российской национально-государственной идентичности // Experimentum, 2009: Сборник научных статей философского факультета МГУ / Под ред. А. Селезнева, Е. Мощелкова; Сост. А. Воробьев, Т. Денисова. М.: Издатель Воробьёв А.В., 2008.

Йейтс, 1997 - Йейтс Ф.А. Искусство памяти; [Пер. с англ.] СПб.: Университетская книга, 1997. 480 с.

Касториадис, 2003 - Касториадис К. Воображаемое установление общества. М.: Логос, 2003. 480 с.

Касьянов, 2016 - Касьянов Г.В. Історична пам'ять та історична політика: до питання про термінологію й генеалогію понять // Украӥнський історичний журнал. 2016. № 2(527). С. 118-137.

Киридон, 2016 - Киридон А.М. Гетеротопії пам'яті:. Теоретико-методологічні проблеми студій пам'яті. Київ: Ніка-Центр, 2016. 320 с.

Козеллек, 2005 - Козеллек Р. Минуле майбутнє. Про семантику історичного часу. К. : Дух і літера, 2005. 317 с.

Козеллек, 2006 - Козеллек Р. Часові пласти. Дослідження з теорії історії; [Пер. з нім.]. К.: Дух і літера, 2006. $436 \mathrm{c}$.

Коник, 2009 - Коник А. «Історична пам'ять» та «політика пам'яті» в епоху медіа культури // Вісник Львівського національного університету ім. І. Франка. Серія «журналістика». 2009. Вип. 32. С. 153-163.

Коннертон, 2004 - Коннертон П. Як суспільства пам'ятають / пер. $з$ англ., наук. ред. Світлани Шліпченко. К.: Ніка-центр. 2004. 184 с. (Серія «Зміна парадигми». Вип. 7).

Коноваленко, 2005 -Коноваленко А.В. Психология политической рекламы. Ростов н/Д: Феникс, 2005. (Серия «Психологический практикум»). 96 с.

Копосов, 2011 - Копосов Н.Е. Память строгого режима. История и политика в России. М.: Новое литературное обозрение, 2011. 320 с. 
Кривда, 2019 - Кривда Н. Колективна пам'ять як чинник формування групової ідентичності // Філософські обріï. 2019. № 41. С. 60-76.

Лотман, 1992 - Лотман Ю. Символ в системе культуры // Избранные статьи. Таллинн, 1992. Т. 1. С. $191-199$. Майноут, 2000 - Майноут К. Анатомія націоналізму // Націоналізм. Антологія. К.: Смолоскип, 2000. С. 255256.

Малинова, 2017 - Малинова О.Ю. Коммеморация исторических событий как инструмент символической политики: Возможности сравнительного анализа // Полития. 2017. № 4 (87). С. 6-11.

Малинова, 2018 - Малинова О.Ю. Коммеморация столетия революции(й) 1917 года в РФ: анализ стратегий ключевых мнемонических акторов // Полис. Политические исследования. 2018. № 1. С. 9-25.

Мегилл, 2007 - Мегилл А. Историческая зпистемология / Перевод Кукарцевой М., Кащаева В., Тимонина В. М.: «Канон+»; РООИ «Реабилитация», 2007. 480 с.

Нагорна, 2005 - Нагорна Л. Ідентичність національна // Енциклопедія історії України: Т. 3: Е-Й / Редкол.: В.А. Смолій (голова) та ін. НАН України. Інститут історії України. К.: В-во «Наукова думка», 2005. С. $415-417$. Нагорна, 2011 - Нагорна Л. Соціокультурна ідентичність: пастки ціннісних розмежувань. К.: ІПіЕНД НАНУ, 2011. 272 c.

Нечитайло, 2014 - Нечитайло А.А. Націєтворення та національна пам’ять в епоху постмодерну та розбудови глобального інформаційного суспільства // Політологічний вісник. 2014. Вип. 74. С. 332-340.

Нора, 1998 - Нора П. Поколение как место памяти // Новое литературное обозрение. 1998 № 30. URL:http://magazines.russ.ru/ authors/n/nora/

Нора та ін., 1999 - Нора П., Озуф М., Ж. де Пюимеж, Винок М. Франция — память. Спб. : Новая Петербургская библиотека, Изд. С-Пб. университета. 1999. 328 с.

Нора, 2005 - Нора П. Всемирное торжество памяти // Неприкосновенный запас. 2005. № 2-3 (40-41). URL: http://magazines.russ.ru/nz/2005/2/ ha2.html

Пташник-Сердюк, 2012 - Пташник-Сердюк О.І. Соціологічний аналіз процесу ідентифікації // Наукові праці. Соиіологія. 2012. Вип. 189. Т. 201. С. 60-64.

Ренан, 2006 - Ренан Е. Що таке нація? // Націоналізм: Антологія / Упоряд. О. Проценко, В. Лісовий. 2-ге вид. К.: Смолоскип, 2006. С. 107-120.

Рикёр, 2004 - Рикёр П. Память, история, забвение / Пер. с фр. М.: Изд-во гуманитарной лит-ры, 2004.728 с.

Романовская, Фоменко, 2015 - Романовская Е.В., Фоменко Н.Л. Идентичность и коммеморация // Власть. 2015. № 7. C. 81-84.

Рюзен ,2010 - Рюзен Й. Нові шляхи історичного мислення / Переклав з нім. В. Кам'янець. Львів: Літопис, 2010. 358 c.

Савельева, Полетаев, 2004 - Савельева И., Полетаев А. Социальные представления о прошлом: типы и механизмы формирования // Гуманитарные исследования. М.: ГУ-ВШЭ, 2004. Вып. 7 (14). 52 с.

Савицька, 2014 - Савицька I.М. Формування національної ідентичності через призму історичної пам'яті // Науковий вісник Національного університету біоресурсів і природокористування України, 2014, Вип. 203, ч. 1.C.14-20.

Сміт, 1994 - Сміт Е. Національна ідентичність. / пер. з англ. П. Таращук. К.: Основи, 1994. 196 с.

Сміт, 2013 - Сміт Е. Нації і націоналізм у глобальну епоху. К.: Ніка-Центр, 2013. 278 с.

Смолина, 2015 - Смолина Н.С. Современные операции-трансформации с коллективной памятью: социальные рамки действительности // Дні науки філософського факультету - 2014: Міжн. наук. конф. (15-16 квіт. 2014 р., Київ): [матеріали доповідей та виступів] / редкол.: А.С. Конверський [та ін.]. К.: Видавничо-поліграфічний центр «Київський університет», 2014. Ч. 5. С. 120.

Смоляр, 2009 - Смоляр А. Пам'ять та політика [пер. 3 польськ. ] // Україна Модерна. Вип. 4 (15): Пам'ять як поле змагань / Гол. ред. Я. Грицак К.: Критика, 2009. С. 78-94.

Стасевська, 2018 - Стасевська О.А. Експлікація аксіологічного аспекту концепту «історична пам’ять» // Вiсник Національного університету «Юрдична академія України імені Ярослава Мудрого». 2018. Вип 1 (36). С. 123135.

Степико, 2011 - Степико М.Т. Українська ідентичність: феномен і засади формування. К.: НІСД, 2011.336 с.

Тарасова, 2017 - Тарасова Н.Ю. Комеморативні засади національної ідентифікаці // Актуальні проблеми філософії та соичіологіï. 2017. № 20. С. 140-143.

Україна, 2007 - Україна в 2006 році: внутрішнє і зовнішнє становище та перспективи розвитку: експертна доповідь / ред. В.І. Тищенко. К. : Славутич-Дельфін, 2007. 256 с.

Філософський словник, 2002 - Філософський енциклопедичний словник : енциклопедія / НАН України, Ін-т філософії ім. Г.С. Сковороди ; голов. ред. В.І. Шинкарук. Київ : Абрис, 2002. 742 с.

Хальбвакс, 2007 - Хальбвакс М. Социальные рамки памяти. М. : Новое изд-во, 2007. 384 с.

Хаттон, 2004 - Хаттон П. История как искусство памяти / пер. с англ. В.Ю. Быстрова. СПб: Владимир Даль, 2004. 424 c.

Шацька, 2011 - Шацька Б. Минуле - пам’ять - міт / Пер. 3 пол. Олесь Герасим, наук. ред. Андрій Павлишин. Чернівці: Книги. XXI, 2011. 248 с.

Як, 2017 - Як Б. Национализм и моральная психология сообщества. М.: Изд-во Института Гайдара, 2017.520 с. Le Goff J, 1988 - Le Goff J. Histoire et memoire. Paris, Gallimard, 1988. 416 p. 
Nora, 1994 - Nora P. Between memory and history: Les lieux de memoire. N.Y., Oxford: Oxford univ. press, 1994. 724 p.

Ross, 2009 - Ross M.H. Culture and Belonging in Divided Societies: Contestation and Symbolic Landscapes. Philadelphia : University of Pennsylvania Press, 2009. 312 p.

\section{REFERENCES}

Anderson, 2001 - Anderson B. Voobrazhaemыe soobshchestva. Razmыshlenyia ob ystokakh y rasprostranenyy natsyonalyzma [Imaginary communities. Reflections on the origins and spread of nationalism]. M. : Kanon-press, 2001. 288 s. [in Russian]

Assman, 2012 - Assman A. Prostory spohadu. Formy ta transformatsii kulturnoi pam'iati [Spaces of memory . Forms and transformations of cultural memory] / per. z nim. K. Dmytrenko, L. Doronicheva, O. Yudin. K.: Nika-Tsentr, 2012. 440 s. (Seriia «Zmina paradyhmy». Vyp. 15). [in Ukrainian]

Assman, 2014 - Assman A. Dlynnaia ten proshloho. Memoryalnaia kultura y ystorycheskaia polytyka [Long shadow of the past. Memorial culture and historical politics] / per. s nem. B. Khlebnykova. M.: Novoe lyteraturnoe obozrenye, 2014. 323 s. [in Russian]

Brubeiker, 2012 - Brubeiker R. Эtnychnost bez hrupp [Ethnicity without groups]. M.: Yzdatelskyi dom Vsshei shkolы эkonomyky, 2012. 408 s. [in Russian]

Briubeiker, 2006 - Briubeiker R. Pereobramlenyi natsionalizm. Status natsii ta natsionalne pytannia v novii Yevropi [Perebramlennyi natsionalizm [Text]: status of the nation and the national question in the new Europe] / Per. $\mathrm{z}$ anhl. Lviv : Kalvariia, 2006. 280 s. [in Ukrainian]

Vahner-Patsyfy, Shvarts, 2011 - Vahner-Patsyfy R., Shvarts B. Memoryal veteranov Vetnama: pamiaty trudnoho pryshloho [Vietnam Veterans Memorial: Commemorating a Difficult Newcomer] // Polytycheskaia kontseptolohyia. 2011. № 2. S. 155-192. [in Russian]

Vasylev, 2009 - Vasylev A.H. Memoryalyzatsyia y zabvenye kak mekhanyzmы proyzvodstva kulturnoho edynstva y raznoobrazyia [Memorialization and oblivion as mechanisms for the production of cultural unity and diversity] // Fundamentalnble problembl kulturolohy. T. VI. Kulturnoe nasledye: ot proshloho k budushchemu / otv. red. D.L. Spyvak M., Spb.: Novыi khronohraf, Эidos, 2009. C. 56-68. [in Russian]

Voropaieva, 2011 - Voropaieva T.S. Formuvannia natsionalnoi i yevropeiskoi identychnosti hromadian Ukrainy: teoretyko-empirychni aspekty (1993-2010 roky) [Formation of national and European identity of citizens of Ukraine: theoretical and empirical aspects (1993-2010)]. // Naukovi studii iz sotsialnoi ta politychnoi psykholohii. 2011. Vyp. 26. S. 333-343. URL: http://nbuv.gov.ua/UJRN/Nsspp_2011_26_40. [in Ukrainian]

Hibernau, 2012 - Hibernau M. Identychnist natsii [Identity of Nations] / per. z anhl. P. Tarashchuka; red. L. Marchenko. K.: Tempora, 2012. 303 s. [in Ukrainian]

Huzman, Sappa, 2016 - Huzman O.A., Sappa H-M.M. Natsionalna identychnist yak sotsiokulturnyi fenomen [National identity as a socio-cultural phenomenon] // Virtus: Scientific Journal / Editor-in-Chief M.A. Zhurba. 2016. Juni (№ 8). S. 64-68. [in Ukrainian]

Diurkheim, 1998 - Diurkheim E. Elementarnыe formy relyhyoznoi zhyzny [Elementary forms of religious life] // Mystyka. Relyhyia. Nauka. Klassyky myrovoho relyhyovedenyia: antolohyia / per. s anhl., nem., fr., sost. y obshch. red. A.N. Krasnykova. M.: Kanon+, 1998. S. 174-231. [in Russian]

Zaretskyi, 2008 - Zaretskyi Yu. Ystoryia, pamiat, natsyonalnaia ydentychnost [History, memory, national identity] // Neprykosnovennbii zapas. 2008. № 3(59). URL: http://magazines.russ.ru/nz/2008/3/za4-pr.html\#_ftnref28 [in Russian] Zynovev, 2008 - Zynovev A. Symvoly rossyiskoi natsyonalno-hosudarstvennoi ydentychnosty [Symbols of Russian national-state identity] // Experimentum, 2009: Sbornyk nauchnblkh statei fylosofskoho fakulteta MHU / Pod red. A. Selezneva, E. Moshchelkova; Sost. A. Vorobev, T. Denysova. M.: Yzdatel Vorobëv A.V., 2008. [in Russian]

Yeits, 1997 - Yeits F.A. Yskusstvo pamiaty [The art of memory]; [Per. s anhl.] SPb.: Unyversytetskaia knyha, 1997. 480 s. [in Russian]

Kastoryadys, 2003 - Kastoryadys K. Voobrazhaemoe ustanovlenye obshchestva [The Imaginary Establishment of Society]. M.: Lohos, 2003. 480 s. [in Russian]

Kasianov, 2016 - Kasianov H.V. Istorychna pamiat ta istorychna polityka: do pytannia pro terminolohiiu y henealohiiu poniat [Historical memory and historical politics: on the question of terminology and genealogy of concepts] // Ukrainskyi istorychnyi zhurnal. 2016. № 2(527). S. 118-137. [in Ukrainian]

Kyrydon, 2016 - Kyrydon A.M. Heterotopii pam'iati:. Teoretyko-metodolohichni problemy studii pam'iati [Heterotopias of memory :. Theoretical and methodological problems of memory studies]. Kyiv : Nika-Tsentr, 2016. 320 s. [in Ukrainian]

Kozellek, 2005 - Kozellek R. Mynule maibutnie. Pro semantyku istorychnoho chasu [Past future. On the semantics of historical time]. K. : Dukh i litera, 2005. 317 s. [in Ukrainian]

Kozellek, 2006 - Kozellek R. Chasovi plasty. Doslidzhennia z teorii istorii [Temporal layers and. Research in the theory of history]; [Per. z nim.]. K.: Dukh i litera, 2006. 436 s. [in Ukrainian]

Konyk, 2009 - Konyk A. «Istorychna pam'iat» ta «polityka pam'iati» v epokhu media kultury [Historical memory and the politics of memory in a media-cultural epoch] // Visnyk Lvivskoho natsionalnoho universytetu im. I. Franka. Seriia «zhurnalistyka». 2009. Vyp. 32. S. 153-163. [in Ukrainian] 
Konnerton, 2004 - Konnerton P. Yak suspilstva pam'iataiut [As societies remember] / per. z anhl., nauk. red. Svitlany Shlipchenko. K.: Nika-tsentr. 2004. 184 s. (Seriia «Zmina paradyhmy». Vyp. 7). [in Ukrainian]

Konovalenko, 2005 -Konovalenko A.V. Psykholohyia polytycheskoi reklamy [The psychology of political advertising]. Rostov n/D: Fenyks, 2005. (Seryia «Psykholohycheskyi praktykum»). 96 s. [in Russian]

Koposov, 2011 - Koposov N.E. Pamiat strohoho rezhyma. Ystoryia y polytyka v Rossyy [Strict mode memory. History and politics in Russia]. M.: Novoe lyteraturnoe obozrenye, 2011. 320 s. [in Russian]

Kryvda, 2019 - Kryvda N. Kolektyvna pam'iat yak chynnyk formuvannia hrupovoi identychnosti [Collective memory as a factor in the formation of group identity] // Filosofski obrii. 2019. № 41. S. 60-76. [in Ukrainian]

Lotman, 1992 - Lotman Yu. Symvol v systeme kultury [Symbol in the system of culture] // Yzbrannble staty. Tallynn, 1992. T. 1. S. 191-199. [in Russian]

Mainout, 2000 - Mainout K. Anatomiia natsionalizmu [Anatomy of nationalism] // Natsionalizm. Antolohiia. K.: Smoloskyp, 2000. S. 255-256. [in Ukrainian]

Malynova, 2017 - Malynova O.Yu. Kommemoratsyia ystorycheskykh sobytyi kak ynstrument symvolycheskoi polytyky: Vozmozhnosty sravnytelnoho analyza [Commemorating Historical Events as a Tool of Symbolic Politics: Possibilities for Comparative Analysis] // Polytyia. 2017. № 4 (87). S. 6-11. [in Russian]

Malynova, 2018 - Malynova O.Yu. Kommemoratsyia stoletyia revoliutsyy(i) 1917 hoda v RF: analyz stratehyi kliuchevykh mnemonycheskykh aktorov [Commemoration of the centenary of the revolution (s) of 1917 in the Russian Federation: analysis of the strategies of key mnemonic actors] // Polys. Polytycheskye yssledovanyia. 2018. № 1. S. 925. [in Russian]

Mehyll, 2007 - Mehyll A. Ystorycheskaia epystemolohyia [Historical epistemology] / Perevod Kukartsevoi M., Kashchaeva V., Tymonyna V. M.: «Kanon+»; ROOY «Reabylytatsyia», 2007. 480 s. [in Russian]

Nahorna, 2005 - Nahorna L. Identychnist natsionalna [National identity] // Entsyklopediia istorii Ukrainy: T. 3: E-I / Redkol.: V.A. Smolii (holova) ta in. NAN Ukrainy. Instytut istorii Ukrainy. K.: V-vo «Naukova dumka», 2005. S. 415417. [in Ukrainian]

Nahorna, 2011 - Nahorna L. Sotsiokulturna identychnist: pastky tsinnisnykh rozmezhuvan [Sociocultural identity : traps of value demarcations]. K.: IPiEND NANU, 2011. 272 s. [in Ukrainian]

Nechytailo, 2014 - Nechytailo A.A. Natsiietvorennia ta natsionalna pam'iat $v$ epokhu postmodernu ta rozbudovy hlobalnoho informatsiinoho suspilstva [Nation-building and national memory in the postmodern era and the development of the global information society] // Politolohichnyi visnyk. 2014. Vyp. 74. S. 332-340. [in Ukrainian] Nora, 1998 - Nora P. Pokolenye kak mesto pamiaty [Generation as a place of memory] // Novoe lyteraturnoe obozrenye. 1998 № 30. URL:http://magazines.russ.ru/ authors/n/nora/ [in Russian]

Nora ta in., 1999 - Nora P., Ozuf M., Zh. De Piuymezh, Vynok M. Frantsyia — pamiat [France — memory]. Spb. : Novaia Peterburhskaia byblyoteka, Yzd. S-Pb. unyversyteta. 1999. 328 s. [in Russian]

Nora, 2005 - Nora P. Vsemyrnoe torzhestvo pamiaty [World commemoration] // Neprykosnovennbli zapas. 2005. № 23 (40-41). URL: http://magazines.russ.ru/nz/2005/2/ ha2.html. [in Russian]

Ptashnyk-Serdiuk, 2012 - Ptashnyk-Serdiuk O.I. Sotsiolohichnyi analiz protsesu identyfikatsii [Sociological analysis of the identification process] // Naukovi pratsi. Sotsiolohiia. 2012. Vyp. 189. T. 201. S. 60-64. [in Ukrainian]

Renan, 2006 - Renan E. Shcho take natsiia? [What is a nation?] // Natsionalizm: Antolohiia / Uporiad. O. Protsenko, V. Lisovyi. 2-he vyd. K.: Smoloskyp, 2006. S. 107-120. [in Ukrainian]

Rykër, 2004 - Rykër P. Pamiat, ystoryia, zabvenye [Memory, history, oblivion] / Per. s fr. M.: Yzd-vo humanytarnoi lyt-ry, 2004. 728 s. [in Russian]

Romanovskaia, Fomenko, 2015 - Romanovskaia E.V., Fomenko N.L. Ydentychnost y kommemoratsyia [Identity and commemoration] // Vlast. 2015. № 7. S. 81-84. [in Russian]

Riuzen ,2010 - Riuzen Y. Novi shliakhy istorychnoho myslennia [New ways of historical thinking] / Pereklav z nim. V. Kam'ianets. Lviv: Litopys, 2010. 358 s. [in Ukrainian]

Saveleva, Poletaev, 2004 - Saveleva Y., Poletaev A. Sotsyalnye predstavlenyia o proshlom: typy y mekhanyzmy formyrovanyia [Social views of the past: types and mechanisms of formation] // Humanytarnye yssledovanyia. M.: HUVShE, 2004. Vyp. 7 (14). 52 s. [in Russian]

Savytska, 2014 - Savytsk I.M. Formuvannia natsionalnoi identychnosti cherez pryzmu istorychnoi pamiati [Problems of formation national identity through the prism of historical Memory in modern society] // Naukovyi visnyk Natsionalnoho universytetu bioresursiv $i$ pryrodokorystuvannia Ukrainy, 2014, Vyp. 203, ch. 1. S. 14-20. [in Ukrainian]

Smit, 1994 - Smit E. Natsionalna identychnist [National identity] / per. z anhl. P. Tarashchuk. K.: Osnovy, 1994.196 s. [in Ukrainian]

Smit, 2013 - Smit E. Natsii i natsionalizm u hlobalnu epokhu [Nations and nationalism in the global era]. K.: NikaTsentr, 2013. 278 s. [in Ukrainian]

Smolyna, 2015 - Smolyna N.S. Sovremennыe operatsyy-transformatsyy s kollektyvnoi pamiatiu: sotsyalnыe ramky deistvytelnosty [Modern transformation operations with collective memory: the social framework of reality] // Dni nauky filosofskoho fakultetu - 2014: Mizhn. nauk. konf. (15-16 kvit. 2014 r., Kyiv): [materialy dopovidei ta vystupiv] I redkol.: A.Ye. Konverskyi [ta in.]. K.: Vydavnycho-polihrafichnyi tsentr «Kyivskyi universytet», 2014. Ch. 5. S. 120. [in Russian]

Smoliar, 2009 - Smoliar A. Pam'iat ta polityka [Memory and Politics] [per. z polsk] // Ukraina Moderna. Vyp. 4 (15): Pam'iat yak pole zmahan / Hol. red. Ya. Hrytsak K.: Krytyka, 2009. S. 78-94. [in Ukrainian] 
Stasevska, 2018 - Stasevska O.A. Eksplikatsiia aksiolohichnoho aspektu kontseptu «istorychna pam'iat» [Explication of the axiological aspect of the concept«historical memory»] // Visnyk Natsionalnoho universytetu "Iurdychna akademiia Ukrainy imeni Yaroslava Mudroho». 2018. Vyp. 1 (36). S. 123-135. [in Ukrainian]

Stepyko, 2011 - Stepyko M.T. Ukrainska identychnist: fenomen i zasady formuvannia [Ukrainian identity: phenomenon and principles of formation]. K.: NISD, 2011.336 s. [in Ukrainian]

Tarasova, 2017 - Tarasova N.Yu. Komemoratyvni zasady natsionalnoi identyfikatsi [Commemorative grounds for national identification] // Aktualni problemy filosofii ta sotsiolohii. 2017. № 20. S. 140-143. [in Ukrainian]

Ukraina, 2007 - Ukraina v 2006 rotsi: vnutrishnie i zovnishnie stanovyshche ta perspektyvy rozvytku: ekspertna dopovid [Ukraine in 2006 : internal and external situation and development prospects: expert report.] / red. V.I. Tyshchenko. K. : Slavutych-Delfin, 2007. 256 s. [in Ukrainian]

Filosofskyi slovnyk, 2002 - Filosofskyi entsyklopedychnyi slovnyk : эntsyklopedyia [Philosophical Encyclopedic Dictionary] / NAN Ukrainy, In-t filosofii im. H.S. Skovorody ; holov. red. V.I. Shynkaruk. Kyiv : Abrys, 2002.742 s. [in Ukrainian]

Khalbvaks, 2007 - Khalbvaks M. Sotsyalnыe ramky pamiaty [Social framework of memory]. M. : Novoe yzd-vo, 2007. 384 s. [in Russian]

Khatton, 2004 - Khatton P. Ystoryia kak yskusstvo pamiaty [History as an art of memory] / per. s anhl. V.Yu. Bystrova. SPb: Vladymyr Dal, 2004. 424 s. [in Russian]

Shatska, 2011 - Shatska B. Mynule - pam'iat - mit [Past - memory - myth] / Per. z pol. Oles Herasym, nauk. red. Andrii Pavlyshyn. Chernivtsi: Knyhy. KhKhI, 2011. 248 s. [in Ukrainian]

Yak, 2017 - Yak B. Natsyonalyzm y moralnaia psykholohyia soobshchestva [Nationalism and the moral psychology of the community]. M.: Yzd-vo Ynstytuta Haidara, 2017. 520 s. [in Russian]

Le Goff J, 1988 - Le Goff J. Histoire et memoire. Paris, Gallimard, 1988. 416 p. [in French]

Nora, 1994 - Nora P. Between memory and history: Les lieux de memoire. N.Y., Oxford: Oxford univ. press, 1994. 724 p. [in English]

Ross, 2009 - Ross M.H. Culture and Belonging in Divided Societies: Contestation and Symbolic Landscapes. Philadelphia : University of Pennsylvania Press, 2009. 312 p. [in English]

УДК $316.334 .56(470+571) " 18 / 19 ": 930$

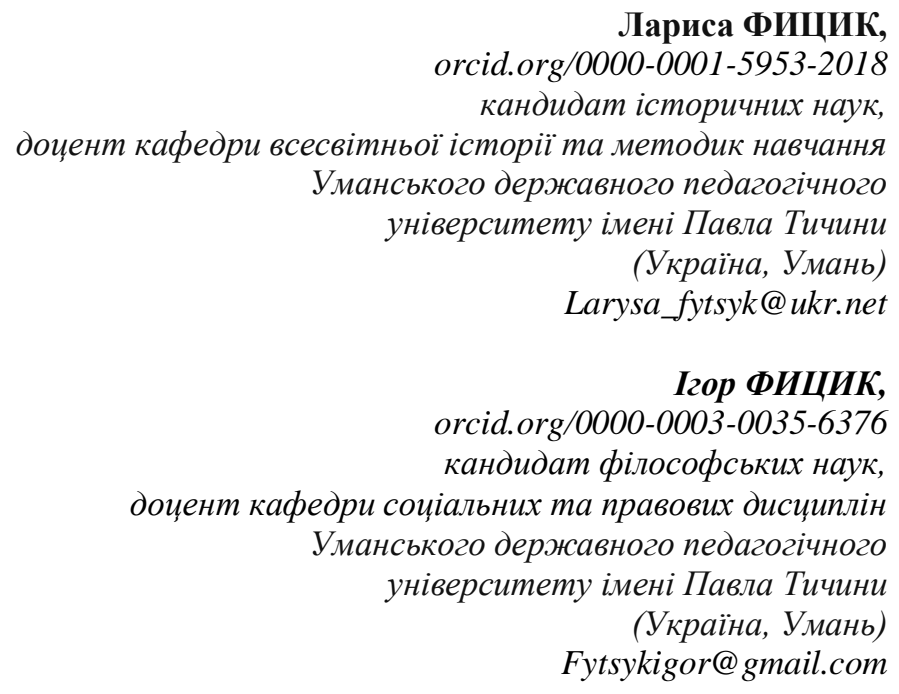

\section{СОЦІОКУЛЬТУРНИЙ ПРОСТІР РОСІЙСЬКОГО МІСТА (ДРУГА ПОЛОВИНА ХІХ - ПОЧАТОК ХХ СТ.): ІСТОРІОГРАФІЯ ПРОБЛЕМИ}

У статті за допомогою комплексного, системного підходу висвітлюється стан вивчення сочіокультурного простору російського міста другої половини XIX - початку XX ст. в російській історіографії. Здійснено неупереджений аналіз накопиченого доробку дореволюиійних, радянських та сучасних російських істориків, який стосувався як вивчення окремих складових соиіокультурного простору російського міста зазначеного періоду, так і трактування його соціокультурного образу. Виокремлено основні групи праць з історіографії проблеми та встановлено персональний внесок їх авторів у ї̈ розробку. Виявлено, що у дореволюиійній та радянській історіографії соиіально-культурні проблеми російського міста не належали до 